\title{
OCEAN DRILLING PROGRAM
}

\section{LEG 177 PRELIMINARY REPORT}

\section{SOUTHERN OCEAN PALEOCEANOGRAPHY}

\author{
Dr. Rainer Gersonde \\ Co-Chief Scientist \\ Alfred Wegener Institut \\ für Polar und Meeresforschung \\ Postfach 120161 \\ D-27515 Bremerhaven \\ Germany
}

\author{
Dr. David Hodell \\ Co-Chief Scientist \\ Department of Geology \\ University of Florida \\ 1112 Turlington Hall \\ Gainesville, Florida 32611 \\ U.S.A.
}

\author{
Dr. Peter Blum \\ Staff Scientist \\ Ocean Drilling Program \\ Texas A\&M University Research Park \\ 1000 Discovery Drive \\ College Station, Texas 77845-9547 \\ U.S.A.
}

Jack Baldauf

Deputy Director

of Science Operations

ODP/TAMU
Peter Blum

Leg Project Manager

Science Services

ODP/TAMU

April 1998 
This informal report was prepared from the shipboard files by the scientists who participated in the cruise. The report was assembled under time constraints and is not considered to be a formal publication which incorporates final works or conclusions of the participating scientists. The material contained herein is privileged proprietary information and cannot be used for publication or quotation.

\section{Preliminary Report No. 77}

First Printing 1998

Distribution

\section{$\underline{D} \underline{I} \underline{\mathrm{S}} \underline{\mathrm{C}} \underline{\mathrm{L}} \underline{\mathrm{A}} \underline{\mathrm{I}} \underline{\mathrm{M}} \underline{\mathrm{E}} \underline{\mathrm{R}}$}

This publication was prepared by the Ocean Drilling Program, Texas A\&M University, as an account of work performed under the international Ocean Drilling Program, which is managed by Joint Oceanographic Institutions, Inc., under contract with the National Science Foundation. Funding for the program is provided by the following agencies:

Australia/Canada/Chinese Taipei/Korea Consortium for Ocean Drilling Deutsche Forschungsgemeinschaft (Federal Republic of Germany)

Institut Français de Recherche pour l'Exploitation de la Mer (France)

Ocean Research Institute of the University of Tokyo (Japan)

National Science Foundation (United States)

Natural Environment Research Council (United Kingdom)

European Science Foundation Consortium for the Ocean Drilling Program (Belgium,

Denmark, Finland, Iceland, Italy, The Netherlands, Norway, Portugal, Spain, Sweden, Switzerland, and Turkey)

People's Republic of China

Any opinions, findings and conclusions, or recommendations expressed in this publication are those of the author(s) and do not necessarily reflect the views of the National Science Foundation, the participating agencies, Joint Oceanographic Institutions, Inc., Texas A\&M University, or Texas A\&M Research Foundation. 
Leg 177

Preliminary Report

Page 3

The following scientists were aboard the JOIDES Resolution for Leg 177 of the Ocean Drilling Program:

Co-Chief

Rainer E. Gersonde

Alfred-Wegener-Institut für Polar und Meeresforschung

Postfach 120161

Columbusstraße 2

Bremerhaven 27515

Federal Republic of Germany

Internet: rgersonde@awi-bremerhaven.de

Work: (49) 471-483-1203

Fax: (49) 471-483-1149

\section{Co-Chief}

David A. Hodell

Department of Geology

University of Florida

1112 Turlington Hall

Gainesville, FL 32611

U.S.A.

Internet: hodell@nersp.nerdc.ufl.edu

Work: (352) 392-6137

Fax: (352) 392-9294

Staff Scientist

Peter Blum

Ocean Drilling Program

Texas A\&M University

1000 Discovery Drive

College Station, TX 77845-9547

U.S.A.

Internet: peter_blum@odp.tamu.edu

Work: (409) 845-9299

Fax: (409) 845-0876

Paleontologist (Foraminifer)

E. Carin Andersson

Geologisk Instituit

Universitetet i Bergen

Allégaten 41

Bergen 5007

Norway

Internet: carin.andersson@geol.uib.no

Work: (47) 5558-3535

Fax: (47) 5558-9416

Paleontologist (Foraminifer)

William E. N. Austin

Department of Geography

University of Durham

Environmental Research Centre

South Road
Durham DH1 3LE

United Kingdom

Internet: bill.austin@durham.ac.uk

Work: (44) 191-374-2486

Fax: (44) 191-374-2456

Paleontologist (Nannofossil)

José-Abel Flores

Departamento de Geología

Universidad de Salamanca

Facultad De Ciencias

Salamanca 37008

Spain

Internet: flores@ @rs6000.usal.es

Work: (34) 23-294-497

Fax: (34) 23-294-514

Paleontologist (Nannofossil)

Maria Marino

Dipartimento di Geologia e Geofisica

Università degli Studi di Bari

via E. Orabona, 4

Bari 70125

Italy

Internet: emonopoli@iol.it

Work: (39) 80-544-2554

Fax: (39) 80-544-2625

Paleontologist (Radiolaria)

Kazuhiro Sugiyama

Department of Earth and Planetary Sciences

Nagoya University

Chikusa

Nagoya 464-01

Japan

Internet: k46243a@nucc.cc.nagoya-u.ac.jp

Work: (81) 52-789-3022

Fax: (81) 52-789-3033

Paleontologist (Diatom)

Ulrich Zielinski

Alfred-Wegener-Institut für Polar und Meeresforschung

Columbusstrasse

Bremerhaven 27568

Federal Republic of Germany

Internet: uzielinski@awi-bremerhaven.de

Work: (49) 471-483-1221

Fax: (49) 471-483-1149 
Leg 177

Preliminary Report

Page 4

Paleomagnetist

James E.T. Channell

Department of Geology

University of Florida

1112 Turlington Hall

P. O. Box 117340

Gainesville, FL 32611-7340

U.S.A.

Internet: jetc@nervm.nerdc.ufl.edu

Work: (352) 392-3658

Fax: (352) 392-9294

Paleomagnetist

Dr. Joseph S. Stoner

Department of Geology

University of California

Davis, CA 95616

U.S.A.

Internet: stoner@geology.ucdavis.edu

Work: (530) 752-1861

Fax: (530) 752-0951

Inorganic Geochemist

Christopher D. Charles

Scripps Institution of Oceanography

University of California, San Diego

3119 Sverdup Hall

La Jolla, CA 92093-0220

U.S.A.

Internet: ccharles@ucsd.edu

Work: (619) 534-5911

Fax: (619) 534-0784

Inorganic Geochemist

Stagg L. King

School of Earth and Atmospheric Sciences

Georgia Institute of Technology

221 Bobby Dodd Way

Atlanta, GA 30332-0340

U.S.A.

Internet: king@eas.gatech.edu

Work: (404) 894-3976

Fax: (404) 894-5638

Organic Geochemist

Dr. Minoru Ikehara

Institute of Low Temperature Science

Hokkaido University

Kita-19, Nishi-8, Kita-ku

Sapporo, 060

Japan

Internet: ikehara@soya.lowtem.hokudai.ac.jp

Work: n/a
Physical Properties Specialist

Antony T. Hewitt

Department of Geodesy and Geomatics Engineering

University of New Brunswick

P. O. Box 4400

Fredericton, NB E3B 5A3

Canada

Internet: ahewitt@omg.unb.ca

Work:

Fax: (506) 453-4943

Physical Properties Specialist

Gerhard Kuhn

Alfred-Wegener-Institut für Polar und Meeresforschung

Columbusstrasse

Postfach 120161

Bremerhaven 27515

Federal Republic of Germany

Internet: gkuhn@awi-bremerhaven.de

Work: (49) 471-4831204

Fax: (49) 471-4831149

Sedimentologist

Bernhard Diekmann

Alfred-Wegener-Institut für Polar und Meeresforschung

Columbusstraße 2

P.O. Box 120161

Bremerhaven 27515

Federal Republic of Germany

Internet: bdiekmann@awi-bremerhaven.de

Work: (49) 471-4831-202

Fax: (49) 471-4831-149

Sedimentologist

Gabriel M. Filippelli

Department of Geology

Indiana University/Purdue University, Indianapolis

723 W. Michigan St.

Indianapolis, IN 46202-5132

U.S.A.

Internet: gfilippe@iupui.edu

Work: (317) 274-7484

Fax: (317) 274-7966

Sedimentologist

William R. Howard

Antarctic CRC and Institute of Antarctic and Southern

Ocean Studies

University of Tasmania

GPO Box 252-80

Hobart, Tasmania 7001

Australia

Internet:will.howard@utas.edu.au 
Leg 177

Preliminary Report

Page 5

Work: (61) 3-6226-7859

Fax: (61) 3-6226-2973

Sedimentologist

Sharon L. Kanfoush

Department of Geology

University of Florida

1112 Turlington Hall

Gainesville, FL 32611-7340

U.S.A.

Internet: skanfou@nervm.nerdc.ufl.edu

Work: (352) 392-2231

Fax: (352) 392-9294

Sedimentologist

Alan E.S. Kemp

Department of Oceanography

University of Southampton

Southampton Oceanography Centre

European Way

Southampton SO14 3ZH

United Kingdom

Internet: aesk@soc.soton.ac.uk

Work: (44) 1703-592788

Fax: (44) 1703-593059

Sedimentologist

Suzanne B. O'Connell

Department of Earth and Environmental Sciences

Wesleyan University

265 Church Street

Middletown, CT 06459-0139

U.S.A.

Internet: soconnell@wesleyan.edu

Work: (860) 685-2262

Fax: (860) 685-3651

Sedimentologist

Joseph D. Ortiz

Lamont-Doherty Earth Observatory

Columbia University

Rt. 9W

Palisades, NY 10964-8000

U.S.A.

Internet: jortiz@1deo.columbia.edu

Work: (914) 365-8715

Fax: (914) 365-8155

Sedimentologist

Detlef A. Warnke

Department of Geological Sciences

California State University, Hayward

25800 Carlos Bee Boulevard
Hayward, CA 94542-3088

U.S.A.

Internet: dwarnke@csuhayward.edu

Work: (510) 885-3486

Fax: (510) 885-2526

Norwegian Observer and Sedimentologist

Helga Kleiven

Geologisk Instituit

Universitetet i Bergen

Allégaten 41

Bergen 5007

Norway

Internet: kikki@geol.uib.no

Work: (47) 5558-3535

Fax: (47) 5558-9416

Stratigraphic Correlator, MST Operator

Thomas R. Janecek

Antarctic Research Facility

Florida State University

108 Carraway Building

Tallahassee, FL 32306-3026

U.S.A.

Internet: janecek@gly.fsu.edu

Work: (904) 644-2407

Fax: (904) 644-4214

Stratigraphic Correlator, MST Operator

Katharina Billups

Earth Sciences Department

University of California, Santa Cruz

1156 High Street

Santa Cruz, CA 95064-1077

U.S.A.

Internet: kbillups@earthsci.ucsc.edu

Work: (408) 459-5088

Fax: (408) 459-3074

LDEO Logging Scientist

Ulysses S. Ninnemann

Scripps Institution of Oceanography

University of California, San Diego

Geosciences Research Division

La Jolla, CA 92093-0208

U.S.A.

Internet: uninnema@ucsd.edu

Work: (619) 534-4838

Fax: n/a 
Leg 177

Preliminary Report

Page 6

\begin{abstract}
Sediments in the southeast Atlantic sector of the Southern Ocean were cored during Ocean Drilling Program Leg 177 to study the paleoceanographic history of the Antarctic region on short (millennial) to long (Cenozoic) time scales. Seven sites were drilled along a latitudinal transect across the Antarctic Circumpolar Current (ACC) from $41^{\circ}$ to $53^{\circ} \mathrm{S}$ (Fig. 1; Table 1): three sites at $\sim 41^{\circ} \mathrm{S}$ near the Agulhas Ridge (Sites 1088, 1090, and 1091), two sites at $\sim 47^{\circ} \mathrm{S}$ near the Meteor Rise (Sites 1091 and 1092), and two sites at $50^{\circ}$ and $53^{\circ} \mathrm{S}$ within the circumantarctic siliceous belt (Sites 1093 and 1094). The sites were also arranged along a bathymetric transect ranging from 1976 to $4620 \mathrm{~m}$ water depth, intersecting all of the major deep- and bottom-water masses in the Southern Ocean (Fig. 2).
\end{abstract}

The general goals of Leg 177 were twofold: (1) to document the biostratigraphic, biogeographic, and paleoceanographic history of the Paleogene and early Neogene, a period marked by the establishment of the Antarctic cryosphere and the ACC and (2) to target expanded sections of late Neogene sediments, which can be used to resolve the timing of Southern Hemisphere climatic events on orbital and suborbital time scales, and can be compared with similar records from other ocean basins and with ice cores from Greenland and Antarctica.

More than $4000 \mathrm{~m}$ of sediments were recovered at an average recovery rate of $81 \%$, ranging in age from the middle Eocene to the Holocene. Composite records were constructed at each site from cores in multiple holes by aligning features in the signals of core logging data (magnetic susceptibility, gamma-ray attenuation bulk density, and spectral color reflectance). Leg 177 cores, for which spliced composite sections were constructed, represent the most complete sections obtained from the Southern Ocean.

A continuous 330-m sequence of middle Eocene to lower Miocene sediments, recovered at Site 1090, includes cyclic variations in lithologic parameters and a superb geomagnetic polarity reversal record. The shallow burial depth of this Paleogene section will enable oxygen isotopic measurements of diagenetically unaltered foraminiferal calcite. Site 1090 will likely become a 
deep-sea type section for biomagnetostratigraphic correlations, potential development of an astronomically tuned time scale, and paleoceanographic studies in the Southern Ocean for the middle Eocene through early Miocene. This time period included the buildup of ice on the Antarctic continent, as well as major paleogeographic changes in the Southern Ocean, and marked a shift in Earth's climate from a warm- ("hothouse") to a cold-climate ("icehouse") mode. The study of Site 1090 will help to decipher processes linked to early thermal isolation of Antarctica from warm subtropical gyres, which led to ice-sheet development and attendant changes in sea level. Similar studies can be achieved using late Miocene sequences that recovered at two locations (Sites 1088 and 1092) with lower sedimentation rates.

During Leg 177, we succeeded in recovering complete and expanded sequences at $41^{\circ}$ (Site 1089 ), $47^{\circ}$ (Site 1091), $50^{\circ}$ (Site 1093), and $53^{\circ} \mathrm{S}$ (Site 1094) that accumulated at average rates ranging from 130 to $250 \mathrm{~m} / \mathrm{m}$.y. These sequences are well suited for paleoceanographic studies of the late Pliocene-Pleistocene (i.e., particularly the past 1.5 m.y.) at a temporal resolution of less than 1 k.y. These sites represent the Southern Hemisphere analogs to North Atlantic drift deposits drilled during Legs 162 and 172, and they will be useful for studying the response of the Southern Ocean to orbital forcing and the phase relationships to climate change in the North Atlantic. The location of the cores on a north-south transect between subtropical waters and the Antarctic Zone is optimal for monitoring some key aspects of the climate system including the Antarctic sea-ice field, frontal boundary movements within the ACC, changes in paleoproductivity and opal export rates, and changes in the input of North Atlantic Deep Water to the Southern Ocean.

Shipboard measurements of physical properties (diffuse spectral reflectance, gamma-ray attenuation, density, magnetic susceptibility, and natural gamma radiation) show distinct evidence of cyclicity at Milankovitch time scales, but millennial and perhaps centennial scale changes should be resolvable at some sites. Correlation of millennial-scale climate oscillations detected in marine sediments of the Southern Ocean and the ice-core signals on Greenland and Antarctica offer the opportunity to study the linkages between atmosphere (temperature and $\mathrm{CO}_{2}$ ) and ocean dynamics (sea-surface temperature, productivity, and deep-water circulation) 
Leg 177

Preliminary Report

Page 8

over the past four climatic cycles of the late Pleistocene.

The high-quality sedimentary sequences recovered during Leg 177 fill a critical gap in the distribution of drilled ocean sites and will anchor the southern end of the global array of sites needed to decipher the role of the Southern Ocean in the history of Earth's climatic system.

\section{INTRODUCTION}

The Antarctic ice sheet and the adjacent Southern Ocean act together to form the Antarctic ocean-cryosphere system. Paleoceanographers, climatologists, and geochemists have recognized over the last decade that processes occurring in the Southern Ocean have played a vital role in defining Earth's climate, yet many questions remain about the region's paleoenvironmental evolution (e.g., Kennett and Barron, 1992). The Southern Ocean is an extraordinarily important region for several reasons:

1. The Antarctic cryosphere represents the largest accumulation of ice on Earth's surface and should it melt, sea level would rise by 50 to $60 \mathrm{~m}$. The development and evolution of the Antarctic Ice Sheet and sea-ice field has had a profound influence on global sea-level history, Earth's heat budget, atmospheric circulation, surface- and deep-water circulation, and the evolution of Antarctic biota.

2. The Southern Ocean is one of the primary sites of intermediate-, deep-, and bottom-water formation. For example, almost two-thirds of the ocean floor is bathed by Antarctic Bottom Water $(\mathrm{AABW})$ that mainly originates in the Weddell Sea region. The Southern Ocean represents the "junction box" of deep-water circulation where mixing occurs among water masses from other ocean basins (Fig. 3). As such, the Southern Ocean is perhaps the only region where the relative mixing ratios of deep-water masses can be monitored (e.g., North Atlantic Deep Water [NADW]). As one of the primary sites of deep- and intermediate-water mass formation, the geochemical and climatic fingerprint of Southern Ocean processes is transmitted throughout the world's deep oceans. 
Leg 177

Preliminary Report

Page 9

3. The Antarctic continent is thermally and biogeographically isolated from the subtropics by the Antarctic Circumpolar Current (ACC), a global ring of cold water that contains complex frontal features and upwelling/downwelling cells. The zonal temperature, sea-ice distribution, and nutrient structure within the ACC control biogenic sedimentary provinces that are characteristic of the Southern Ocean. Upwelling of nutrient-rich water results in primary productivity that constitutes nearly one-third of the oceanic total (Berger, 1989). About two thirds of the silica supplied annually to the ocean is removed by siliceous microorganisms in the Southern Ocean. This leads to high accumulation rates of biogenic opal between the Polar Frontal Zone (PFZ) and the northern seasonal limit of sea ice (e.g., DeMaster, 1981; Lisitzin, 1985).

4. Surface waters in the circumantarctic are also important globally because upwelling of deep water and sea-ice formation link the thermal and gas compositions of the ocean's interior with the atmosphere through air-sea exchange. As a result, in most paleogeochemical models atmospheric $\mathrm{CO}_{2}$ is highly sensitive to changes in nutrient utilization and/or alkalinity of Antarctic surface waters (e.g., Sarmiento and Toggweiler, 1984; Siegenthaler and Wenk, 1984; Knox and McElroy, 1984; Broecker and Peng, 1989).

The importance of Antarctica and the Southern Ocean is well known, yet many questions remain regarding the paleoceanographic and paleoclimatic history of this remote region of the world's oceans. The body of quantitative paleoceanographic data from the Southern Ocean is small relative to the climatic importance of the region.

To improve the present latitudinal and bathymetric coverage in the Southern Ocean, seven sites in the high latitudes of the southeast Atlantic Ocean were drilled during Leg 177. Leg 177 represented the return of the JOIDES Resolution to Antarctic waters for the first time in 10 years, since the last major Antarctic drilling campaign in 1987-1988 (Legs 113, 114, 119, and 120). After departing Cape Town on 14 December 1997, a latitudinal transect of sites was drilled beginning at $41^{\circ} \mathrm{S}$ near the southern Subtropical Zone, extending across the Polar Front Zone 
Leg 177

Preliminary Report

Page 10

from $47^{\circ}$ to $50^{\circ} \mathrm{S}$, and ending at $53^{\circ} \mathrm{S}$ in the northern Antarctic region (Fig. 1). The water depth of sites ranged from 1976 to $4624 \mathrm{~m}$, intersecting most of the major deep- and bottom-water masses in the Southern Ocean (Fig. 2). Specific sites were targeted that contain expanded Quaternary, Neogene, and Paleogene sequences that had not been recovered adequately at these depths and latitudes by past drilling. As such, the sediments recovered during Leg 177 fill a critical gap in the distribution of ocean drilled sites and constitute an invaluable archive of cores needed to extend our understanding of Southern Ocean paleoceanography.

\section{PREVIOUS DRILLING IN THE SOUTHERN OCEAN}

Previous deep-sea drilling in the Southern Ocean (Fig. 4), especially cores recovered with the Advanced Hydraulic Piston Corer (APC) and Extended Core Barrel (XCB) systems (Deep Sea Drilling Project [DSDP] Leg 71, Ocean Drilling Program [ODP] Legs 113, 114, 119, and 120), have provided a basic understanding of the paleoceanographic and paleoclimatic evolution of the southern high latitudes during the Cenozoic (see Kennett and Barron, 1992), a period of paleogeographic changes that permitted the development of the Antarctic Circumpolar Current (Kennett, 1977). Sections recovered by previous Antarctic drilling are often incomplete, however, because the APC and XCB systems miss intervals at core breaks even under ideal conditions and apparent $100 \%$ recovery in single holes (Ruddiman et al., 1986). In addition, cores are easily disturbed when recovered in the high seas often encountered in the Southern Ocean. Problems with incomplete core recovery, core disturbance, the presence of hiatuses, and diminished carbonate preservation at the high latitudes of the Southern Hemisphere have hampered efforts to obtain continuous paleoclimatic records, especially those of Neogene age, in the Southern Ocean. One of the primary goals of Leg 177 was to recover complete sections by drilling multiple holes that are used to construct continuous composite sections in real time.

A major deficiency in the distribution of ocean-drilled cores is the lack of late Neogene sequences from the southern high latitudes that would permit the generation of continuous stratigraphic and paleoenvironmental signals. Compared to the superb records now available 
from the high-latitude North Atlantic Ocean (Legs 94, 154, 162, and 172), the Southern Ocean had relatively few sites suitable for high-resolution paleoclimatic studies. Expeditions by ODP to the South Atlantic and Indian sectors of the Southern Ocean during 1987-1988 (Legs 113, 114, 119, and 120) acquired good Paleogene sequences, but relatively few late Neogene records were recovered that would be suitable for studies of Neogene paleoclimatology. Of the 32 sites drilled during these four legs, only one site (ODP Leg 114, Site 704), had sufficient stratigraphic continuity and carbonate content during the Pliocene-Pleistocene to be suitable for highresolution paleoclimatic studies. Thus, the recovery of long, continuous sequences from the Southern Ocean was one of the major goals behind Leg 177.

\section{REGIONAL TECTONIC SETTING}

Many of the sites drilled during Leg 177 are associated with the Agulhas Basin and are arranged along a latitudinal transect extending from the Agulhas Fracture Zone Ridge in the north, to Meteor Rise in the subantarctic, and to Shona Ridge and Bouvet Island in the south (Figs. 1, 5, 6). The Agulhas Basin lies on the African plate and is bounded by the Agulhas Fracture Zone to the north, the Southwest Indian Ridge to the south, the Meteor Rise on the west, and the Agulhas Plateau to the east. The topographic complexity of the Agulhas Basin bears testimony to its tectonic history (du Plessis, 1977; LaBrecque and Hayes, 1979; Cande et al., 1988; LaBrecque, 1986; Raymond and LaBrecque, 1988, 1991; Henson and Ruppel, in press).

The three northern sites (Sites 1088, 1090, and 1091) are associated with the Agulhas Ridge (Fig. 5), which is an elongate topographic feature that parallels the Agulhas Fracture Zone. The Agulhas Ridge extends from the northern tip of the Meteor Rise and terminates abruptly at $40^{\circ} \mathrm{S}$, $15^{\circ} \mathrm{E}$, where it intersects the northern end of an abandoned spreading axis in the Agulhas Basin. At $\sim 65 \mathrm{Ma}$, the spreading axis south of the Agulhas Fracture Zone jumped $825 \mathrm{~km}$ to the west, and motion along the transform fault was abandoned (du Plessis, 1977; LaBrecque and Hayes, 1979; Barker, 1979). Before the ridge jump, the very large offset Agulhas transform (1400 km displacement of the spreading axis or maximum age offset of $\sim 45 \mathrm{Ma}$ ) was subjected to 
Leg 177

Preliminary Report

Page 12

increasing compressional stress as a result of the changing relative motion of the South American and African plates. This compression across the transform may have resulted in thrusting of the South American plate over the African plate, creating the Agulhas Fracture Zone Ridge (C. Raymond, pers. comm., 1996). Alternatively, the Agulhas Ridge may have formed from extension at the fracture zone resulting in serpentinite diapirism (Bonatti, 1978), or volcanic construction resulting from extension and/or a robust magma source, such as the Shona Hotspot (Menard and Atwater, 1969; Kastens, 1987; Hartnady and le Roex, 1985).

Site 1088 is located at the northeastern end of the Agulhas Ridge, near the intersection of the fossil ridge transform (Fig. 5), where it is a broad feature with $2250 \mathrm{~m}$ of relief. Site 1089 is located north of the Agulhas Ridge in the southernmost Cape Basin where the oceanic crust is older than magnetic Anomaly 34 (Upper Cretaceous; Fig. 6). Site 1090 is located on the southwest portion of the Agulhas Ridge, where it narrows considerably and the topography steepens and becomes more intricate.

Sites 1091 and 1092 are associated with the Meteor Rise, which is one of the dominant topographic features in the southeast Atlantic and marks the westward limit of the Agulhas Basin (Fig. 5). This oval-shaped, aseismic plateau rises to water depths of $2000 \mathrm{~m}$ and consists of basement highs with intervening depositional basins. The Meteor Rise is the conjugate feature of the Islas Orcadas Rise in the western South Atlantic, and formed either by (1) effusive volcanism at the developing rift zone associated with the ridge jump from the Agulhas Basin to the west at \%62 Ma (Fig. 7; LaBrecque and Hayes, 1979; Mutter et al. 1988) or (2) passage of the Shona Hotspot across the Agulhas Fracture Zone and the subsequent ridge jump to the preweakened hotspot trace (Hartnady and le Roex, 1985). Site 1091 is located on the western flank of Meteor Rise on magnetic anomalies 24-25 (early Eocene-late Paleocene), which represents the oldest oceanic crust between the Meteor Rise and the Mid-Atlantic Ridge (Fig. 6). Site 1092 is located on the north central Meteor Rise (water depth $1976 \mathrm{~m}$ ) and is probably underlain by volcanic basement of early Eocene age or older. 
Site 1093 is associated with the Shona Ridge that was formed by a hotspot (Shona Hotspot) that may presently reside between $50^{\circ}$ and $52.5^{\circ} \mathrm{S}$ near an anomalously shallow segment of the Mid-Atlantic Ridge (Hartnady and le Roex, 1985; Douglass et al., 1995). Acoustic basement is anomalously smooth in the region of Site 1093, and is estimated to be located on late Miocene crust by extrapolating magnetic anomalies of Cande and Kent (1992). Lastly, the southernmost Site 1094 is located in a small sedimentary basin north of Bouvet Island. This site is located close to the Bouvet Fracture Zone, where the basement age is not well defined from the available magnetic data.

\section{HYDROGRAPHY}

Leg 177 sites are situated along a transect across the ACC (Fig. 1). The ACC consists of a cold, surface-water mass that rings Antarctica and contains complex fronts and upwelling/downwelling cells. In the South Atlantic, the ACC has a strongly banded velocity field and can be divided into three distinct zones separated by frontal boundaries (Peterson and Stramma, 1991). In the north, the ACC is bounded by the Subtropical Front that marks the northward limit of the Subantarctic Zone. Sites 1088, 1090, and 1091 are located in the northern Subantarctic Zone between the Subtropical Front and the Subantarctic Front to the south. Sites 1091 and 1092 are located in the PFZ that is bounded by the Subantarctic Front to the north and the Polar Front to the south. The average width of the PFZ in the South Atlantic off Africa is 670 $\mathrm{km}$, and it is centered at $45^{\circ} \mathrm{S}$ with a span of roughly $\pm 2.5^{\circ}$ latitude (Lutjeharms, 1985). The PFZ separates cold, nutrient-rich Antarctic surface water to the south from warmer, less nutrient-rich Subantarctic Surface Water to the north. The PFZ also represents a transition zone in sediment lithology from diatom ooze near the Polar Front to a mixed siliceous-calcareous ooze near the Subantarctic Front. South of the Polar Front is the Antarctic Zone that is marked by cold, silicarich Antarctic surface water. Site 1093 is located at $\sim 50^{\circ} \mathrm{S}$ in the northern Antarctic Zone close to the present-day Polar Front, and about $5^{\circ}$ north of the average winter sea-ice edge. Site 1094 is located south of the Polar Front in the ice-free Antarctic Zone, close to the average winter sea-ice edge. 
Leg 177

Preliminary Report

Page 14

The water depths of the sites range from 1976 to $4620 \mathrm{~m}$. The bathymetric distribution of sites intersects all major deep- and bottom-water masses in the Southern Ocean, including upper and lower Circumpolar Deep Water (CPDW), NADW, and AABW. Two partial depth transects were drilled on the Agulhas Ridge and Meteor Rise. Sites 1088, 1090, and 1089 form a depth transect at 2083, 3718, and $4620 \mathrm{~m}$, respectively, from the crest of the Agulhas Ridge to the deep Cape Basin. On the Meteor Rise, Sites 1092, 704, and 1091 form a partial depth transect at 1976, 2532, and $4378 \mathrm{~m}$, respectively.

Sites 1088 (2083 m) and $1092(1976 \mathrm{~m})$ are the shallowest sites and are positioned near the interface of upper NADW and upper CPDW. Site 1090 (3718 m) is near the interface of lower NADW and CPDW. The remaining Sites 1089, 1091, 1093, and 1094 are positioned within lower CPDW, and fall along a linear trend marked by decreasing salinity and temperature toward the south, which may reflect decreasing input of NADW (Fig. 8).

\section{DRILLING STRATEGY}

During the past several years, ODP has been drilling in the Atlantic ocean to study past changes in Earth's climate. Leg 177 represents the southernmost anchor of sites needed to complete the Atlantic paleoceanographic transect. The strategy during Leg 177 was to drill a series of sites along a latitudinal transect that encompasses the past dynamic range of the Antarctic sea-ice field and frontal boundary movements within the ACC. Sites were selected along a bathymetric gradient, ranging from 2100 to $4600 \mathrm{~m}$, to study changes in deep-water circulation.

The drilling strategy included seven primary sites to recover expanded late Neogene sections across latitude and depth transects in the Subantarctic and Antarctic regions. We specifically targeted sites with high sedimentation rates on sediment drifts and in the region of the circumantarctic biogenic silica belt (Fig. 9). Four of the sites (Sites 1089, 1091, 1093, and 1094) exhibit average sedimentation rates exceeding 100 m/m.y., offering the opportunity for high- 
resolution paleoclimatic studies. The two southern sites (1093 and 1094) are the first to recover a complete composite section by triple-APC/XCB coring from the circumantarctic silica belt.

\section{SCIENTIFIC OBJECTIVES}

The broad scientific themes of Leg 177 were twofold.

1. Document the biostratigraphic, biogeographic, paleoceanographic, and paleoclimatic history of the Southern Ocean during the Cenozoic, including the evolution and stability of the Antarctic cryosphere, and

2. Construct records during the Quaternary and late Neogene with millennial or high temporal resolution to better understand the role of the Southern Ocean in climate change on orbital and suborbital time scales.

\section{Paleoceanographic and Biogeochemical Objectives}

\section{Evolutionary History and Stability of the Antarctic Cryosphere}

The Paleogene section at Site 1090 is shallowly buried, and thus oxygen isotopic measurements of foraminifers are not likely to have been compromised by diagenetic alteration. The study of oxygen isotopic variation coupled with microfossil distribution and abundance patterns may provide insight into the growth and stability of the Antarctic Ice Sheet and the ACC during the Paleogene.

\section{Development of the ACC and its Associated Frontal Systems}

Thermal isolation of the Antarctic continent was intimately linked to tectonic and paleoceanographic changes that led to the establishment of a zonal circulation system, the ACC (Kennett, 1977). Knowledge of the timing and strength of thermal isolation is important for understanding polar heat transport and its effect on the development and stability of the Antarctic Ice Sheet. The establishment and expansion of the ACC has also influenced intermediate-, deep-, 
Leg 177

Preliminary Report

Page 16

and bottom-water formation in the Southern Ocean. Together with sites previously drilled in the South Atlantic sector of the Southern Ocean (e.g., Sites 689, 690, 703, and 704), Sites 1088, 1090, and 1092 will permit us to study the development of the ACC during the Paleogene and early Neogene (Fig. 4). For the late Neogene, Leg 177 sites form a complete latitudinal transect from $41^{\circ}$ to $53^{\circ} \mathrm{S}$ that permits reconstruction of the paleolatitudinal position of the Polar Front, similar to studies carried out on piston cores from the late Quaternary (Prell et al., 1979; Morley, 1989; Howard and Prell, 1992).

\section{History, Distribution, and Seasonal Variation of Sea Ice}

Sea ice is presently characterized by rapid and large-scale seasonal variations, and it affects gas and heat exchange between ocean and atmosphere, ocean circulation and the formation of water masses by the rejection of salt, atmospheric circulation and wind speeds, surface albedo, and the biological production and distribution of organisms. Changes in sea-ice distribution may have been among the most important controls on Southern Hemisphere climate during the late Pleistocene. Analysis of siliceous microfossils indicative of sea ice in southern sites (Sites 1091 through 1094) will be used to reconstruct the distribution and seasonality of sea ice in the Southern Ocean during the late Pliocene-Pleistocene.

\section{History of Southern Ocean Primary Productivity and its Effect on Atmospheric $p \mathrm{CO}_{2}$}

During glacial periods, opal accumulation rates and export production may have increased substantially within the PFZ and may have been fueled by iron fertilization of surface water delivered by aeolian input from glacial Patagonian deserts (Kumar et al., 1995). Differences exist, however, regarding whether net productivity increased or remained the same in the Southern Ocean during the last glaciation (Kumar et al., 1995; Frank et al., 1996; Francois et al., 1998). Leg 177 sediments will be important for testing various hypotheses related to glacial-tointerglacial changes in productivity and nutrient cycling in the Southern Ocean.

\section{Evolution of the Antarctic Biogenic Silica Belt and its Effect on the Global Marine Silica Budget}

Since $\sim 36 \mathrm{Ma}$, the Southern Ocean has acted as a major sink for biogenic opal, reflecting increased surface-water productivity as a result of polar cooling and upwelling in the 
circumantarctic (Baldauf et al., 1992). Expansion of the biogenic silica belt may have significantly influenced the distribution of nutrients in the ocean. Leg 177 drilled two sites (Sites 1093 and 1094) in the Antarctic biogenic silica belt that represent the first verifiably complete late Pliocene-Pleistocene sequences from this region. Study of these thick sequences of diatom ooze, including laminated diatom mats, will permit estimation of silica accumulation rates, which will be important for assessing the role of these deposits in the dissolved silica budget of the world's oceans.

\section{Changes in the Production and Mixing Ratios of Various Deep-and Bottom-Water Masses}

The Southern Ocean is unique in that its deep water (mainly Circumpolar Deep Water) is a mixture of deep-water masses from all ocean basins (Fig. 3). As such, monitoring changes in the chemistry of Southern Ocean deep water provides an opportunity to reconstruct changes in the mean composition of the deep ocean. The Southern Ocean is perhaps the only region where fluctuations in the production rate of NADW can be monitored unambiguously (Oppo and Fairbanks, 1987; Charles and Fairbanks, 1992). The South Atlantic sector of the Southern Ocean represents the initial point of entry of NADW into the Circumpolar Current and, therefore, is highly sensitive to changes in the strength of the NADW conveyor. The bathymetric distribution of Leg 177 sites is ideal for reconstructing the long-term evolution of the dominant subsurface water masses in the Southern Ocean, and assessing their role in global climate change (Fig. 2).

\section{Timing and Response of Southern Ocean Surface and Deep Waters to Orbital Forcing}

Relatively little is known about the interhemispheric phase response (lead, lag, or in-phase) between the high-latitude Northern and Southern Hemispheres. Imbrie et al. $(1989,1992)$ suggested an early response of surface and deep waters in the Southern Ocean relative to other regional climate responses. This lead has also been observed by other studies (Howard and Prell, 1992; Labeyrie et al., 1986; Charles et al., 1996; Bender et al., 1994; Sowers and Bender, 1995), implying that the Antarctic region played a key role in the driving mechanism of glacial-tointerglacial climate change during the last climatic cycle. It is not known, however, if this early response of the Southern Ocean was characteristic of the entire middle to late Pleistocene the interval dominated by 100-k.y. cyclicity or whether this phase relationship also extends back into 
Leg 177

Preliminary Report

Page 18

the early Pleistocene and Pliocene interval dominated by 41-k.y. cyclicity. Leg 177 sediments (especially Sites 1089, 1091, 1093, and 1094) will provide the material needed to study the response of the Southern Ocean to orbital forcing and its phase relationships with climatic changes in other regions.

Suborbital Climate Change by Comparison with Ice Cores and Other Marine Sediment Records

Highly expanded sections were recovered at four sites (Sites 1089, 1091, 1093, and 1094), which permit the study of climatic variations in the Southern Ocean at suborbital (millennial) time scales. These sedimentary sequences represent the Southern Hemisphere analogs to the North Atlantic drift deposits recovered during ODP Legs 162 and 172. These cores will allow us to determine whether abrupt climate changes, similar to those documented in Greenland ice cores (Dansgaard et al., 1993) and marine records from the high-latitude North Atlantic (Bond et al., 1993; Bond and Lotti, 1995), have occurred in the southern high latitudes. Expanded sections along a latitudinal transect from $41^{\circ}$ to $53^{\circ} \mathrm{S}$ will also permit study of the structure of glacial and interglacial cycles in the Southern Ocean, including the trajectories of deglacial meltwater from the Antarctic continent (Labeyrie et al., 1986). Lastly, correlation between Leg 177 sediment cores and ice cores from Greenland and Antarctica, which now span the last 400 k.y. at Vostok (Antarctica; Petit et al., 1997), will reveal the phase relationships between various variables in the atmosphere and ocean systems, and may contribute to identifying the mechanisms responsible for rapid climate change.

\section{Southern High-Latitude Calcareous and Siliceous Biozonations}

ODP Legs 113, 114, 119, and 120 provided an enormous improvement in southern highlatitude stratigraphy, but further refinement of these biozonations is desirable. Sediments drilled during Leg 177 provide the opportunity to improve dating of Neogene and Paleogene biostratigraphic markers by correlation with orbitally tuned paleoenvironmental signals. In addition, Leg 177 sequences permit study of evolutionary processes (patterns, modes, and timing of speciation and diversification), the development of Southern Hemisphere bioprovinces (e.g., endemism), and the response of the biota to long- and short-term environmental changes. 
Early Low-Temperature Chert Diagenesis in Sediment from the Antarctic Biogenic Silica Belt Although chert is ubiquitous in the geological past (e.g., Eocene cherts), few examples of recent porcellanites exist in the geologic record except those found in diatomaceous deposits of the Southern Ocean (Bohrmann et al., 1990, 1994). Very early transformation of silica from opal-A to opal-CT (strongly cemented porcellanites) has been observed at shallow burial depth in a low-temperature environment in cores recovered near Site 1094 (Bohrmann et al., 1990, 1994). By sampling pore fluids and solid phases at Site 1094, it will be possible to study the nature and rates of silica diagenetic reactions in these young sediments. In addition, measurements of physical properties and heat flow at Site 1094 will better characterize the conditions under which these young porcellanites formed.

\section{Geomagnetic Paleointensity}

U-channel sampling of Leg 177 cores will be used to construct continuous records of variations in the intensity of Earth's magnetic field. Comparison of these signals from the high-latitude Southern Hemisphere with similar results obtained from the North Atlantic will test whether these observed variations reflect changes in the intensity of Earth's dipole field. If so, then these dipolar paleointensity changes will provide a powerful stratigraphic tool that can be used to correlate cores globally. In addition, the high sedimentation rates of Leg 177 sites offer the opportunity to study transitional field behavior at polarity reversal boundaries and, perhaps, brief excursions and secular variation of the magnetic field in the high-latitude Southern Hemisphere.

\section{PRINCIPAL RESULTS}

\section{SITE 1088}

Site 1088 is located on the Agulhas Ridge in the southeast Atlantic Ocean at a water depth of $2083 \mathrm{~m}$. This bathymetric setting places the site near the interface between NADW and CPDW. The primary objective of Site 1088 was to recover a long Cenozoic carbonate sequence that could be used to study paleoceanographic change near the Subtropical Front, which today is 
Leg 177

Preliminary Report

Page 20

located north of the Agulhas Ridge.

Three holes were drilled representing a combined 223.4-m section, consisting predominantly of carbonate microfossils representing sediment deposition from the Holocene to middle Miocene ( 13-14 Ma). The sediments recovered are predominantly nannofossil ooze, foraminifer-bearing nannofossil ooze, foraminiferal nannofossil ooze, and nannofossil foraminiferal ooze. Carbonate percentages vary from 85 to $95 \mathrm{wt} \%$ and the abundance of foraminifers decreases progressively downhole.

Sedimentation rates averaged $10 \mathrm{~m} / \mathrm{m} . \mathrm{y}$. in the Pleistocene, $7 \mathrm{~m} / \mathrm{m} . \mathrm{y}$. in the Pliocene, 17-30 $\mathrm{m} / \mathrm{m} . \mathrm{y}$. in the late Miocene, and $11 \mathrm{~m} / \mathrm{m}$.y. during the middle Miocene. Only two short depth intervals (0-5.5 and 122-129 m composite depth [mcd]) were cored in more than one hole and, as a result, continuity of the sedimentary section could not be documented and a continuous spliced record could not be constructed at Site 1088. Magnetic inclinations were low and less than expected for the site location $\left(60^{\circ}\right)$ and declinations were highly scattered, suggesting drillstring remagnetization of the core.

High-resolution samples (one per section) of interstitial waters were taken in Hole 1088B, 1.5-115.9 meters below seafloor (mbsf), for major ion and stable isotopic analysis. Many of the results from these samples must await shore-based analyses, but shipboard analyses show that, as expected, chlorinity increases downhole, with a slight local maximum at about 40 mbsf that probably resulted from diffusion of higher salinity water associated with the last glaciation.

Variations in diffuse spectral reflectance suggest the presence of marine isotope stages (MISs) 1 to 13 in Core $177-1088 \mathrm{~B}-1 \mathrm{H}$ in the top $5.5 \mathrm{mbsf}$. Although the upper Pleistocene sequence is marked by relatively low sedimentation rates $(\sim 10 \mathrm{~m} / \mathrm{m} . \mathrm{y}$.$) , the record is similar to that from$ ODP Site 704 to the south $\left(47^{\circ} \mathrm{S}, 7.5^{\circ} \mathrm{E}, 2532 \mathrm{~m}\right)$, and comparison of the two holes will be useful for studying glacial-to-interglacial changes in NADW flux to the Southern Ocean. Sediments recovered at Site 1088 will be useful for studying paleoceanographic change during the Neogene at a temporal resolution of 104 to 105 years. The 140-m section of upper Miocene sediments 
recovered in Holes 1088B and $1088 \mathrm{C}$ is particularly promising in that variations in magnetic susceptibility show evidence of cyclicity in the Milankovitch frequency band. Although a complete composite section was not retrieved, the sediments should provide a detailed record of late Miocene changes in surface- and deep-water circulation.

\section{SITE 1089}

Site 1089 is located in the southernmost Cape Basin in the southeast Atlantic Ocean, just north of the Agulhas Ridge. High rates of sedimentation $(8-13 \mathrm{~cm} / \mathrm{k} . \mathrm{y}$.$) result in an expanded$ sedimentary sequence that is ideally suited for studying environmental changes in response to climate variability on orbital and suborbital time scales. Given these high sedimentation rates, Site 1089 is the Southern Hemisphere analog to the North Atlantic drift deposits drilled during Legs 162 and 172, and it will be useful for determining the response of the Southern Ocean to orbital forcing and the phase relationships to climate change in the North Atlantic. The high accumulation rates at Site 1089 will also permit detailed correlation between marine sediment analyses and ice-core records, especially the Vostok ice-core signal that has now been extended to $420 \mathrm{ka}$ (Petit et al., 1997).

A 264.9-m-thick sedimentary section spanning the interval from the Holocene to late Pliocene $(\sim 2.4 \mathrm{Ma})$ was recovered at Site 1089 . The sediments are predominantly composed of diatoms, nannofossils, and terrigenous mud in varying proportions. Calcium carbonate $\left(\mathrm{CaCO}_{3}\right)$ contents in Hole 1089A average $27.0 \mathrm{wt} \%$ and range from 0.6 to $69.3 \mathrm{wt} \%$, whereas total organic carbon (TOC) varies between 0 and $0.82 \mathrm{wt} \%$ with an average value of $0.43 \mathrm{wt} \%$. Although Site 1089 is deep (4624 m), benthic foraminifer abundance is fairly constant downhole to about $220 \mathrm{mbsf}$, below which it goes to zero. It should be possible, therefore, to produce a continuous stable isotope stratigraphy in the upper $220 \mathrm{mbsf}$. No major lithologic boundaries occur within Site 1089 , and only one lithologic unit was identified.

The upper $100 \mathrm{~m}$ of the section, representing approximately the Brunhes Chron (0.78 Ma to 
Leg 177

Preliminary Report

Page 22

present), is nearly complete. Variations in spectral color reflectance, $\mathrm{CaCO}_{3}$, bulk density, and magnetic susceptibility permit the prediction of glacial and interglacial Stages 1 to 19, constrained by diatom and calcareous nannofossil biostratigraphy. With four holes drilled to more than 118 mbsf at Site 1089, a continuous spliced record was constructed to a depth of 94 mcd by aligning features in the records of closely spaced physical properties measurements. Core logging data obtained at 2- to 6-cm sampling intervals show cyclic variations at Milankovitch frequencies as well as variations at higher (sub-Milankovitch) frequencies. Postcruise analysis of these signals will be useful for delineating climatic variability on these time scales. Preservation of remanent magnetization is good in the upper $100 \mathrm{~m}$ and preliminary results are encouraging for constructing the first detailed Southern Hemisphere record of geomagnetic paleointensity during the Brunhes Chron.

A series of 3- to 15-m-thick deformed sediment units, possibly slump or slide deposits, were cored between 95 and 156 mcd. Soft-sediment deformation is manifested in the sediment by dipping and/or contorted beds, sharp color contacts, and microfaults. The Brunhes/Matuyama boundary occurs in the interval from 105 to 114 mbsf in Hole 1089B; however, the transition is not well preserved because of soft-sediment deformation that affects the interval from the lowest Brunhes Chron to the top of the Jaramillo Subchron. However, even within the deformed sediment interval, laminations and burrow structures are preserved and suggest that the stratigraphic section is relatively intact. Postcruise analysis may allow us to piece together a composite section that eliminates several of the deformed intervals.

Polarity transitions in cores from Hole 1089B define the lower boundary of the Jaramillo Subchron at 151.6 to $153.6 \mathrm{mbsf}$, and the upper and lower boundaries of the Olduvai Subchron at 213.8 to $215.8 \mathrm{mbsf}$ and 225.5 to $227.6 \mathrm{mbsf}$, respectively. We place the Pliocene/Pleistocene boundary at $\sim 229$ mcd at Site 1089 .

Biomagnetostratigraphy provides an age-depth relationship that indicates continuous sedimentation at Site 1089 since the late Pliocene ( 2.4 Ma). Sedimentation rates average $\sim 128$ m/m.y. in the upper $94 \mathrm{mcd}(\sim 0.7 \mathrm{Ma}), \sim 180 \mathrm{~m} / \mathrm{m}$.y. between 94 and $156 \mathrm{mcd}(\sim 0.65$ to $1 \mathrm{Ma})$, 
$\sim 110 \mathrm{~m} / \mathrm{m}$.y. from 156 to $230 \mathrm{mcd}(1-1.8 \mathrm{Ma}$ ), and $\sim 84 \mathrm{~m} / \mathrm{m} . \mathrm{y}$. from 230 to $280.6 \mathrm{mcd}$ (1.7-2.4 Ma). The middle interval of relatively high sedimentation rates (between 95 and $154 \mathrm{mcd}$ ) corresponds to the disturbed section, but the superposition of biostratigraphic datums is as expected in this interval. Within the last 400 k.y. (upper $60 \mathrm{mbsf}$ ), sedimentation rates were higher during interglacial than during glacial intervals, probably because of enhanced carbonate production and/or preservation during interglacials (Howard and Prell, 1994).

Pore-water profiles from Site 1089 indicate reducing conditions such that sulfate reduction is complete by $50 \mathrm{mbsf}$ and methane concentrations are high below this depth in the hole. The $\mathrm{Ca} 2+$ profile shows a dramatic decrease in the sulfate reduction zone reaching a minimum at 50 mbsf. This $\mathrm{Ca} 2+$ decrease results in unusually high $\mathrm{Mg} / \mathrm{Ca}$ ratios because $\mathrm{Mg} 2+$ concentrations remain at near-seawater values.

\section{SITE 1090}

Site 1090 is located in the central part of the Subantarctic Zone on the southern flank of the Agulhas Ridge. The water depth (3699 m) places it near the boundary between NADW and underlying lower CPDW, and above the calcium-carbonate compensation depth (CCD). Together with Sites $1088(2083 \mathrm{~m})$ and 1089 (4624 m) it forms a depth transect that intersects most of the major water masses of the South Atlantic.

Five holes were drilled to $397.5 \mathrm{mbsf}$, spanning the Holocene to middle Eocene ( 46 Ma), and including a 14-m.y. hiatus at $\sim 70$ mcd that spans much of the lower Pliocene to lower Miocene record. From Hole 1090A we obtained one core that overpenetrated the mudline and recovered 7 $\mathrm{m}$ of sediment. The deepest hole (1090B) penetrated to a depth of $397.5 \mathrm{mbsf}$ with APC coring to Core 177-1090B-20H (184.7 mbsf) and XCB coring thereafter. Hole 1090C was drilled to a depth of $69.3 \mathrm{mbsf}$ (Core 177-1090C-8H) to recover a continuous Pleistocene-Pliocene section and the interval containing the lower Pliocene-lower Miocene hiatus. Holes 1090D and 1090E were drilled to APC refusal depths of 225.9 and 236.7 mbsf, respectively. The strategy for Holes 
Leg 177

Preliminary Report

Page 24

1090B, 1090D, and 1090E was to recover the lower Miocene-Oligocene record in its entirety by APC coring. We constructed a continuous spliced record to $212 \mathrm{mcd}$ (and perhaps $245 \mathrm{mcd}$ ), corresponding to the early Oligocene.

Quaternary sediments, consisting of alternating foraminiferal nannofossil ooze, diatom-bearing nannofossil ooze, and mud-bearing nannofossil ooze, extend to $44 \mathrm{mcd}$ at sedimentation rates averaging $33 \mathrm{~m} / \mathrm{m}$.y. In Hole 1090C, the Brunhes/Matuyama boundary (0.78 Ma) lies between 18.0 and 19.2 mbsf. The top (0.99 Ma) and base (1.07 Ma) of the Jaramillo Subchron lie in the 24.6-25.4 and 27.7-28.4 mbsf intervals, respectively, in Hole 1090C. Two hiatuses may occur between 0.42 and $0.64 \mathrm{Ma}$ and from 1.3 to $1.8 \mathrm{Ma}$; shore-based analysis is needed for confirmation. Variations in color reflectance permit the identification of glacial and interglacial Stages 1 to 12 in the upper $18 \mathrm{mcd}$, supported by identification of biostratigraphic events. Isotope Stage 11 is particularly prominent because of its exceptionally white color and high nannofossil carbonate content. Cyclic variations in the color reflectance and gamma-ray attenuation (GRA) bulk density signals may reflect the shift from the 41-k.y. world to the 100k.y. world at about 30 mcd.

The upper Pliocene sequence was deposited at sedimentation rates of 11 to $13 \mathrm{~m} / \mathrm{m}$.y. In Hole 1090C, the top (1.77 Ma) and base (1.99 Ma) of the Olduvai Subchron were recognized in the 35.3-36.0 and 37.6-38.2 mbsf intervals, respectively. Diatom biostratigraphy indicates a hiatus at $\sim 55 \mathrm{mcd}$ that spans the Gauss/Matuyama boundary from 2.5 to $2.6 \mathrm{Ma}$.

A hiatus was encountered at $\sim 70 \mathrm{mcd}$, marked by a lithologic change from white nannofossil ooze to reddish muddy nannofossil ooze and a tephra layer composed of vitric ash with greenish brown volcanic glass shards. Sediments above the hiatus are early Pliocene in age and contain manganese nodules. Below the hiatus, approximately $330 \mathrm{~m}$ of sediment was recovered consisting of mud-bearing diatom ooze and mud- and diatom-bearing nannofossil ooze and chalk ranging in age from early Miocene to middle Eocene. Sedimentation rates average $10 \mathrm{~m} / \mathrm{m} . \mathrm{y}$. in the early Miocene to middle Eocene, and increase to $30 \mathrm{~m} / \mathrm{m}$.y. in the upper Eocene opal-rich sediments that include intervals of well-laminated diatom ooze. Middle Eocene carbonate-rich 
sediments have lower sedimentation rates $(\sim 10 \mathrm{~m} / \mathrm{m} . \mathrm{y}$.$) .$

The potential for paleomagnetic reversal stratigraphy below the hiatus is superb, even in the cores that were recovered by XCB. Site 1090 holds much promise for detailed correlations of biostratigraphic datums to the geomagnetic polarity time scale during the early Miocene to middle Eocene.

Pore waters of Site 1090 can be characterized as suboxic, with sulfate reduction occurring at very low rates. Pore-water profiles indicate a sharp break at 290 mbsf, corresponding to an impermeable layer (presumably a chert recovered as fragments in the top of Core 177-1090B$32 \mathrm{X}$ ) that posed a barrier to diffusion in interstitial waters. Pore-water regimes above and below the diffusion barrier evolved independently because of the isolation imposed by the impermeable chert.

In summary, the importance of Site 1090 is twofold: (1) the Pleistocene to upper Pliocene section above the hiatus will be useful for reconstruction of high-latitude Southern Hemisphere paleoclimate at moderate resolution (30 m/m.y.) and (2) the middle Eocene-lower Miocene section below the hiatus will potentially be an important section for biomagnetostratigraphic correlations, astronomical tuning, and paleoceanographic studies of the late Paleogene and early Miocene. Cyclic variations in lithology may permit the development of an astronomically tuned time scale for the late Paleogene-early Neogene, similar to that developed during Leg 154 (Weedon et al., 1997). The shallow burial of the section at Site 1090 offers an opportunity to produce a stable isotope stratigraphy that has not been compromised by diagenetic alteration. The Paleogene interval is especially significant because it spans the time period associated with the onset of Antarctic glaciations, early production of cold surface and bottom waters, and paleogeographic changes (e.g., the separation of Australia and Antarctica and opening of the Drake Passage) which led to the establishment of the ACC. 
Leg 177

Preliminary Report

Page 26

\section{SITE 1091}

Site 1091 is located in the PFZ on the western flank of the Meteor Rise, approximately $3^{\circ}$ north of the present-day Polar Front. The water depth of $4378 \mathrm{~m}$ places the site within lower CPDW. The primary objective at Site 1091 was to recover a high-resolution Pliocene-Pleistocene sequence within the PFZ that could be used to study (1) the history of migration of the Polar Front and Antarctic sea-ice field; (2) glacial-to-interglacial changes in productivity (export production); (3) millennial-scale climate oscillations in the Southern Ocean and their relation to North Atlantic and polar ice cores; (4) the melting history of the Antarctic ice sheet and associated meltwater plumes during glacial-to-interglacial cycles of the late Pleistocene; and (5) changes in lower CPDW properties and their responses to changes in the flux of NADW to the Southern Ocean.

Five holes were drilled at Site 1091 to obtain a complete section deposited under high sedimentation rates. Hole 1091A was the deepest hole cored with the APC to a depth of 310.9 mbsf with a recovery rate of $90 \%$. Basal sediments are early Pliocene ( 3.4 Ma) in age. The remaining four holes provided overlap to fill coring gaps in Hole 1091A and resulted in a continuous spliced section to $234 \mathrm{mcd}$ ( 1.7 Ma). One lithologic unit was defined consisting of diatom-rich ooze, with minor and varying amounts of nannofossils, foraminifers, and mud. Calcium carbonate contents in Hole 1091A are relatively low, ranging from 0.2 to $58.9 \mathrm{wt} \%$ with an average value of $5.7 \mathrm{wt} \%$. Despite the low carbonate content, planktonic and benthic foraminifers are sufficiently abundant in most samples for stable isotopic analysis. Total organic carbon contents vary between 0.17 and $0.91 \mathrm{wt} \%$ with an average value of $0.60 \mathrm{wt} \%$.

Because of the close proximity of Site 1091 to the Polar Front, the underlying sediments should document past movements of this front. Extensive laminated Thalassiothrix diatom mat deposits, analogous to those of the eastern equatorial Pacific (Kemp and Baldauf, 1993), occur at several horizons. Sedimentation rates are high, averaging $140 \mathrm{~m} / \mathrm{m} . \mathrm{y}$. in the Pleistocene section. Carbonate-rich, interglacial periods are easily recognized by their brightness in the signal of diffuse color reflectance. For example, peaks in red reflectance (650-700 nm) at 26.5, 38, and 49 
mcd correlate to interglacial Stages 7, 9, and 11, respectively, which is supported by biostratigraphic information. Downhole variations of physical properties (diffuse spectral reflectance, GRA density, and magnetic susceptibility) show distinct evidence of cyclicity at Milankovitch and suborbital time scales.

A transition in sedimentation occurred at $\sim 2.0$ Ma that is marked by a change from rapidly accumulated diatomaceous sediments above to lower opal contents and lower sedimentation rates below. This event represents an important change in opal export production in the Southern Ocean during the latest Pliocene and was recognized previously in ODP Hole 704 (Froelich et al., 1991a; Hodell and Venz, 1992), which is located only $\sim 60 \mathrm{~km}$ to the east of Site 1091 on the crest of Meteor Rise.

Natural remanent magnetization (NRM) at Site 1091 was affected by a drill-string overprint that was largely removed at peak demagnetization fields in excess of $10 \mathrm{mT}$; however, the resulting inclination values are highly scattered especially during the Matuyama Chron. The Brunhes/Matuyama boundary can be identified in the 95.5-102.4 mbsf interval in Hole 1091A. The Matuyama/Gauss boundary is tentatively identified between 285.8 and $288.7 \mathrm{mbsf}$ in Hole 1091A.

The redox conditions in Site 1091 sediments can be classified as reducing on the basis of dissolved H2S (by smell), but sulfate concentrations decrease only modestly from near-bottomwater concentrations of about $28 \mathrm{mM}$ at $4 \mathrm{mbsf}$ to about $22 \mathrm{mM}$ around $300 \mathrm{mbsf}$.

In summary, Site 1091 represents the midpoint (at $47^{\circ} \mathrm{S}$ ) of a Pliocene-Pleistocene latitudinal transect across the ACC. The high sedimentation rates during the Pleistocene at Site 1091 (145 m/m.y.) complement the records obtained at Sites 1089 (128 m/m.y.), 1093 (250 m/m.y.), and $1094(140 \mathrm{~m} / \mathrm{m} . \mathrm{y}$.$) at 41^{\circ}, 50^{\circ}$, and $53^{\circ} \mathrm{S}$, respectively. This latitudinal transect of sites with high sedimentation rates will be used to reconstruct past movement of the ACC and Antarctic sea-ice field frontal boundaries during the Pliocene-Pleistocene, and to study the impact of climate variability on processes in the Southern Ocean on orbital and suborbital (millennial) time scales. 
Leg 177

Preliminary Report

Page 28

\section{SITE 1092}

Site 1092 is located on the northern Meteor Rise in the PFZ, $\sim 3^{\circ}$ north of the present-day position of the Polar Front. The water depth $(1976 \mathrm{~m})$ places the site above the regional carbonate lysocline and CCD and within a mixing zone between upper NADW and CPDW. The impetus for drilling Site 1092 came from the record obtained at ODP Site 704, located only 34 nmi southeast of Site 1092. The goal of Site 1092 was to improve upon Site 704 by recovering a continuous upper Miocene to Pleistocene section.

Three holes were drilled by the APC to depths of $188.5 \mathrm{mbsf}$ (Hole 1092A), $168.9 \mathrm{mbsf}$ (Hole 1092B), and 165.5 mbsf (Hole 1092C) with high recovery in all holes (97\%, 86\%, and 91\%, respectively). A continuous spliced section was constructed to $188.5 \mathrm{mcd}$. The sediments consist of pale brown-green to pure white nannofossil ooze with varying mixtures of diatomaceous and foraminiferal ooze and mud. One lithologic unit was defined and divided into two subunits at 54 mcd on the basis of a change from alternating calcareous and diatomaceous ooze above to dominantly nannofossil ooze below. Calcium carbonate is present throughout the sediment column, varying from 16.7 to $94.6 \mathrm{wt} \%$ with an average value of $80.2 \mathrm{wt} \%$. Total organic carbon contents vary between 0 and $0.70 \mathrm{wt} \%$ with an average value of $0.16 \mathrm{wt} \%$.

The section at Site 1092 ranges in age from the Pleistocene to the early Miocene. Sedimentation rates varied from 10 to $29 \mathrm{~m} / \mathrm{m}$.y. during the Pliocene-Pleistocene and between 4 and $38 \mathrm{~m} / \mathrm{m}$.y. during the Miocene. The pattern of sedimentation-rate change at Site 1092 is similar to Site 704, except that Site 1092 rates are considerably lower. For example, the Pleistocene section at Site 1092 appears to be compressed by half relative to Site 704 . The pattern is also similar to that at Site 1088, including the hiatus in the middle Miocene, except that the lower Pleistocene section is more expanded at Site 1092. Winnowing in the upper and midPleistocene sediment is indicated by well-sorted foraminiferal sands and sedimentation rates averaging $10 \mathrm{~m} / \mathrm{m} . \mathrm{y}$. Several hiatuses punctuate the sediment record at Site 1092: (1) a lower Pliocene hiatus at 65 mcd spans the interval from $\sim 3.8$ to $4.6 \mathrm{Ma}$; (2) one or more hiatuses occur across the Miocene/Pliocene boundary that was tentatively placed between 70 and 75 mcd; and 
(3) a hiatus at 178 mcd spans the earliest late Miocene to the middle middle Miocene from 11 to $13 \mathrm{Ma}$.

The paleomagnetic inclination records are highly discontinuous in the upper $60 \mathrm{mbsf}$ because of drilling disturbance in poorly consolidated nannofossil ooze. Below $70 \mathrm{mbsf}$, the polarity reversal stratigraphy is well resolved where a particularly good upper Miocene sequence is indicated. Correlation of the polarity sequence at Site 1092 awaits detailed shore-based biostratigraphy.

The redox characteristics of Site 1092 can be characterized as generally oxic or suboxic throughout the section. The major cations ( $\mathrm{Ca}, \mathrm{Mg}$, and $\mathrm{Sr}$ ) in interstitial waters vary similarly to those from Sites 1088, 1090, and 704 (Froelich et al., 1991b).

Measurements of physical properties show evidence of distinct cyclicity throughout the record. In the upper $35 \mathrm{mcd}$, large-amplitude variations in color reflectance mirror alternations between siliceous and carbonate sediments during the Pleistocene, whereas the signal is dampened below in sediments dominated by nannofossil ooze. Lithologic cyclicity in the upper Miocene section of Site 1092 may offer the opportunity to test the new late Miocene time scale derived by Shackleton and Crowhurst (1997) at Site 926 (Leg 154).

\section{SITE 1093}

Site 1093 (proposed site TSO-6A) is located north of Shona Ridge, near the present Polar Front and north of the average winter sea-ice edge. The siteis characterized by moderately laminated pelagic sediments deposited at high sedimentation rates $(25 \mathrm{~cm} / \mathrm{k} . \mathrm{y}$.) throughout the Pleistocene within the circumantarctic biogenic silica belt (Fig. 9). The high burial rates of biosiliceous sediment offer an excellent opportunity for the study of millennial- and submillennial-scale climate variability. Site 1093 represents the first time that cores have been recovered from the Antarctic silica belt in multiple APC holes, permitting construction of a complete composite 
Leg 177

Preliminary Report

Page 30

section. At $3624 \mathrm{~m}$, the site is located within lower CPDW.

Six holes were drilled at Site 1093 with a maximum penetration of $597.7 \mathrm{mbsf}$. A continuous spliced section was constructed to a depth of $252 \mathrm{mcd}$, representing the early Pleistocene $(\sim 1.0$ Ma) to Holocene. For Holes 1093A and 1093B, the Brunhes/Matuyama boundary (0.78 Ma) was found in the interval between 205 and $210 \mathrm{mcd}$, yielding an average sedimentation rate of 250 m/m.y. Shipboard multisensor track (MST) results (natural gamma radiation [NGR], GRA bulk density, and magnetic susceptibility) and diffuse color reflectance document lithologic variations on orbital and suborbital time scales, which can be used to interpret climatic changes during the past 1.0 m.y. Preliminary age models based on shipboard MST results indicate that in some interglacial intervals sedimentation rates reached as high as 300 to $700 \mathrm{~m} / \mathrm{m}$.y., permitting a temporal sampling resolution of $100 \mathrm{yr}$ or less. The remarkably expanded and relatively complete section is well suited for paleoceanographic studies on millennial-to-centennial time scales over the last 1 m.y.

The lithology at Site 1093 consists almost exclusively of diatom ooze, including distinctive intervals of laminated diatom mats up to several meters thick. Calcium carbonate contents at Site 1093 were generally low ( $<15 \mathrm{wt} \%$ ) with occasional peaks of up to $56.9 \mathrm{wt} \%$. Despite the low carbonate content, it appears from core-catcher samples that a nearly continuous planktonic foraminiferal isotope stratigraphy (Neoglobiquadrina pachyderma sinistral) and a more-or-less continuous benthic isotope record should be possible over the last $1 \mathrm{~m} . \mathrm{y}$.

Relatively carbonate-rich, interglacial intervals are recognized by their brightness in the signal of diffuse color reflectance. On this basis, we were able to predict MISs 1 through 11 ( 400 k.y.). MIS 11, at 124 mcd, stands out as the "brightest," most carbonate-rich interglacial of the Pleistocene (Howard and Prell, 1994). The transition from glacial MIS 12 to interglacial MIS 11 (Termination V) occurs over an 8-m interval (from 133 to $125 \mathrm{mcd}$ ) and is marked by a thick laminated interval of Thalassiothrix diatom mats. This section provides an unprecedented opportunity to study changes in sedimentation controlled by abrupt climate changes associated with Termination V. 
The recovery of the deeper section below $\sim 255 \mathrm{mcd}$, averaging only $26 \%$, was disappointing in Hole 1093D. This is thought to be the result of thick intervals of laminated diatom mats that were difficult to recover using the APC and particularly the XCB coring systems. Apparently, a brief hiatus (spanning 0.2 m.y.) marks the Pliocene/Pleistocene boundary, and sedimentation rates decrease to $57 \mathrm{~m} / \mathrm{m}$.y. below this level. A hiatus spanning $\sim 2.5 \mathrm{~m}$.y. also marks the latest early Pliocene to latest late Miocene. The oldest sediment recovered at $595 \mathrm{mcd}$ was latest Miocene (6.3-6.9 Ma) in age and contained a Neobrunia mirabilis diatom ooze with similar composition to that recovered at ODP Site 701.

Closely spaced (one per section) interstitial water samples were taken from cores from Hole 1093A between 0 and $63 \mathrm{mbsf}$ for major ion and stable isotopic analysis. One to three samples per core were taken at Holes 1093A and 1093D to a maximum depth of 498 mbsf. Shipboard analyses show that, as normally expected, chlorinity increases downhole, with a well-defined maximum in the interval from 50 to $60 \mathrm{mbsf}$, probably resulting from diffusion of higher salinity water associated with the last glaciation. The chloride profile is identical (within analytical uncertainty) to its lower resolution counterpart in Site 1091. Both sites are characterized by high sedimentation rates, and the presence of diatom mats may be responsible for creating such a distinct chloride maximum. Additional shore-based isotopic analyses and modeling of porewater profiles may permit the estimation of the oxygen isotopic composition and salinity of bottom waters at Site 1093 during the last Ice Age.

Hole 1093D was wireline-logged between 70 and 560 mbsf using the Triple Combination tool and the Geological High-sensitivity Magnetic Tool (GHMT). Good quality resistivity, NGR, and magnetic susceptibility data were obtained that should permit core-log integration using the MST core-logging data. The magnetic susceptibility record obtained from the Pliocene section of Site 1093 shows close similarities to the Pliocene record obtained at lower sedimentation rates at Site 1092.

In summary, the purpose of Site 1093 was to obtain an expanded record of biosiliceous 
Leg 177

Preliminary Report

Page 32

sediments south of the present-day position of the Polar Front to study interactions between rapid climate change on suborbital time scales and the Antarctic surface waters and sea-ice field. We succeeded in obtaining Pleistocene sediments that were deposited at the highest sedimentation rates yet recovered in any pelagic deep-sea section, affording the opportunity to study paleoceanographic processes in response to climate variability on millennial and even centennial time scales. In particular, the high accumulation rates and associated temporal resolution of the sedimentary record will permit detailed correlation of the paleoceanographic history at Site 1093 with results from the Greenland and Antarctic ice cores, especially the Vostok ice core that has now been extended to a depth representing the last 420 k.y. (Petit et al., 1997).

\section{SITE 1094}

Site 1094 is located in a small sedimentary basin north of Bouvet Island. It was the highest latitude site drilled during Leg 177 and represents the southernmost anchor of sites drilled along a latitudinal transect across the ACC. The site is located in the southern part of the ice-free Antarctic Zone, but it was covered by sea ice during the last Ice Age and preceding glacial intervals. The water depth of $2808 \mathrm{~m}$ places the site within the core of CPDW.

Four APC holes were drilled to depths of 159.6 mbsf (Hole 1094A), $38.0 \mathrm{mbsf}$ (Hole 1094B), $73.1 \mathrm{mbsf}$ (Hole 1094C), and $171.1 \mathrm{mbsf}$ (Hole 1094D). The oldest sediments recovered are Pleistocene in age ( 1.4 to $1.5 \mathrm{Ma})$ and the section consists predominantly of olive-gray to gray diatom oozes, with minor and varying amounts of foraminifers, nannofossils, and siliciclastic mud. A continuous spliced section was constructed to $\sim 121 \mathrm{mcd}$, representing the last $1 \mathrm{~m} . \mathrm{y}$, with one gap at the bottom of Core 177-1094A-7H.

Lithologic variations (as expressed in signals of magnetic susceptibility, GRA bulk density, color reflectance, and NGR) mirror in great detail the glacial and interglacial cycles of the late Pleistocene (Fig. 10). MISs 1-12 are readily identifiable in the upper 80 mcd. Glacial stages are marked by relatively high susceptibility, high NGR, low GRA bulk density, and low color 
reflectance (650-770 nm). Glacial terminations are marked by abrupt decreases of susceptibility and NGR and by increases in GRA bulk density and color reflectance. Sedimentation rates average $\sim 140 \mathrm{~m} / \mathrm{m}$.y. in the diatom dominated middle to upper Pleistocene sequence above $\sim 80$ mcd. Below MIS 12, sedimentation rates decreased to about $91 \mathrm{~m} / \mathrm{m} . \mathrm{y}$. during the early middle and early Pleistocene. The transition between the Brunhes and Matuyama Chrons is identified between 98.20 and 101.58 mcd in Hole 1094A.

Fragments of porcellanite (opal-CT) were recovered at $68 \mathrm{mbsf}$ (Holes 1094A and 1094D), 104 mbsf (Hole 1094A), and 164 mbsf (Hole 1094D), and a porcellanite concretion was found at $141 \mathrm{mbsf}$ (Hole 1094A). These layers were also detected in Parasound sediment echosounding lines and are characterized by distinct high-amplitude reflectors. The upper porcellanite occurs in the lower portion of MIS 11 and is the same as that previously described in piston cores from the area (Bohrmann et al., 1994). An anomalously low temperature gradient $\left(\sim 7^{\circ} / \mathrm{km}\right)$ was measured at Site 1094, indicating that these porcellanites formed under low (near-bottom-water) temperatures. The upper porcellanite (at $68 \mathrm{mbsf}$ ) coincides with a sharp discontinuity in interstitial chloride concentrations, suggesting that the porcellanite layer may have acted as a diffusion barrier. Shore-based geochemical analyses of pore-water and solid-phase samples taken from near these porcellanite beds will be important for studying early silica diagenesis in Site 1094.

The purpose of Site 1094 was to obtain a high-resolution record of biosiliceous sediments south of the present-day position of the Polar Front. Together with Sites $1089\left(41^{\circ} \mathrm{S}\right), 1091$ $\left(47^{\circ} \mathrm{S}\right)$, and $1093\left(50^{\circ} \mathrm{S}\right)$, Site $1094\left(53^{\circ} \mathrm{S}\right)$ represents the southernmost anchor of high-resolution sites across the ACC needed to reconstruct past changes in frontal boundaries and sea-ice distribution during glacial-interglacial cycles of the Pleistocene. The expanded upper and midPleistocene sediments at Site 1094 will permit study of rapid climate change on suborbital time scales, including comparison with paleoclimatic signals from Antarctic and Greenland ice cores. 
Leg 177

Preliminary Report

Page 34

\section{SUMMARY}

\section{Core Summary}

Approximately $4000 \mathrm{~m}$ of sediment ranging in age from middle Eocene to Holocene was recovered during Leg 177. To the extent possible, composite records were constructed at each site from cores in multiple holes by aligning features in the signals of core-logging data. Successful recovery was made of the following:

1. A latitudinal transect of Pleistocene sections across the ACC $\left(41^{\circ}-53^{\circ} \mathrm{S}\right)$, including Sites 1089 $\left(41^{\circ} \mathrm{S}\right), 1091\left(47^{\circ} \mathrm{S}\right), 1093\left(50^{\circ} \mathrm{S}\right)$, and $1094\left(53^{\circ} \mathrm{S}\right)$ (Fig. 11). Average sedimentation rates vary between 130 and 250 m/m.y., permitting studies at millennial-scale resolution (Fig. 12). Close to the base of three of these sites $(1089,1091$, and 1093) upper Pliocene sequences with sedimentation rates between 30 and $84 \mathrm{~m} / \mathrm{m} . \mathrm{y}$. were recovered.

2. Several Pliocene-Pleistocene sections with lower sedimentation rates averaging between 7 and 33 m/m.y., including Sites 1088 (41 $\left.{ }^{\circ} \mathrm{S}\right), 1090\left(43^{\circ} \mathrm{S}\right)$, and $1092\left(47^{\circ} \mathrm{S}\right)$.

3. Two relatively complete upper Miocene sequences at Sites $1088\left(41^{\circ} \mathrm{S}\right)$ and $1092\left(47^{\circ} \mathrm{S}\right)$ with sedimentation rates between $7-17$ and $30-38 \mathrm{~m} / \mathrm{m} . \mathrm{y}$. in the late to middle late Miocene and in the early late Miocene, respectively (Fig. 13). In conjunction with Leg 113 Sites 689 and 690, these sites represent an upper Miocene latitudinal transect across the Southern Ocean.

4. A lower Miocene to middle Eocene sequence ( 18 to $46 \mathrm{Ma})$ at Site $1090\left(43^{\circ} \mathrm{S}\right)$ that has a superb polarity reversal stratigraphy and was recovered in multiple holes to ensure a verifiably complete section.

5. Two depth transects of cores that intersect each of the major deep water masses in the Southern Ocean: (1) the Agulhas Ridge transect that includes Sites 1088 (2083 m), 1090 (3699 m), and 1089 (4624 m); and (2) the Meteor Rise transect that includes Site 1092 (1976 m), Leg 117 Site 704 (2532 m), and Site 1091 (4620 m). 
Leg 177

Preliminary Report

Page 35

\section{Lithostratigraphy}

Sediments of the Leg 177 sites are dominated by calcareous and siliceous biogenic components comprising foraminifers, nannofossils, diatoms and subordinate radiolarians, silicoflagellates, and sponge spicules (Fig. 14). Almost pure calcareous sediments were recovered at Sites 1088 and 1092 situated well above the regional CCD in intermediate water depths on the Agulhas Ridge (2083 m) and the Meteor Rise (1976 m). South of the Subantarctic Front, diatom-rich sediments predominate at Sites 1091 (4361 m), 1093 (3624 m), and 1094 (2808 m), within the circumantarctic opal belt. At all sites, the terrigenous sediment fraction mainly consists of siliciclastic silt and clay. At the southern Sites 1091-1094, sand- to gravel-sized ice-rafted detritus (IRD) represents a minor but ubiquitous constituent of the sediments.

Pelagic calcareous sediments at Site 1088 (Agulhas Ridge) consist of Quaternary foraminifer nannofossil ooze that grades into nannofossil ooze in Pliocene to middle Miocene sediments. Opal and siliciclastics represent minor components. Downhole lithological change is associated with an increase in clay-sized particles in the terrigenous fraction.

Site 1089 (4624 m) is located on a drift deposit at the northern flank of the Agulhas Ridge. Quaternary to Pliocene calcareous sediments contain the highest concentrations (up to 50\%) of terrigenous silt and clay encountered at Leg 177 sites, permitting the study of current strengths of paleo-bottom water. Lithological alternations between mud- and carbonate-rich sediments probably reflect sedimentary cycles attributed to glacial-interglacial cycles that triggered oscillations in carbonate production and/or terrigenous sediment supply.

At Site 1090 (3699 m) on the southern flank of the Agulhas Ridge, we recovered a 400-m-thick sediment succession that yields a long-term record of lithological and paleoenvironmental change from the Quaternary to the middle Eocene, interrupted by several hiatuses. A hiatus at 70 mcd, marked by a redeposited tephra layer and color change to redder sediments below, separates a Pleistocene to lower Pliocene calcareous ooze from lower Miocene sediments that are more opal- and mud-rich. The older sediments contain high opal concentrations (as much as $50 \%$ ) in the late Eocene. The lower part of the section is composed of zeolite-bearing calcareous 
Leg 177

Preliminary Report

Page 36

ooze of middle Eocene age.

In addition to Site 1088, Site 1092 on the Meteor Rise provides a low-sedimentation-rate record of pelagic calcareous deposits, spanning the Pleistocene to Miocene. The Quaternary part of the section reveals distinct variations in opal and siliciclastics, probably associated with glacial-interglacial cycles.

Sites 1091 and 1093 yielded diatom oozes deposited at high sedimentation rates from the Holocene to Pliocene. They represent typical pelagic deposits of the southern abyssal portion of the southeast Atlantic (Fig. 9). Distinct carbonate-rich intervals probably indicate peak interglacial periods, which were more frequent in the late Pleistocene to Pliocene record. At Site 1093, the Pliocene part of the section accumulated at lower sedimentation rates and is marked by an increase in terrigenous silts and clays. Several millimeter-thick marker beds, consisting of sand-sized foraminifer ooze, are intercalated in the section of Site 1091 and probably represent turbidites.

Rapidly deposited diatom ooze of Pleistocene age was also obtained at Site 1094, which was drilled in $2808 \mathrm{~m}$ of water in a small sedimentary basin north of Bouvet Island. In contrast to Sites 1091 and 1093, only a few carbonate-bearing intervals were found. Downhole lithological variations are marked by pronounced changes in the abundance of siliciclastics, as illustrated by fluctuations in magnetic susceptibility that show peak values in glacial intervals.

Four porcellanite horizons were penetrated at Site 1094 and form discrete layers as documented in Parasound seismograms. Porcellanite mainly is present as brownish amorphous fragments derived from the crushing of concrete porcellanite layers during coring, and also as individual loaf-shaped concretions, as much as $6 \mathrm{~cm}$ in diameter, exhibiting internal bedding structures that indicate an early diagenetic growth within the host sediment. Fragments of porcellanite were also found as cavings in cores of Site 1093. Shipboard X-ray diffraction (XRD) measurements indicate an opal-CT composition for the porcellanites. Joint investigations among Leg 177 scientists on the geochemical and mineralogical properties of porcellanite, pore-water, 
and host sediment composition in the context of regional heat flow and spatial distribution patterns of porcellanite layers will provide information on the conditions under which these young porcellanites formed.

Sediments from Sites 1091, 1093, and 1094 contain scattered IRD throughout the entire sections and should provide a high-temporal resolution record of past ice-rafting activity in response to terrestrial ice-sheet dynamics. IRD mainly consists of volcaniclastic particles along with minor quartz and crystalline rock fragments.

A significant proportion of the sediment at the southern Sites 1091, 1093, and 1094, which have the highest accumulation rates, consists of mats of the needle-like diatom Thalassiothrix. These diatom mats, which proved difficult to recover with the APC or XCB coring systems, occur as intervals of laminated sediment as much as $20 \mathrm{~m}$ thick (Fig. 15), as intermittently laminated sediment, or as bioturbated mat fragments or burrow-fills of mat material. Stratigraphically, this mat sediment is common in the transitions to and from interglacial, carbonate-rich sediment resulting in expanded sections in these intervals (e.g., the 5-m-thick MIS 12/11 boundary at Site 1093). At the two southernmost sites (1093 and 1094), diatom mats were recovered in the upper and mid-Pleistocene sediment. At Site 1091, located in the PFZ, the youngest diatom mats were noted at the lower/mid-Pleistocene boundary (Fig. 11). At both Sites 1091 and 1093, the most significant diatom mat sediment was deposited in the late early and mid-Pleistocene. Diatom mats also occur in the mid-Pliocene. The Leg 177 Thalassiothrix diatom mat deposits are remarkably similar to the vast Neogene laminated diatom mat deposits of the eastern equatorial Pacific Ocean (Kemp and Baldauf, 1993). Such deposits are thought to form beneath intense frontal zones (Kemp et al., 1995) and, in the Leg 177 sites, the Thalassiothrix mat intervals may track the paleoposition of the Southern Ocean frontal systems. These laminated sequences also represent a paleosediment trap that preserves individual flux events and provides the potential to generate pelagic records of climate/ocean change at key time intervals at a resolution that rivals that of ice cores. 
Leg 177

Preliminary Report

Page 38

\section{Biostratigraphy}

Primary age control points were provided by calcareous nannofossil, diatom, and radiolarian biostratigraphy, integrated in some sites with magnetostratigraphy. The calcareous nannofossil assemblages show a clear difference between the northern and southern sites, with an important decrease in diversity to the south. Datums previously calibrated in middle- and low-latitude areas were used for the Pleistocene time interval. A more accurate age model will provide the possibility to recalibrate these events and estimate their synchronism or diachronism. The Pliocene-Eocene time interval offers the opportunity to generate a new biostratigraphic scheme for the Southern Ocean, as well as to correlate these events with low-latitude data. Furthermore, cyclicity and assemblage alternations of the calcareous nannofossils are observed in abundance at all sites and ages, offering a potential tool for paleoceanographic investigations.

Paleoceanographic reconstructions using foraminifer-based stable isotopic results will be possible for most sites. Although the absolute abundance of both planktonic and benthic foraminifers is low in many cases, particularly at the southernmost deep-water sites, the high sedimentation rates in these areas have clearly increased the preservation of foraminifers. Radiolarian assemblages sharply change along the latitudinal transect, which makes it possible to clarify temporal and spatial distributions of radiolarian assemblages from mid- to high-latitude regions. Also, abundant radiolarians from high-resolution sites may allow us to obtain detailed paleoceanographic information such as opal productivity and sea-surface temperature (SST) changes. A detailed late Pliocene to Pleistocene biostratigraphic diatom zonation developed for subantarctic waters could be applied throughout almost the entire transect (Gersonde and Barcena, 1998). Diatom analyses of Leg 177 material provide a great potential to improve the diatom biostratigraphic zonation for the Southern Ocean. In particular, the diatom record of the Miocene-Eocene time interval, tied to a nearly continuous undisturbed paleomagnetic record, will provide a unique biostratigraphic zonation for the Paleogene epoch. Recovered material from the two southernmost sites located within the opal belt will allow reconstructions of paleoenvironmental parameters such as SST, by means of diatom transfer functions, and sea-ice occurrence, by diagnostic diatom taxa. 
Leg 177

Preliminary Report

Page 39

\section{Paleomagnetism}

All Leg 177 sites, with the exception of Site 1088, yielded magnetic polarity stratigraphies to augment other chronostratigraphic information. Of the high-sedimentation-rate sites, the primary magnetization was most clearly recorded at Sites 1089 and 1094. At the two other sites (1091 and 1093) with expanded sections, the magnetization is affected by secondary components that were not entirely removed by shipboard demagnetization treatments. Nonetheless, all four highresolution sites along the latitudinal transect have high potential for detailed (u-channel) studies of directional and bulk magnetic properties (Fig. 11). The objectives of these studies will be (1) to generate the first geomagnetic paleointensity records from the Southern Ocean for longdistance millennial-scale stratigraphic correlation; (2) to generate proxies for magnetic grain size and mineralogy that can be used for paleoenvironmental interpretation and to monitor detrital fluxes; and (3) to obtain detailed polarity transition records from the high-latitude Southern Hemisphere.

Sites 1090 and 1092, which are marked by lower sedimentation rates, both yielded welldefined magnetic stratigraphies, although the upper part of the section at both sites was severely compromised by drilling-related core deformation. Below about $60 \mathrm{mcd}$ at both sites, the shipboard magnetic polarity stratigraphies are well defined; however, correlation of polarity zones to the geomagnetic polarity time scale is ambiguous in the absence of detailed biostratigraphic analyses. Even in the XCB section of Site 1090, magnetic stratigraphies were well defined mainly because of the exceptional quality (lack of drilling deformation) of these cores. The middle Miocene to early Pliocene magnetostratigraphic record at Site 1092 and the exceptional Eocene to early Miocene record at Site 1090 will provide important new biomagnetostratigraphic correlations, and may allow orbital tuning of this part of the time scale.

\section{Whole-Core, Split-Core, and Downhole Logging Data}

Closely spaced measurements of sedimentary physical properties were obtained from all cores recovered during Leg 177, using the standard ODP whole-round MST. The Oregon State University split-core analysis track (OSU-SCAT) was deployed for diffuse color reflectance and resistivity measurements. Downhole logging data were obtained from Hole 1093D. 
Leg 177

Preliminary Report

Page 40

Measuring the cored sediments every 2 to $4 \mathrm{~cm}$ on the MST provided us with the highest temporal resolution data set collected during Leg 177. Physical properties are a function of sediment composition, structure, and porosity. Moreover, they are a tool for hole-to-hole correlations and comparisons among sites. Glacial-interglacial fluctuations in sediment composition were observed in GRA bulk density. High values in sediments at the northern sites are consistent with overall high carbonate contents, particularly in interglacial intervals. High percentages of biogenic opal (high porosity) result in a decrease of sediment bulk density during interglacials at the southern Sites 1093 and 1094. The opposite is observed in the alternating glacial deposits that have higher terrigenous percentages. At Site 1094, magnetic susceptibility and NGR show high signal amplitudes, but with different character. The shape of magnetic susceptibility is rectangular, whereas NGR displays an asymmetric, sawtooth pattern with highest intensities toward the end of glacial periods (Fig. 10). This indicates that both signals contain different information regarding terrigenous sediment components. Signal cyclicities are strongly developed in the Pleistocene sequences at Sites 1089, 1091, 1093, and 1094, and also in the continuous early Miocene to late Eocene sequence at Site 1090. These cyclic variations in lithologic parameters may permit the development of orbitally tuned age models in conjunction with biomagneto- and stable-isotope stratigraphies.

Diffuse spectral reflectance measurements obtained from the SCAT and the Minolta CM-2002 photospectrometer contributed greatly to the overall success of the leg, providing high-resolution lithostratigraphic records in real time. These data provided important stratigraphic constraints for hole-to-hole correlation during the generation of shipboard spliced composite sections. At Sites 1088, 1089, and 1092, interglacial carbonate-bearing sediments were easily discernible from darker, diatom-rich glacial sediments. The spectral reflectance signals were especially important for correlation of the biosiliceous oozes at Sites 1091, 1093, and 1094, where magnetic susceptibility signals dropped below measurable values during interglacials. Records of reflectance also proved extremely useful as geochronologic tools during Leg 177. In conjunction with biostratigraphic and magnetostratigraphic datums, preliminary estimates of MISs were inferred on the basis of sediment brightness (Fig. 16). 
Some of the oldest sediments thus far measured for diffuse spectral reflectance were recovered in the Miocene to Eocene sequences from Sites 1088, 1090, and 1092. The continuous lower Miocene to upper Eocene sequence at Site 1090 is noteworthy for the high-amplitude SCAT signal in the APC cores that span from early Miocene to Oligocene time, as well as in the deeper XCB sequence from which the cores were measured with the CM-2002 photospectrometer (Fig. 17). Leg 177 spectral reflectance records hold great potential for development of high-resolution age models and proxy estimation of sediment mineralogy.

\section{Pore-Water Geochemistry}

The pore-water chemistry of Leg 177 sites can be divided into two broad categories: (1) sites with a high biogenic carbonate content, low biosiliceous content, and low sedimentation rates (10-30 m/m.y.) that are located to the north of the PFZ (Sites 1088, 1090, and 1092) and (2) sites with low carbonate content, high opal content, and high sedimentation rates $(140-250 \mathrm{~m} / \mathrm{m} . \mathrm{y}$.) that are located within or to the south of the PFZ (Sites 1091, 1093, and 1094). The pore-water geochemistry of the carbonate-rich sites is, in general, quite similar to that of many other carbonate-rich sites drilled on previous ODP and DSDP legs, that is, oxic to suboxic sediments with ample evidence for carbonate diagenesis occurring at depth. The closely spaced interstitial water sampling employed during Leg 177 will permit more detailed analyses of some interesting features observed from these carbonate-rich sites. However, the highlight of the pore-water geochemistry obtained during Leg 177 derives from the unique (and still somewhat enigmatic) results observed at sites with sequences dominated by diatom ooze deposited at high sedimentation rates within or south of the PFZ, and also from the early diagenetic porcellanites (opal-CT) observed at Site 1094. The collection of a series of closely-spaced $(1.5 \mathrm{~m})$ interstitial water samples across several of the porcellanite intervals should provide important insights into the formation of these early porcellanites.

A synthesis of several pore-water profiles from Sites 1091, 1093, and 1094 are shown in Figure 18. The chloride profiles show clear evidence for the downward diffusion of higher salinity glacial-age seawater (McDuff, 1985). The uppermost porcellanite layer at about $68 \mathrm{mbsf}$ at Site 
Leg 177

Preliminary Report

Page 42

1094 has apparently interrupted this downward diffusion and presents the intriguing suggestion that the porcellanite may have formed in the past 10 to $20 \mathrm{k} . \mathrm{y}$. These high-sedimentation-rate diatomaceous oozes were suboxic to mildly reducing. H2S was detected by smell at Sites 1091 and 1093 throughout most of these profiles, but H2S was not detected at all at Site 1094 except for a very faint whiff in one whole round near the top of the section. In addition, sulfate depletion is much lower than would be expected based on sedimentation rate, and it appears to be inversely correlated with our preliminary estimates of TOC (see site chapters for data not shown here).

Phosphate profiles show little correlation with alkalinity and ammonium except at Site 1094, and dissolved manganese $(\mathrm{Mn})$ is observed to varying degrees throughout the profiles. We offer the following preliminary interpretation of these observations. The highest sedimentation-rate site is Site 1093 ( $25 \mathrm{~cm} / \mathrm{k} . \mathrm{y}$.$) , which is located very near the contemporaneous Polar Front at \sim 50^{\circ} \mathrm{S}$. Sedimentation rates at Site 1093 were likely least affected by glacial-interglacial migrations of the Polar Front compared to Sites 1091 and 1094 located about $3^{\circ}$ to the north and south, respectively. Thus, the mildly reducing conditions at Site 1093 have likely persisted through glacial-interglacial cycles as evidenced by the low downcore dissolved Mn profile. Sites 1091 and 1094 have undergone much more drastic perturbations in average sedimentation rates (both $\sim 14 \mathrm{~cm} / \mathrm{k} . y$.) and are out of phase with each other over the glacial-interglacial climate cycles. This resulted in a periodicity in the redox state of the sediments that has somehow permitted reactive $\mathrm{Mn}$ to persist at depth. The low sulfate reduction rates observed despite the high sedimentation rates may result from the fact that a significant, if not major, fraction of the organic carbon in these diatomaceous oozes is highly refractory opal-intrinsic organic carbon that is unavailable for degradation until the opal has dissolved. Opal-intrinsic organic carbon likely has a very low phosphate content, thus offering some explanation for the nature of the phosphate profiles observed in these diatomaceous oozes.

In summary, this preliminary and general interpretation of these first deep interstitial water profiles from the circumantarctic siliceous ooze belt will need to be verified and enhanced with additional shore-based analyses. Additionally, shore-based analyses of closely spaced interstitial water samples across some of the porcellanite intervals observed in the sediments at Site 1094 
may offer important insight into the mechanisms involved in the transformation of diatom opal to opal-CT.

\section{Future Work}

Approximately $4000 \mathrm{~m}$ of sediment was recovered during Leg 177 on a north-south transect across the ACC needed to study the paleoceanographic history of the southeast Atlantic sector of the Southern Ocean on a variety of time scales, including suborbital (102 to $103 \mathrm{yr}$, decadal to millennial), orbital (104 to $105 \mathrm{yr}$, Milankovitch), and long term (105 to $106 \mathrm{yr}$, Cenozoic). Postcruise research will focus on generating signals of faunal, isotopic, and sedimentologic paleotracers that will be used to study the role played by the Southern Ocean in the global climate system.

Undoubtedly, one of the most exciting results of Leg 177 was the successful recovery of expanded sequences arrayed across the ACC from $41^{\circ}$ to $53^{\circ} \mathrm{S}$ (Fig. 11). Average sedimentation rates during the Pleistocene varied from $132 \mathrm{~m} / \mathrm{m}$.y. at Site 1089, to $140 \mathrm{~m} / \mathrm{m}$.y. at Site 1094, 145 $\mathrm{m} / \mathrm{m}$.y. at Site 1091, and $250 \mathrm{~m} / \mathrm{m} . \mathrm{y}$. at Site 1093. Detailed sampling and measurements of proxy variables in these cores will permit us to reconstruct changes in paleotracers and lithology on time scales of hundreds to thousands of years. For example, we intend to use isotopic, faunal, and sedimentologic methods to reconstruct changes in the position of the oceanic frontal systems of the ACC, and diatom sea-ice indicators to assess changes in sea-ice distribution during glacial-to-interglacial cycles of the Pliocene-Pleistocene interval. Foraminifer, diatom, and radiolarian transfer functions as well as UK37' temperature estimations will be used to reconstruct variations in past SST. Accumulation rates of carbonate, opal, and organic matter, as well as stable-isotope studies, radiotracer studies, and microfossil distribution patterns will be used to study variation in productivity and export production of the Southern Ocean. Faunal, isotopic, and trace-element studies of benthic-foraminifer and clay-mineral distribution will be used to study changes in deep-water masses, including the variable input of NADW into the Southern Ocean during glacial-to-interglacial cycles. Variations in coarse-grained IRD, magnetic properties, sediment particle size and geochemistry, and clay mineralogy will be used to study variations in the accumulation rate, source, and transport (aeolian, ice rafted, or bottom water) of 
Leg 177

Preliminary Report

Page 44

terrigenous material. These studies will produce multi-proxy data sets for the reconstruction of the interglacial and glacial modes of Southern Ocean surface and deep circulation. They will also provide insight into the impact of Southern Ocean paleoceanographic variability on global ocean biochemical cycles and atmospheric gas concentrations $\left(\mathrm{CO}_{2}\right)$, as well as on past current-velocity rates, wind fields, and the stability of the Antarctic ice sheets.

The high temporal resolution of Leg 177 sediments will permit detailed correlation of paleotracer signals with those from other rapidly deposited sediment cores from the North Atlantic (Legs 162 and 172) and with ice-core records from Greenland, Antarctica, and tropical glaciers. Leg 177 sediments will be used to study the origin of millennial-scale climate variability that was first recognized in ice cores on Greenland (Daansgard et al., 1993) but now appears to be manifested globally (Broecker, 1997). A particularly interesting time period recovered in Leg 177 sediments is MIS 11 (423 to $363 \mathrm{ka}$ ), which is marked in all sites by white, carbonate-rich sediments that display the highest values in color reflectance (Fig. 16). MIS 11 was one of the warmest periods of the late Pleistocene, and the Polar Front may have been further south than during succeeding interglacials (Howard, 1997). The transition from MIS 12 to 11 (Termination V) represents the largest change in oxygen isotopic values during the late Pleistocene, yet insolation forcing at $65^{\circ} \mathrm{N}$ was very weak during this termination ("Stage 11 problem" of Imbrie et al., 1993). What role did the Southern Ocean play in Termination V? Leg 177 scientists will take a multi-proxy approach to addressing this question by generating detailed stable-isotope, geochemical, faunal, and sedimentological paleotracers in the transect of highsedimentation-rate cores across the ACC. Another time period of great interest is MIS 5, which was recovered in Leg 177 cores with a total thickness of up to $15 \mathrm{~m}$. This includes up to $\sim 3 \mathrm{~m}$ of sediment in several cores representing Substage 5.5 (Eemian), which show significant variations in sedimentary physical properties that are tentatively interpreted to represent environmental change. Detailed studies can elucidate the stability of climate conditions during the last climatic optimum and other interglacial stages, including the Holocene, which remains a controversial issue in the light of results from the Greenland Ice-core Project (GRIP, 1993).

Studying the response of the Southern Ocean to orbital forcing and determining the phase 
relationships to climatic changes in other regions is important for assessing the role that the Antarctic region played in glacial-to- interglacial cycles of the late Pleistocene. Only the combination of marine, terrestrial, and atmospheric paleoclimatic records from key areas on our globe will elucidate the mechanisms driving global climate. As such, the expanded sequences recovered during Leg 177 provide much needed deep-sea records from the southern high latitudes for such global comparisons.

Important questions that now can be addressed with the Pleistocene sequences recovered during Leg 177 include the following: Is there evidence for millennial-scale variability in SST and sea ice in the Southern Ocean? If so, how does it relate to short-term climatic events recorded in Antarctic and Greenland ice cores? What role does Antarctic sea ice play in internal feedback mechanisms driving rapid climate change? Sea ice represents a fast-changing environmental parameter with multiple impacts on Earth's heat budget, oceanic and atmospheric circulation, and export productivity. Did pulse-like surges occur in the Antarctic Ice Sheet during the late Pleistocene, and is there a record of these events preserved in the Southern Ocean sediments, similar to the Heinrich events preserved in the North Atlantic? What was the nature and structure of terminations in the Southern Hemisphere during the late Pleistocene? What role did thermohaline circulation (NADW flux to the Southern Ocean) play in coupled ice-sheet and ocean oscillations on millennial and longer time scales? To what extent do processes in the Southern Ocean control atmospheric $\mathrm{CO}_{2}$ variations? What is the phase relationship between millennial-scale climate change in the high-latitude Southern and Northern Hemispheres, and what is the mechanism linking climate in the polar regions? Could the paleoclimatic record of the southern high latitudes represent a potential forecast for future millennial-to-centennial climate change during the Holocene (Howard and Prell, 1992; Labeyrie et al., 1996)?

At about $900 \mathrm{ka}$, a shift occurred in the dominant power of climatic variability from 41 to 100 k.y., the so-called Mid-Pleistocene Revolution (MPR; Berger and Jansen, 1994). The MPR has not been well studied from the Southern Ocean because sediments are disturbed in the only existing record of this event at ODP Site 704 (Hodell and Venz, 1992). Interestingly, between 0.7 and 1.6 Ma the area of the present PFZ is characterized by deposition of laminated diatom 
Leg 177

Preliminary Report

Page 46

mats deposited at high sedimentation rates, as documented in Sites 1091 and 1093 (Fig. 11). What was the role of the Southern Ocean in the shift from 41-k.y. to 100-k.y. climatic variability? Was the phase relationship between the polar oceans different during the 41-k.y. world of the early Pleistocene compared to the 100-k.y. world of the late Pleistocene? How is the fast deposition of biosiliceous deposits at the transition in the late early Pleistocene linked with the MPR? To address these questions, groups of Leg 177 scientists will focus on the 100-k.y. world, 41-k.y. world, and MPR in Leg 177 sediments using multi-proxy approaches.

Although early and early late Pliocene sequences were recovered partially at only a few sites (Sites 1088, 1090, 1092, and 1093) during Leg 177, combined isotopic and microfossil distribution studies of these sediments may contribute to the debate of the extent and volume of the Antarctic ice sheet during the early-late Pliocene. There are those who assume an essentially stable, combined East and West Antarctic ice sheet since the early Pliocene (Kennett and Barker, 1990; Clapperton and Sugden, 1990), and those who envision a highly dynamic Antarctic ice sheet during the early and early-late Pliocene (Webb and Harwood, 1991; Hambrey and Barrett, 1993). Shipboard diatom studies on Leg 177 sequences indicate changes in surface-water parameters during the early-late Pliocene transition. Although sequences assigned to the upper Gauss Chron contain assemblages reflecting rather glacial-type conditions, the lower Gauss Chron sequences are characterized by warm-water diatoms, such as the Hemidiscus ooze found in Site 1091. This preliminary result may suggest that the mid-Pliocene was punctuated by a time period of significant warming, as suggested by Dowsett et al. (1996). Pliocene sediments will also be scanned for traces of the Eltanin asteroid impact that occurred 2.15 Ma in the Southern Ocean (Bellingshausen Sea) to constrain the maximum size of the bolide that is now estimated to have been at least $1 \mathrm{~km}$ in diameter (Gersonde et al., 1997).

Two upper Miocene sequences were recovered at Sites 1088 and 1090, forming a latitudinal transect across the Southern Ocean in conjunction with Leg 113 Sites 689 and 690 (Maud Rise). At both sites, the late and middle late Miocene ( 5.3-9 Ma) is marked by low sedimentation rates ( $\sim 15-17 \mathrm{~m} / \mathrm{m} . \mathrm{y}$.$) and the early late Miocene by higher rates (almost double). Similar upper$ Miocene sequences were recorded during Legs 113, 114, and 119 (Gersonde et al., 1990; 
Ciesielski, Kristoffersen, et al., 1988; Barron et al., 1991). The high early late Miocene sedimentation rates can be related to a distinct cooling period accompanied with a significant drop in sea level (Fig. 19), succeeded by several less intense warming and cooling periods in the middle and late late Miocene (Barron et al., 1991). Combined isotope and microfossil analysis will focus on late Miocene climate evolution on this latitudinal transect, and may elucidate the waxing and waning of the Antarctic ice sheets during this interval. Evidence of cyclicity in the Milankovitch frequency band at Site 1092 may permit the development of an astronomically tuned time scale (Shackleton and Crowhurst, 1997) that will provide a detailed chronology of upper Miocene changes in surface- and deep-water circulation.

The Cenozoic objectives of Leg 177 will be addressed mainly at Site 1090. This site contains a lower Miocene to middle Eocene sequence that is remarkable for several reasons: (1) a verifiably complete spliced section was constructed using three holes spanning in age from the early Oligocene to early Miocene; (2) the co-occurrence of well-preserved calcareous and siliceous microfossils throughout most of the section will allow intercalibration of foraminifer, calcareous nannofossil, diatom, silicoflagellate, and radiolarian biostratigraphies; (3) the paleomagnetic inclination records indicate clearly defined polarity zones throughout the sequence, offering the potential of a magnetic time scale after correlation of the reversal pattern to the geomagnetic polarity time scale with the aid of detailed shore-based biostratigraphy; (4) the development of geomagnetic paleointensity and/or reversal records may provide long-distance stratigraphic correlation; (5) cyclic variations in lithologic parameters may permit the development of an astronomically tuned time scale for the Oligocene to early Miocene; and (6) the shallow burial depth ( $<370 \mathrm{mbsf}$ ) of the section offers an opportunity to produce reliable stable-isotope stratigraphies that have not been compromised by diagenetic alteration.

Approximately $330 \mathrm{~m}$ of sediment was recovered below the hiatus at $70 \mathrm{mcd}$ at Site 1090, ranging in age from the early Miocene to middle Eocene. Sedimentation rates averaged 10 $\mathrm{m} / \mathrm{m}$.y. in the early Miocene and the middle Eocene, and increased to $30 \mathrm{~m} / \mathrm{m}$.y. during the deposition of opal-rich sediments in the late Eocene that include intervals of well-laminated diatom ooze. The spliced Oligocene-early Miocene section at Site 1090 complements the 
Leg 177

Preliminary Report

Page 48

records obtained during Leg 154 (Sites 925, 926, 928, and 929), and comparisons among these records can be used to test orbitally tuned time scales (Weedon et al., 1997), study Milankovitchscale cyclicity of paleotracers during the late Paleogene-early Neogene (Zachos et al., 1997), and calibrate biostratigraphic datums to the geomagnetic polarity time scale. Furthermore, Site 1090 will be used to study major paleoceanographic changes in the Southern Ocean during the middle Eocene to early Miocene. Combined with the results from Paleogene sections recovered on Maud Rise during Leg 113 (Kennett and Barker, 1990), Site 1090 provides a unique opportunity to study major paleoceanographic changes in the Southern Ocean from the middle Eocene to early Miocene (Fig. 19). This will include the development and intensification of Southern Ocean thermal isolation and the ACC, the related growth of the East Antarctic Ice Sheet (Zachos et al., 1992), and their relation to the changing paleogeography of the high-latitude Southern Hemisphere (Lawver et al., 1992). 
Leg 177

Preliminary Report

Page 49

\section{REFERENCES}

Baldauf. J.G., Barron, J.A., Ehrmann, W.U., Hempel, P., and Murray, D., 1992. Biosiliceous sedimentation patterns for the Indian ocean during the last 45 Million years. Geophys Monogr., 70:335-349.

Barker, P.F., 1979. The history of ridge-crest offset at the Agulhas Fracture zone from a smallcircle geophysical profile. Geophys. J. R. Astr. Soc., 59: 131-145.

Barrett, P.J., 1994. Progress towards a Cenozoic Antarctic glacial history. Terra Antarctica, 1:247-248.

Barron, J.A., Baldauf, J.G., Barrera, E., Caulet, J.-P., Huber, B.T., Keating, B.H., Lazarus, D., Sakai, H., Thierstein, H.R., and Wei, W., 1991b. Biochronologic and magnetochronologic synthesis of Leg 119 sediments from the Kerguelen Plateau and Prydz Bay, Antarctica. In Barron, J., Larsen, B., et al., Proc. ODP, Sci. Results, 119: College Station, TX (Ocean Drilling Program), 813-848.

Bender, M., T. Sowers, M. Dickson, J. Orchardo, P. Grootes, P. Mayewski and D. Messe, 1994. Climate teleconnections between Greenland and Antarctica throughout the last 100,000 years. Nature, 372: 663-666.

Berger, W. H., 1989. Global maps of ocean productivity. In: Berger, W. H., Smetacek, V. S. and G. Wefer (Eds.), Productivity in the ocean: Present and Past, Dahlem Workshop Reports LS44, Wiley \& Sons, 429-456.

Berger. W.H. and Jansen, E., 1994. Mid-Pleistocene climate shift — the Nansen connection. In Johannessen, O.M., Muench, R.D., and Overland, J.E. (Eds.), The Polar Oceans: and Their Role in Shaping the Global Environment, Geophysical Monograph 85, Washington (American Geophysical Union), 295-312.

Bohrmann, G., Abelmann, A., Gersonde, R., Hubberten, H. and Kuhn, G., 1994. Pure siliceous ooze, a diagenetic environment for early chert formation. Geology, 22:207-210.

Bohrmann, G., Kuhn, G., Abelmann, A., Gersonde, R., and D. Fütterer, 1990. A young porcellanite occurrence from the Southwest Indian Ridge. Marine Geology, 92:155-163

Bonatti, E., 1978. Vertical tectonism in oceanic fracture zones. Earth Planet. Sci. Lett., 37:369379. 
Leg 177

Preliminary Report

Page 50

Bond, G., Broecker, W., Johnsen, S., McManus, J., Labeyrie, L., Jouzel, J., and Bonani, G., 1993. Correlation between the climatic record in northern Atlantic marine sediment and in Greenland ice. Nature, 365:143-147.

Bond, G.C. and Lotti, R., 1995. Detailed record of iceberg discharges into the northern Atlantic. Science, 267:1005-1010.

Broecker, W.S. 1997. Will our ride into the Greenhouse future be a smooth one? GSA Today, 7:1-6.

Broecker, W.S. and Peng, T.H., 1989. The cause of glacial to interglacial atmospheric $\mathrm{CO}_{2}$ change: a polar alkalinity hypothesis. Global Biogeochem. Cycles, 3:215-240.

Cande, S.C., LaBrecque, J.L. and Haxby, W.F., 1988. Plate kinematics of the South Atlantic: Chron c34 to present. J. Geophys. Res., 93:13479-13492.

Cande, S.C. and Kent, D.V., 1992. A new geomagnetic polarity time scale for the Late Cretaceous and Cenozoic. J. Geophys. Res., 97:13917-13951.

Charles, C.D. and Fairbanks, R.G., 1992. Evidence from Southern Ocean sediments for the effect of North Atlantic deep-water flux on climate. Nature, 355:416-419.

Charles, C.D., Lynch-Stieglitz, J., Ninnemann, U.S. and Fairbanks, R.G., 1996. Climate connections between the hemispheres revealed by deep sea sediment core/ice core correlations. Earth Planet. Sci. Lett., 142:19-27.

Ciesielski, P.F., Kristoffersen, Y., et al., 1988. Proc. ODP, Init. Repts., 114: College Station, TX (Ocean Drilling Program).

Clapperton, C.M., and Sugden, D.E., 1990. Late Cenozoic glacial history of the Ross Embayment, Antarctica. Quat. Sci. Rev., 9:253-272.

Dansgaard, W., Johnsen, S.J., Clausen, H.B., Dahl-Jensen, D., Gundestrup, N.S., Hammer, C.U., Hvidberg, C.S., Steffensen, J.P., Sveinbjårnsdottir, A.E., Jouzel, J., and Bond, G., 1993. Evidence for general instability of past climate from a 250-kyr ice-core record. Nature, 364:218-220.

DeMaster, D. J., 1981. The supply and accumulation of silica in the marine environment. Geochim. Cosmochim. Acta, 45:1715-1735. 
Douglass, J., Schilling, J.-G., Kingsley, R.H. and Small, C., 1995. Influence of the Discovery and Shona mantle plumes on the southern Mid-Atlantic Ridge: Rare earth evidence. $J$. Geophys. Res., 21: 2893-2396.

Dowsett, H., Barron, J. and Poore, R., 1996. Middle Pliocene sea surface temperatures: a global reconstruction. Marine Micropaleo., 27:13-25.

du Plessis, A., 1977. Seafloor spreading south of the Agulhas Fracture Zone. Nature, 270: 719721.

Frank, M., Gersonde, R., Rutgers van der Loeff, M., G. Kuhn, and Mangini, A., 1996. Late Quaternary sediment dating and quantification of lateral sediment redistribution applying 230Thex: a study from the eastern Atlantic sector of the Southern Ocean. Geologische Rundschau, 85:554-566.

Francois, R., Altabet, M.A., Ein-Fen, Y., Sigman, D.M., Bacon, M.P., Frank, M., Bohrmann, G., Bareille, G. and Labeyrie, L.D., 1998. Contribution of Southern Ocean surface-water stratification to low atmospheric $\mathrm{CO}_{2}$ concentrations during the last glacial period. Nature, 389:929-935.

Froelich, P.N., Malone, P.N., Hodell, D.A., et al., 1991a. Biogenic opal and carbonate accumulation rates in the subantarctic South Atlantic: The late Neogene of Meteor Rise Site 704. In Ciesielski, P.F., Kristoffersen, Y., et al., Proc. ODP, Sci. Results., 114: College Station, TX (Ocean Drilling Program), 515-550.

Froelich, P.N., Mortlock, R.A., Mefferd, M., and Powers, J., 1991b. Interstitial-water chemistry: Abyssal South Atlantic and East Georgia Basins, Islas Orcadas and Meteor Rises. In Ciesielski, P.F., Kristoffersen, Y., et al., Proc. ODP, Sci. Results., 114: College Station, TX (Ocean Drilling Program), 719-731.

Gersonde, R., Abelmann, A., Burckle, L.H., Hamilton, N., Lazarus, D., McCartney, K., O'Brien, P., Spieß, V., and Wise, S.W., Jr., 1990. Biostratigraphic synthesis of Neogene siliceous microfossils from the Antarctic Ocean, ODP Leg 113 (Weddell Sea). In Barker, P.F., Kennett, J.P., et al., Proc. ODP, Sci. Results, 113: College Station, TX (Ocean Drilling Program), 915-936.

Gersonde, R.,, Kyte, F. T., Bleil, U., Diekmann, B., Flores, J.A., Gohl, K., Grahl, G., Hagen, R., Kuhn, G., Sierro, F.J., Voelker, D., Abelmann, A., and Bostwick, J. A., 1997. Geological 
Leg 177

Preliminary Report

Page 52

record and reconstruction of the late Pliocene impact of the Eltanin asteroid in the Southern Ocean. Nature, 390, 357-363.

Gersonde, R. and Barcena, M.A., 1998. Revision of the latePliocene-Pleistocene diatom biostratigraphy for the northern belt of the Southern Ocean. Micropaleontology, 44:1-15.

GRIP (Greenland Ice-core Project) Members, 1993. Climate instability during the last interglacial period recorded in the GRIP ice core. Nature, 364:203-207.

Hambrey, M.J., and Barrett, P.J., 1993. Cenozoic sedimentary and climatic record, Ross Sea Region, Antarctica. In Kennett, J.P., and Warnke, D.A., (Eds.), The Antarctic Paleoenvironment: A Perspective on Global Change, 2. Antarct. Res. Ser., 60: 91-124. Hartnady, C.J.H. and le Roex, A.P., 1985. Southern ocean hotspot tracks and the Cenozoic absolute motion of the African, Antarctic, and South American plates. Earth Planet. Sci. Lett., 75: 245-257.

Henson, E.L. and Ruppel, C., in press. Plate tectonics and loading history of the South Atlantic between the Agulhas Fracture Zone and the Bouvet triple junction. J. Geophys. Res.

Hodell, D.A. and Venz, K.A., 1992. Toward a high-resolution stable isotopic record of the Southern Ocean during the Pliocene-Pleistocene (4.8 to 0.8 Ma). In: Kennett, J.P. and Warnke, D.A., The Antarctic Paleoenvironment: A Perspective on Global Change, 56: Washington, DC (American Geophysical Union), 265-310.

Howard, W.R., 1997. A warm future in the past. Nature, 388: 418-419.

Howard, W.R. and W.L. Prell, 1992. Late Quaternary surface circulation of the southern Indian Ocean and its relationship to orbital variations. Paleoceanography, 7(1): 79-117.

Howard, W.R. and W.L. Prell, 1994. Late Quaternary $\mathrm{CaCO}_{3}$ production and preservation: Implications for oceanic and atmospheric carbon cycling. Paleoceanography, 9(3):453482.

Imbrie, J., Berger, A., Boyle, E.A., Clemens, S.C., Duffy, A., Howard, W.R., Kukla, G., Kutzbach, J., Martinson, D.G., McIntyre, A., Mix, A.C., Molfino, B., Morley, J.J., Peterson, L.C. Pisias, N.G., Prell, W.L., Raymo, M.E., Shackleton, N.J., and Toggweiler, J.R., 1993. On the structure and origin of major glaciation cycles, 2. The 100,000-year cycle. Paleoceanography, 8:699-735. 
Imbrie, J., Boyle, E.A., Clemens, S.C., Duffy, A., Howard, W.R., Kukla, G., Kutzbach, J., Martinson, D.G., McIntyre, A., Mix, A.C., Molfino, B., Morley, J.J., Peterson, L.C. Pisias, N.G., Prell, W.L., Raymo, M.E., Shackleton, N.J., and Toggweiler, J.R., 1992. On the structure and origin of major glaciation cycles 1. Linear responses to Milankovitch forcing. Paleoceanography, 7:701-738.

Imbrie, J.A., McIntyre, A. and Mix, A., 1989. Oceanic response to orbital forcing in the late Quaternary: Observational and experimental strategies. In: Berger, A., Schneider, S., and Duplessy, J.C. (Eds.), Climate and Geosciences, Boston (Kluwer), 121-164.

Kastens, K.A., 1987. A compendium of causes and effects of processes at transform faults and fracture zones. Rev. Geophys., 25:1554-1562.

Keir, R. S., 1988. On the late Pleistocene ocean geochemistry and circulation. Paleoceanography, 3:413-445.

Kennett, J.P. and Barker, P.F., 1990. Latest Cretaceous to Cenozoic climate and oceanographic developments in the Weddell Sea, Antarctica: an ocean-drilling perspective. In Barker, P.F., Kennett, J.P., et al., Proc. ODP, Sci. Results, 113: College Station, TX (Ocean Drilling Program), 937-960.

Kemp, A.E.S. and Baldauf, J.G., 1993. Vast Neogene laminated diatom mat deposits from the eastern equatorial Pacific Ocean. Nature, 362: 141-144.

Kemp, A.E.S., Baldauf, J.G. and Pearce, R.B., 1995. Origins and palaeoceanographic significance of laminated diatom ooze from the eastern equatorial Pacific Ocean (Leg 138), Proc. ODP, Sci. Results, 138: College Station, TX (Ocean Drilling Program), 641-645.

Kennett, J. P., 1977. Cenozoic evolution of Antarctic glaciation, the Circum-Antarctic Ocean, and their impact on global paleoceanography, J. Geophys. Res. 82:3843-59.

Kennett, J.P. and Barron, J.A., 1992. Introduction In: Kennett, J.P. and Warnke, D.A. (eds.), The Antarctic Paleoenvironment: A Perspective on Global Change, 56: Washington, DC (American Geophysical Union), 1-6.

Knox, F.E. and McElroy, M.B., 1984. Changes in atmospheric $\mathrm{CO}_{2}$ : Influence of the marine biota at high latitudes, J. Geophys. Res., 89: 4629-4637. 
Leg 177

Preliminary Report

Page 54

Kumar, K., Anderson, R.F., Mortlock, R.A., Froelich, P.N., Kubik, P., Dittrich-Hannen, B. and Suter, M., 1995. Increased biological productivity and export production in the glacial Southern Ocean. Nature, 378: 675-680.

Labeyrie, L., Pichon, J.-J., Labracherie, M., Ippolito, P., Duprat, J. and Duplessy, J.-C., 1986.

Melting history of Antarctica during the past 60,000 years. Nature, 322: 701-706.

Labeyrie, L., Labracherie, M., Gorfti, N., Pichon, J..J., Vautravers, M., Arnold, M., Duplessy, J.-

C., Paterne, M. Michel, E., Duprat, J., Caralp, M. and Turon, J. L., 1996. Hydrographic changes of the Southern Ocean (southeast Indian sector) over the last $230 \mathrm{kyr}$.

Paleoceanography, 11: 57-76.

LaBrecque, J.L. (Ed.), 1986. South Atlantic Ocean and Adjacent Continental Margins, Atlas 13. Ocean Margin Drilling Program Atlas Ser., 13.

LaBrecque, J.L. and Hayes, D.E., 1979. Seafloor spreading history of the Agulhas Basin. Earth Planet. Sci. Lett., 45:411-428.

Lawver, L.A., Gahagan, L.M. and Coffin, M.F., 1992. The development of paleoseaways around Antarctica. In Kennett, J.P. and Warnke, D.A. (Eds.), The Antarctic Paleoenvironment: A Perspective on Global Change, 56: Washington, DC (American Geophysical Union), 730.

Lisitzin, A. P., 1985. The silica cycle during the last ice age. Paleogeogr. Palaeoclimatol. Palaeoecol., 50:241- 270.

Lutjeharms, J.R.E., 1985. Location of frontal systems between Africa and Antarctica: some preliminary results, Deep-Sea Research 32:1499-1509.

McDuff, R.E., 1985. The chemistry of interstitial waters, Deep Sea Drilling Project Leg 86. In Heath, G.R., Burkle, L.H., et al., Init. Repts. DSDP, 86: Washington (U.S. Govt. Printing Office), 675-687.

Menard, H.W. and Atwater, T., 1969. Origin of fracture zone topography. Nature, 222: 10371040.

Morley, J.J., 1989. Variations in high-latitude oceanographic fronts in the southern Indian Ocean: an estimation based on faunal changes. Paleoceanography, 4(5):547-554. 
Mutter, J.C., Buck, W.R. and Zehnder, C.M., 1988. Convective partial melting, 1: A model for the formation of thick basaltic sequences during the initiation of spreading. J. Geophys. Res., 93:1031-1048.

Oppo, D.W. and Fairbanks, R.G., 1987. Variability in the deep and intermediate water circulation of the Atlantic Ocean during the past 25,000 years: Northern Hemisphere modulation of the Southern Ocean. Earth Planet. Sci. Lett., 86:1-15.

Peterson, R.G. and Stramma, L., 1991. Upper-level circulation in the South Atlantic Ocean. Prog. Oceanog., 26:1-73.

Petit, J.R., Basile, I., Leruyuet, A., Raynaud, D., Lorius, C., Jouzel, J., Stievenard, M., Lipenkov, V.Y., Barkov, N.I., Kudryashov, B-B., Davis, M., Saltzman, E., and Kotlyakov, V., 1997. Four climatic cycles in Vostok ice core. Nature, 387:359.(Kluwer), 121-164.

Prell, W.L., Huston, W.H. and Williams, D.F., 1979. The Subtropical Convergence and late Quaternary circulation in the southern Indian Ocean. Mar. Micropaleontol., 4: 225-234.

Raymond, C.A. and LaBrecque, J.L., 1988. Geophysical signatures of the Agulhas Fracture Zone Ridge and Meteor Rise. In: Ciesielski, P.F., Kristoffersen, Y., et al., Proc. ODP, Init. Repts., 114: College Station, TX (Ocean Drilling Program), 27-34.

Raymond, C.A. and LaBrecque, J.L., 1991. Islas Orcadas Rise and Meteor Rise: The tectonic and depositional history of two aseismic plateaus from Sites 702, 703, and 704. In: Ciesielski, P.F., Kristoffersen, Y., et al., Proc. ODP, Sci. Results, 114: College Station, TX (Ocean Drilling Program), 5-22.

Ruddiman, W.F., Raymo, M.E., Martinson, D.G., Clement, B.M. and Backman, J., 1986. Pleistocene evolution of Northern Hemisphere climate, Paleoceanography, 4(4):353-412.

Sarmiento, J.L. and Toggweiler, R., 1984. A new model for the role of the oceans in determining atmospheric $\mathrm{pCO}_{2}$. Nature, 308:621-624.

Siegenthaler, U. and Wenk, T., 1984. Rapid atmospheric $\mathrm{CO}_{2}$ variation and ocean circulation. Nature, 308:624-626.

Sowers, T. and Bender, M., 1995. Climate records covering the last deglaciation. Science, 269: 210-214. 
Leg 177

Preliminary Report

Page 56

Shackleton, N.J. and Crowhurst, S., 1997. Sediment fluxes based on an orbitally tuned time scale 5 Ma to 14 Ma, Site 926. In Shackleton, N.J., Curry, W.B., et al., Proc. ODP, Sci. Results, 154: College Station, TX (Ocean Drilling Program), 69-82.

Tucholke, B.E. and Embley, R.W., 1984. Cenozoic regional erosion of the abyssal seafloor off South Africa. In Schlee, J.S. (Ed.), Interregional unconformities and hydrocarbon accumulation. AAPG Mem., 36:145-164.

Webb, P.-N., and Harwood, D.M., 1991. Late Cenozoic glacial history of the Ross Embayment, Antarctica. In Cronin, T.M., and Dowsett, H.J. (Eds.), Pliocene Climates. Quat. Sci. Rev., 10:215-223.

Weedon, G.P., Shackleton, N.J. and Pearson, P.N., 1997. The Oligocene time scale and cyclostratigraphy on the Ceara Rise, western equatorial Atlantic. In Shackleton, N.J., Curry, W.B., Richter, C., and Bralower, T.J. (Eds.), Proc. ODP, Sci. Results, 154: College Station, TX (Ocean Drilling Program), 101-114.

Zachos, J.C., Rea, D.K., Seto, K., Nomura, R. and Niitsuma, N., 1992. Paleogene and early Neogene deep water paleoceanography of the Indian Ocean as determined from benthic foraminifer stable carbon and oxygen isotope records. In Duncan, R.A., Rea, D.K., Kidd, R.B., von Rad, U., and Weissel, J.K. (Eds.), Synthesis of Results from Scientific Drilling in the Indian Ocean. AGU Monograph, 70: Washington, DC (American Geophysical Union), 351-387.

Zachos, James C., Flower, B. and Paul, H., 1997. Orbitally paced climate oscillations across the Oligocene/Miocene boundary. Nature, 388:567-570. 


\section{FIGURE CAPTIONS}

Figure 1. Locations of Leg 177 drill sites and previous ODP and DSDP sites in the South Atlantic relative to major frontal boundaries.

Figure 2. Leg 177 sites relative to the vertical distribution of potential temperature on a transect from the Agulhas Ridge to Bouvet Island in the southeast Atlantic Ocean. NADW = North Atlantic Deep Water; CDW = Circumpolar Deep Water; AABW = Antarctic Bottom Water; AAIW = Antarctic Intermediate Water; SASW = Subantarctic Surface Water; SAF = Subantarctic Front; and PF = Polar Front.

Figure 3. Schematic representation of present ocean circulation and interocean exchange showing the central role of the circumpolar region in global circulation (numbers are flux in Sverdrups, $1 \mathrm{sv}=106 \mathrm{~m} 3 / \mathrm{s}$ ). Not shown are the deep Indian and Pacific reservoirs (after Kier, 1988).

Figure 4. Schematic representation of the Southern Ocean showing its oceanic frontal system and sea-ice distribution relative to sites drilled by ODP and DSDP.

Figure 5. Position of Leg 177 sites relative to the gravity field of the Agulhas basin derived from Geosat ERM (Exact Repeat Mission) and GM data.

Figure 6. Schematic tectonic map of the Agulhas Basin showing Leg 177 sites relative to seafloor magnetic anomalies (after Raymond and LaBrecque, 1988). Contours are in meters

Figure 7. Tectonic reconstruction of the South Atlantic during the late Paleocene and middle Eocene with positions of sites drilled during Legs 114 and 177 (after Ciesielski, Kristoffersen, et al., 1988). 
Leg 177

Preliminary Report

Page 58

Figure 8. Temperature and salinity at water depths of Leg 177 sites taken from conductivitytemperature-depth profiles collected during site-survey cruise TN057 aboard the Thomas G. Thompson. Temperature and salinity values are shown relative to components of North Atlantic Deep Water (NADW), which includes Labrador Sea Water (LSW), Gibbs Fracture Zone Water (GFZW), and DSOW (Denmark Straits Overflow Water). Also shown are mean values for Circumpolar Deep Water (CPDW).

Figure 9. Positions of Leg 177 sites relative to the depositional regimes in the basins around South Africa (after Tucholke and Embley [1984] and Ciesielski, Kristoffersen, et al. [1988]). $1=$ core of circumbasin erosional zone; 2 = basement exposed by current erosion; $3=$ sediment wave field; $4=$ zone of thin sediment along the mid-oceanic ridge axis and beneath the ACC; $5=$ thick sediment drifts with weak acoustic laminae; $6=$ generalized bathymetric contours as labeled (4500 $\mathrm{m}$ is a dashed line); $7=$ limit of thick, moderately laminated drifts of diatomaceous sediment extending north of the polar front; $8=$ glide plane scars at the head of slumps and slides; 9 = approximate seaward limit of slumps and slides; $10=$ seamounts; $11=$ piston cores of pre-Quaternary outcrops (from left to right, top to bottom: Pliocene, Miocene, Oligocene, Eocene, Paleocene, and Cretaceous); 12 = manganese nodules/pavement observed in bottom photographs; 13 = current direction from bottom photographs; $14=$ direct current measurements; and $15=$ flow of AABW inferred from bottom-water potential temperature.

Figure 10. Downhole variations of percent blue reflectance (450-550 nm), volume-specific magnetic susceptibility, gamma-ray attenuation (GRA; line, smoothed data) and moisture and density (MAD; white dots) bulk density, and natural gamma radiation at Site 1094. Dashed lines indicate marine isotope stages inferred from peaks in blue reflectance which represent carbonate peaks.

Figure 11. Summary of lithologies and paleomagnetic stratigraphies of expanded sections recovered at Sites $1089\left(41^{\circ} \mathrm{S}\right), 1091\left(47^{\circ} \mathrm{S}\right), 1093\left(50^{\circ} \mathrm{S}\right)$ and $1094\left(53^{\circ} \mathrm{S}\right)$ along a north-south transect across the ACC; w.d. = water depth. The geomagnetic polarity time scale of Cande and Kent (1992) is shown on the right. 
Figure 12. Age-depth plots for Leg 177 sites for the Pliocene-Pleistocene.

Figure 13. Age-depth plots for Leg 177 Sites 1088,1090 , and 1092 for the middle
Eocene-Pleistocene. At Site 1088, the length of the dashed lines indicating hiatuses are not
representative of the length of time involved. To make them visible on the figure, the dashed
lines were extended across the depth/time line.

Figure 14. Summary of lithologies for Leg 177 Sites 1088 through 1094; w.d. = water depth.

Figure 15. Example of a laminated diatom mat from interval 177-1093A-23H-4, 78-108.5 cm.

Figure 16. Correlation of \%red reflectance $(650-750 \mathrm{~nm})$ during the Brunhes Chron in expanded sections from Sites $1089\left(41^{\circ} \mathrm{S}\right), 1091\left(47^{\circ} \mathrm{S}\right), 1093\left(50^{\circ} \mathrm{S}\right)$, and $1094\left(53^{\circ} \mathrm{S}\right)$ along a north-south transect across the ACC. Dashed lines indicate marine isotope stages inferred from peaks in blue reflectance which represent carbonate peaks. $\mathrm{B} / \mathrm{M}=$ Brunhes/Matuyama boundary.

Figure 17. Percent blue and red reflectance at Site 1090.

Figure 18. Pore-water profiles of chloride, sulfate, phosphate, and manganese from the high-
sedimentation-rate diatomaceous-ooze Sites 1091, 1093, and 1094. See text and individual site
chapters for a more detailed explanation of the profiles.

Figure 19. Variation in oxygen-isotope ratio of deep-sea benthic foraminifers from the Atlantic Ocean (left) relative to the global sea-level curve inferred from seismic stratigraphic analysis (middle) (after Barrett, 1994). Shown on the right are Leg 177 sequences recovered over these time intervals. 


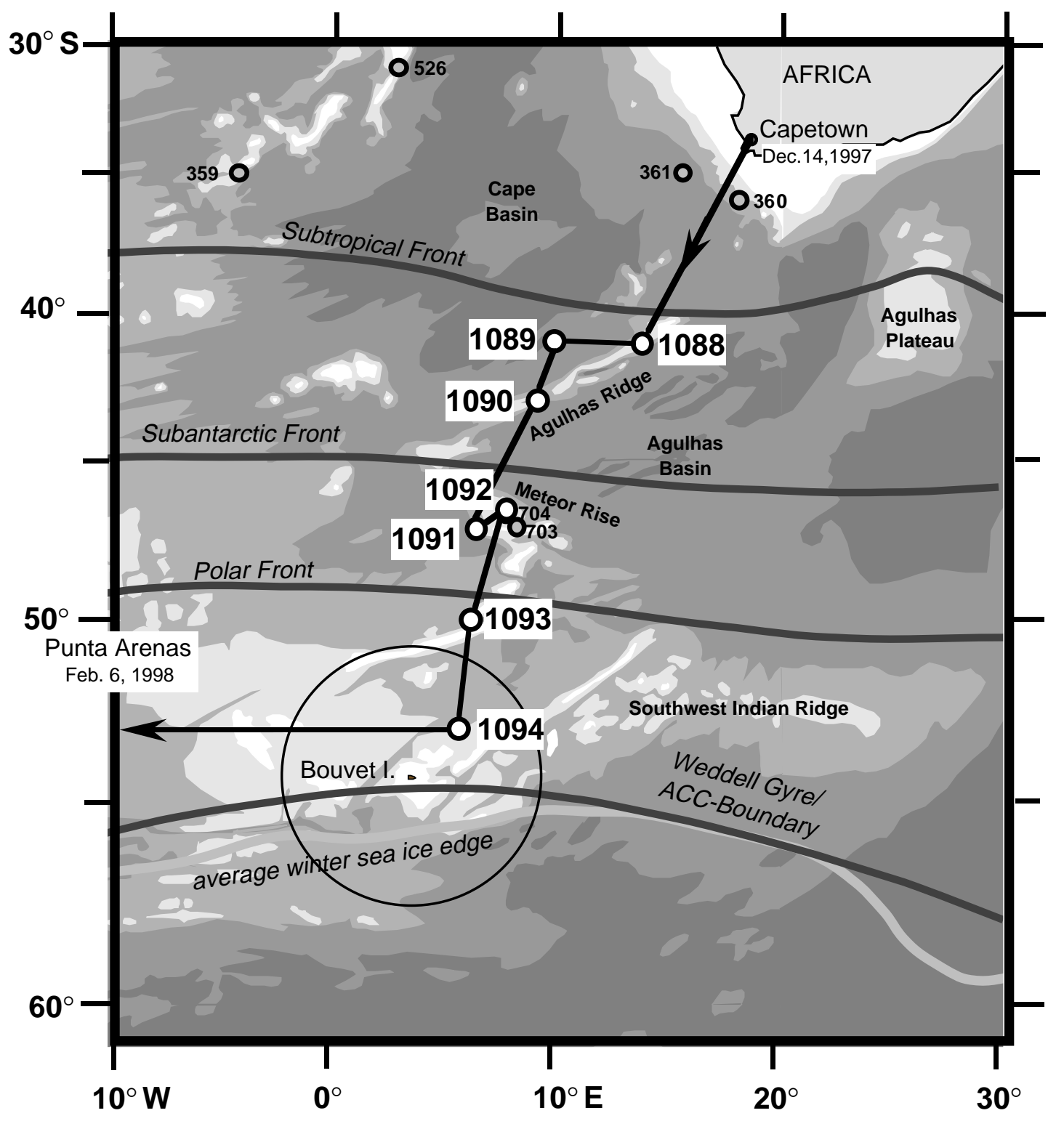

Figure 1 



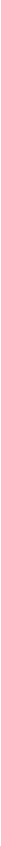

Figure 3 



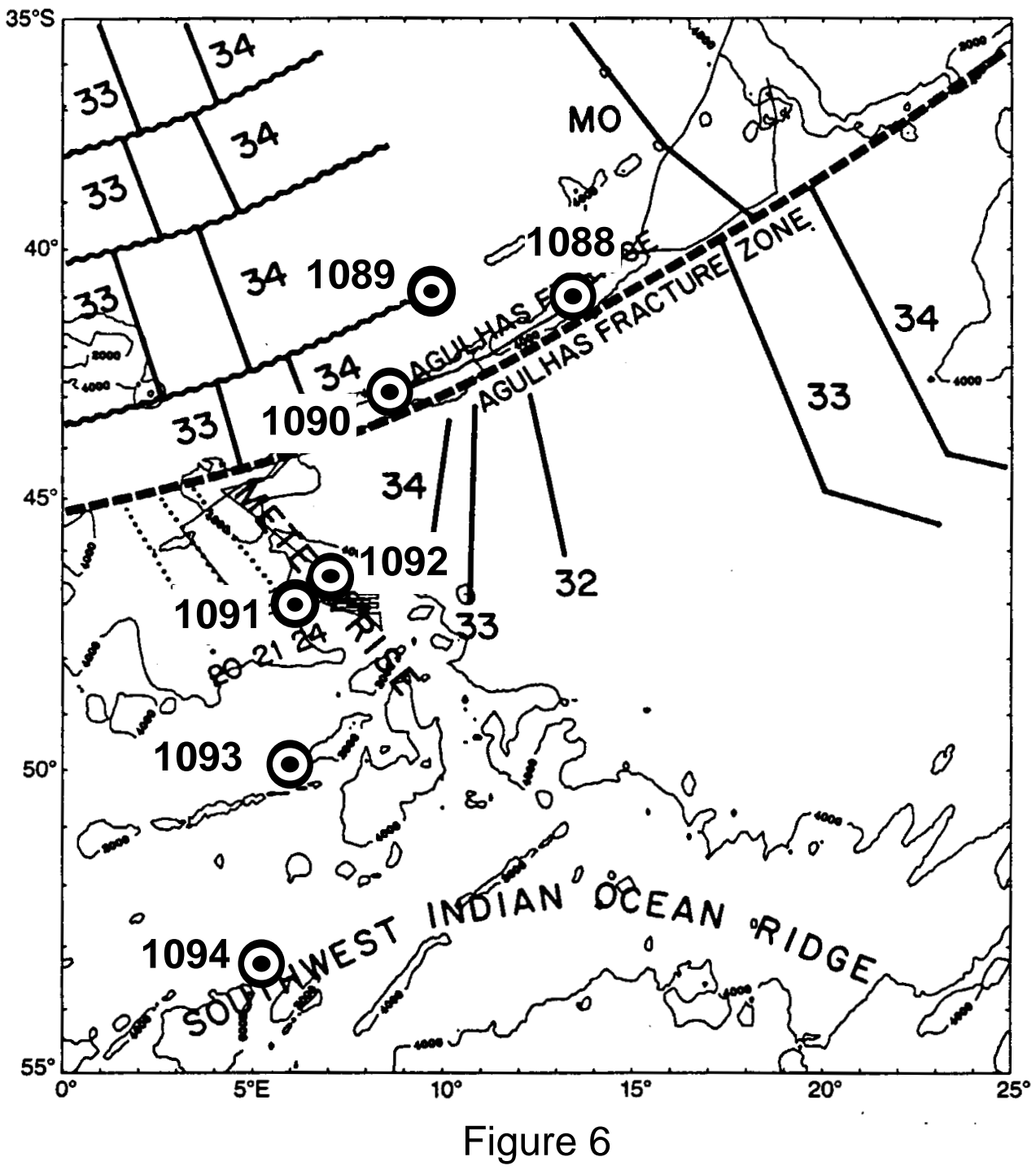




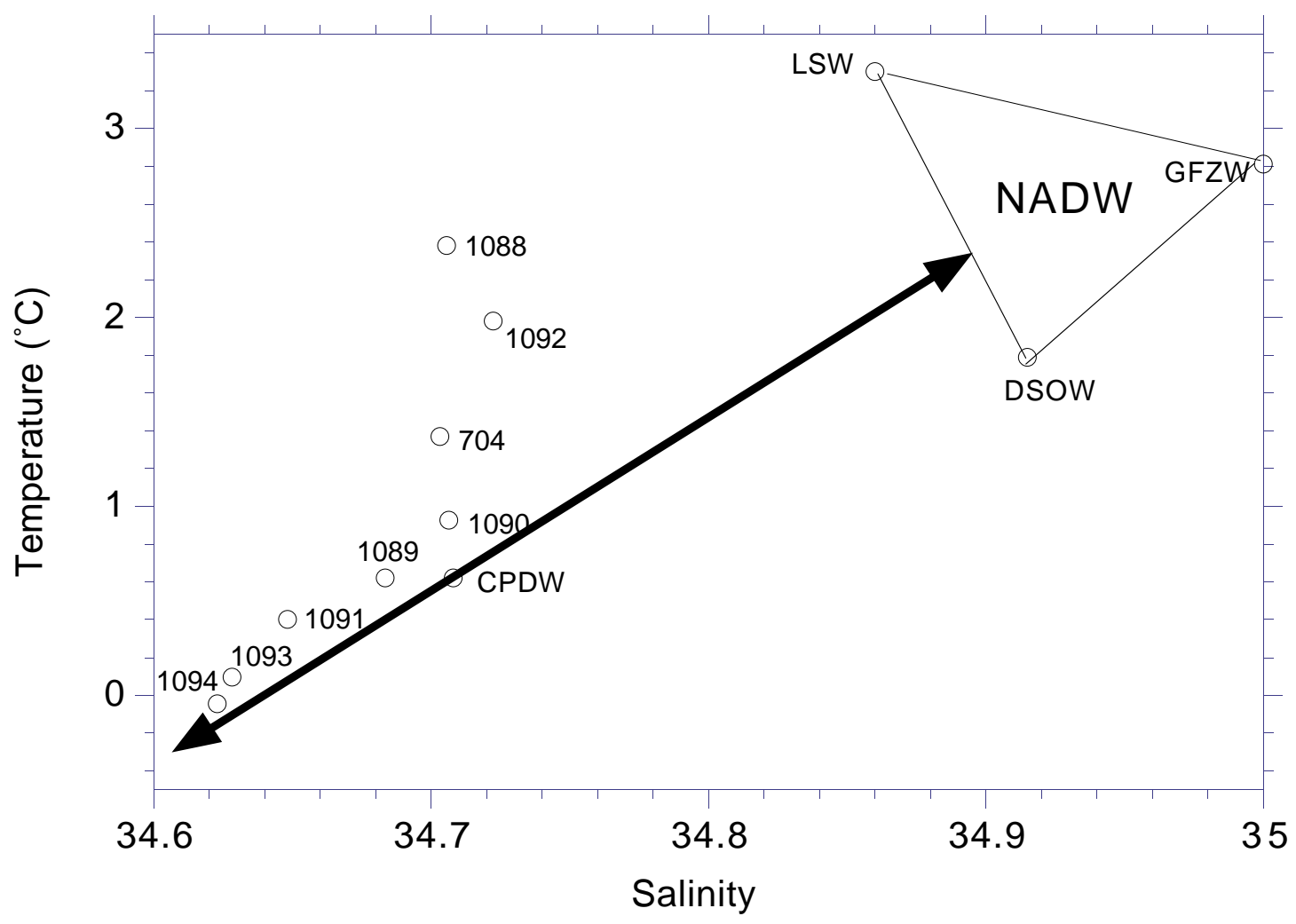

Figure 8 
$\%$ Reflectance

(blue; 450-550 nm)

Magn. susceptibility

GRA bulk density

$\left(10^{-5} \mathrm{SI}\right)$
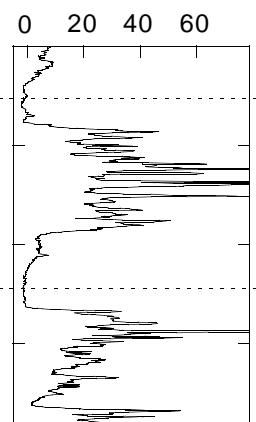

$\widehat{\partial}$
है
竞
0

100

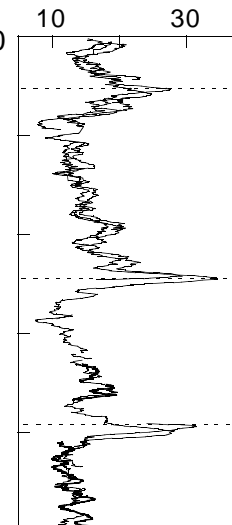

50

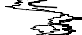

है
$1.1 \quad 1.3 \quad 1.4$

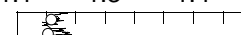

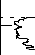

ह.

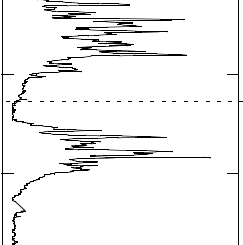

2
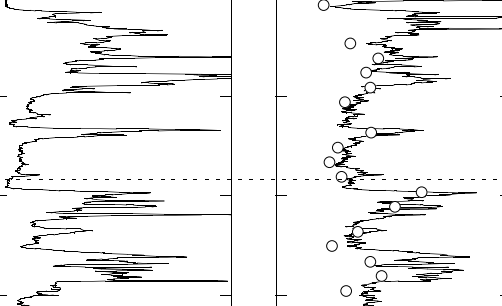

Natural gamma (cps)

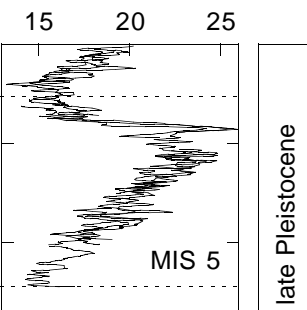

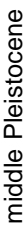
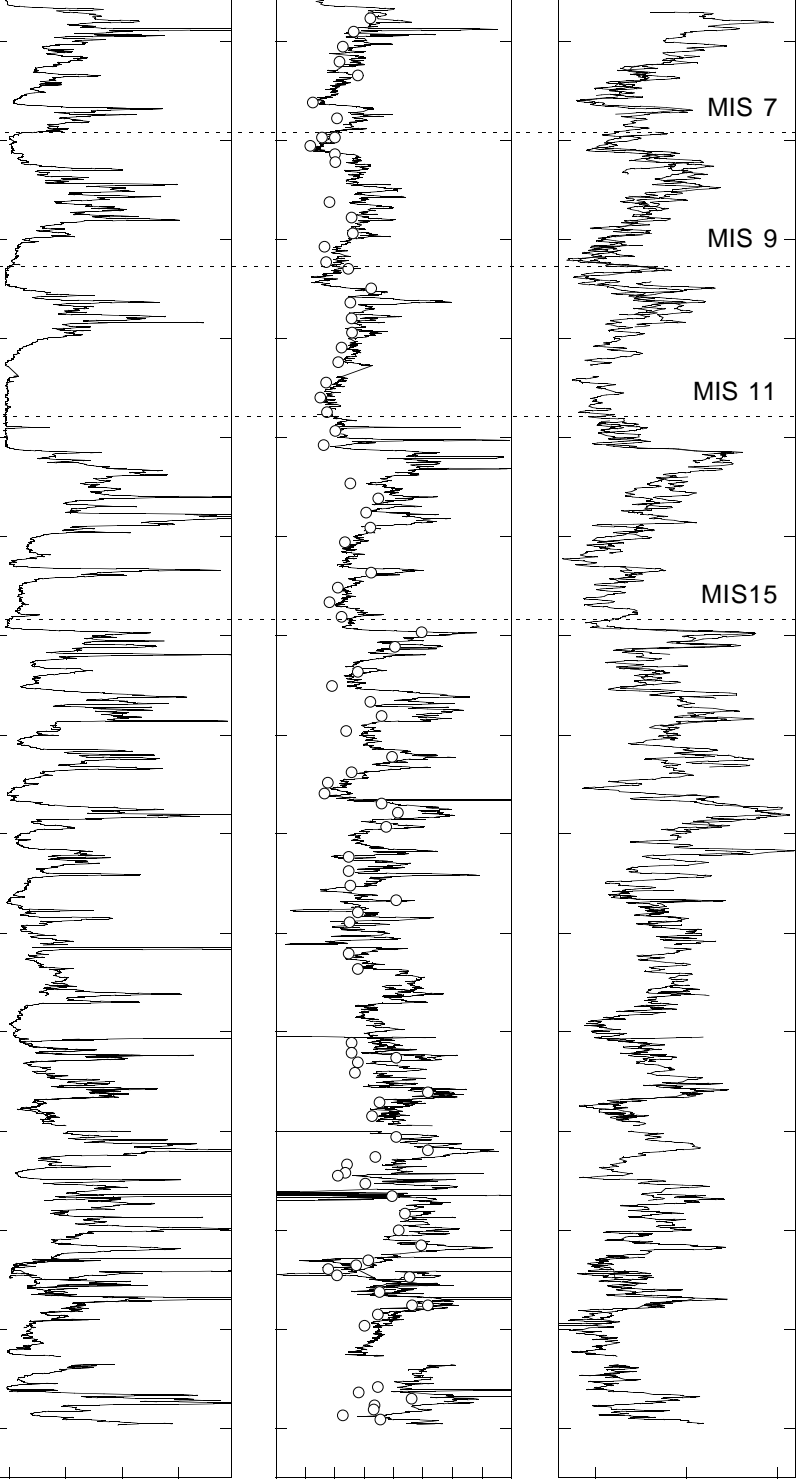

MAD bulk density $\left(\mathrm{g} / \mathrm{cm}^{3}\right)$ 


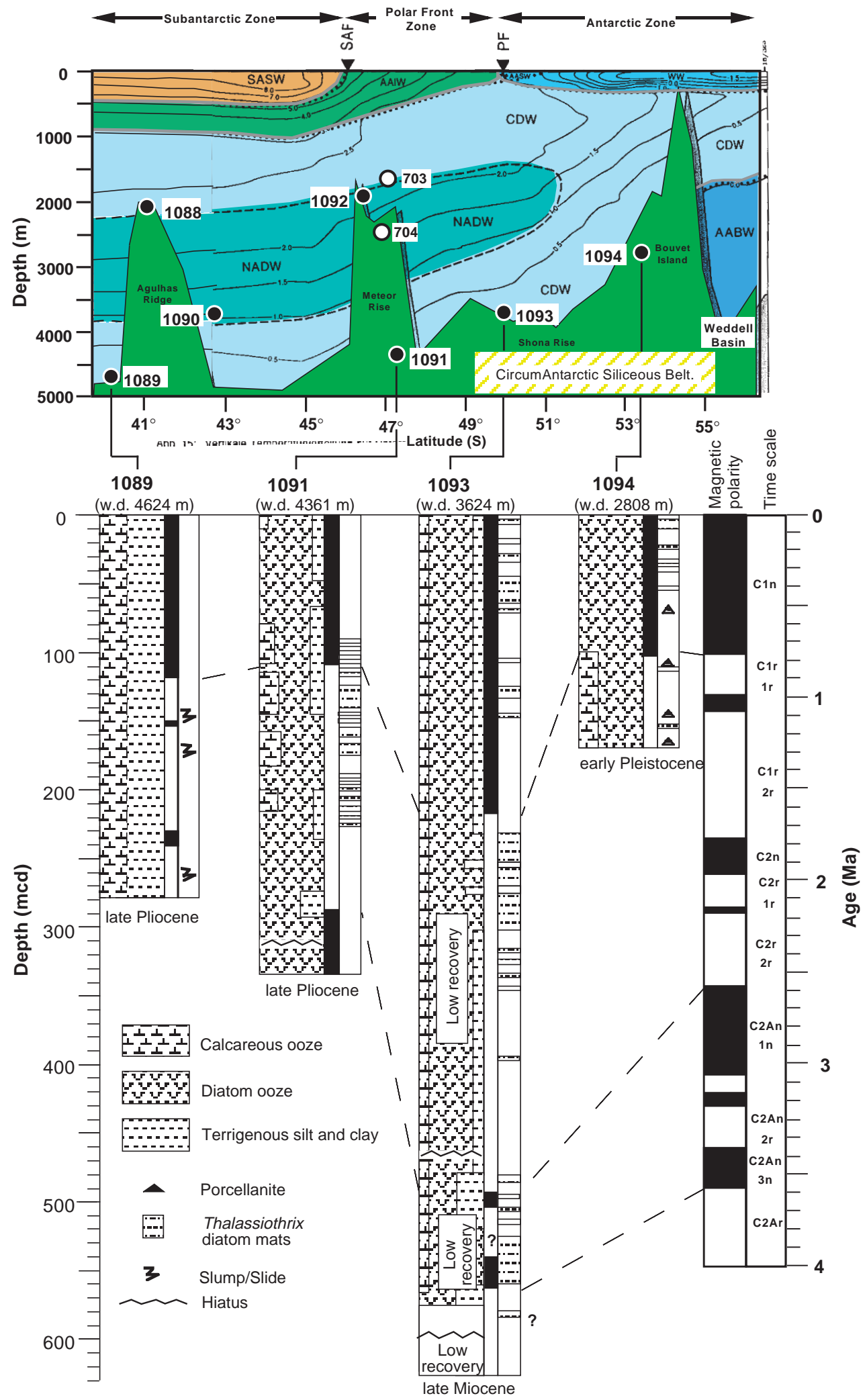

Figure 11 


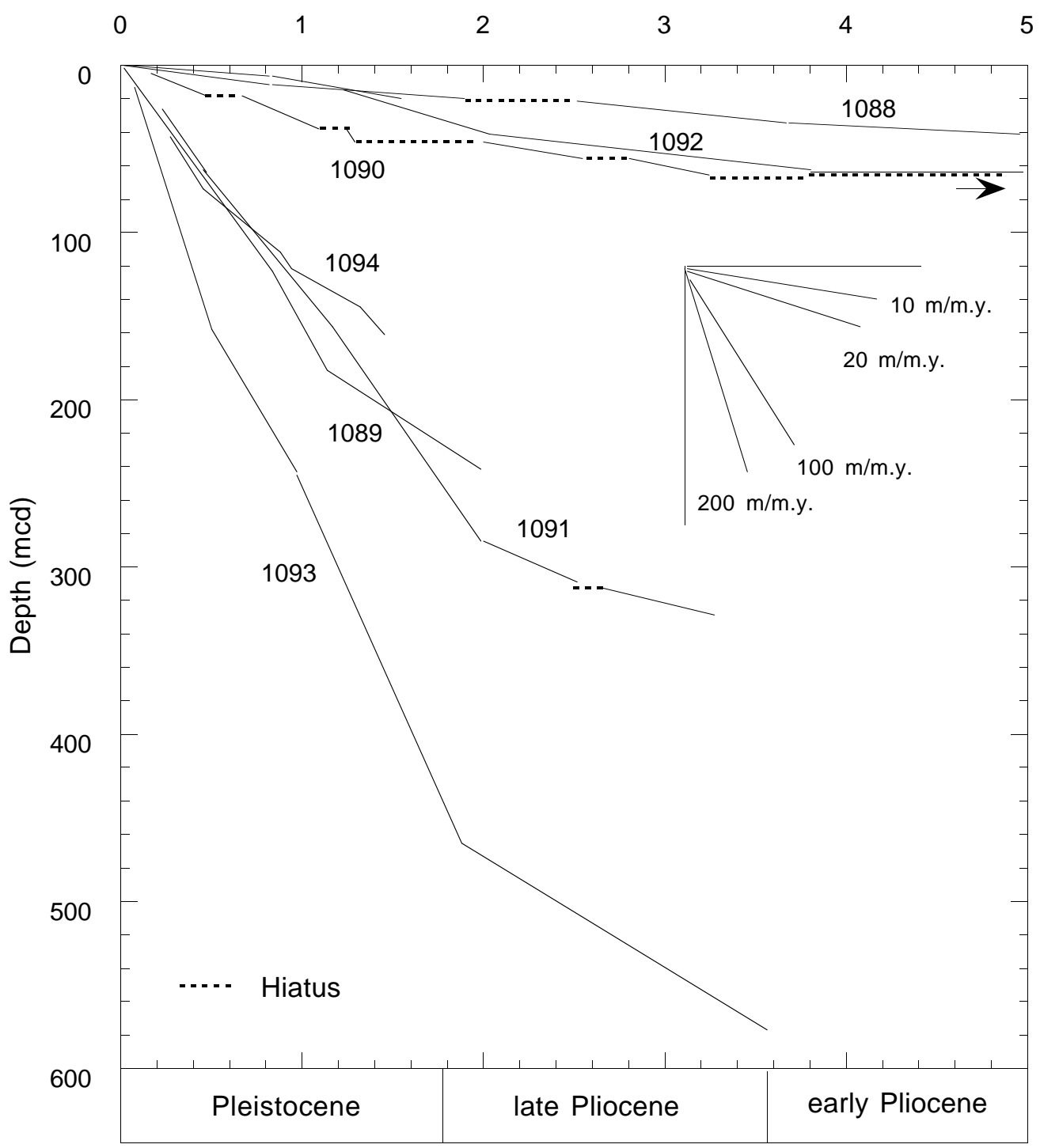

Figure 12 
Age (Ma)

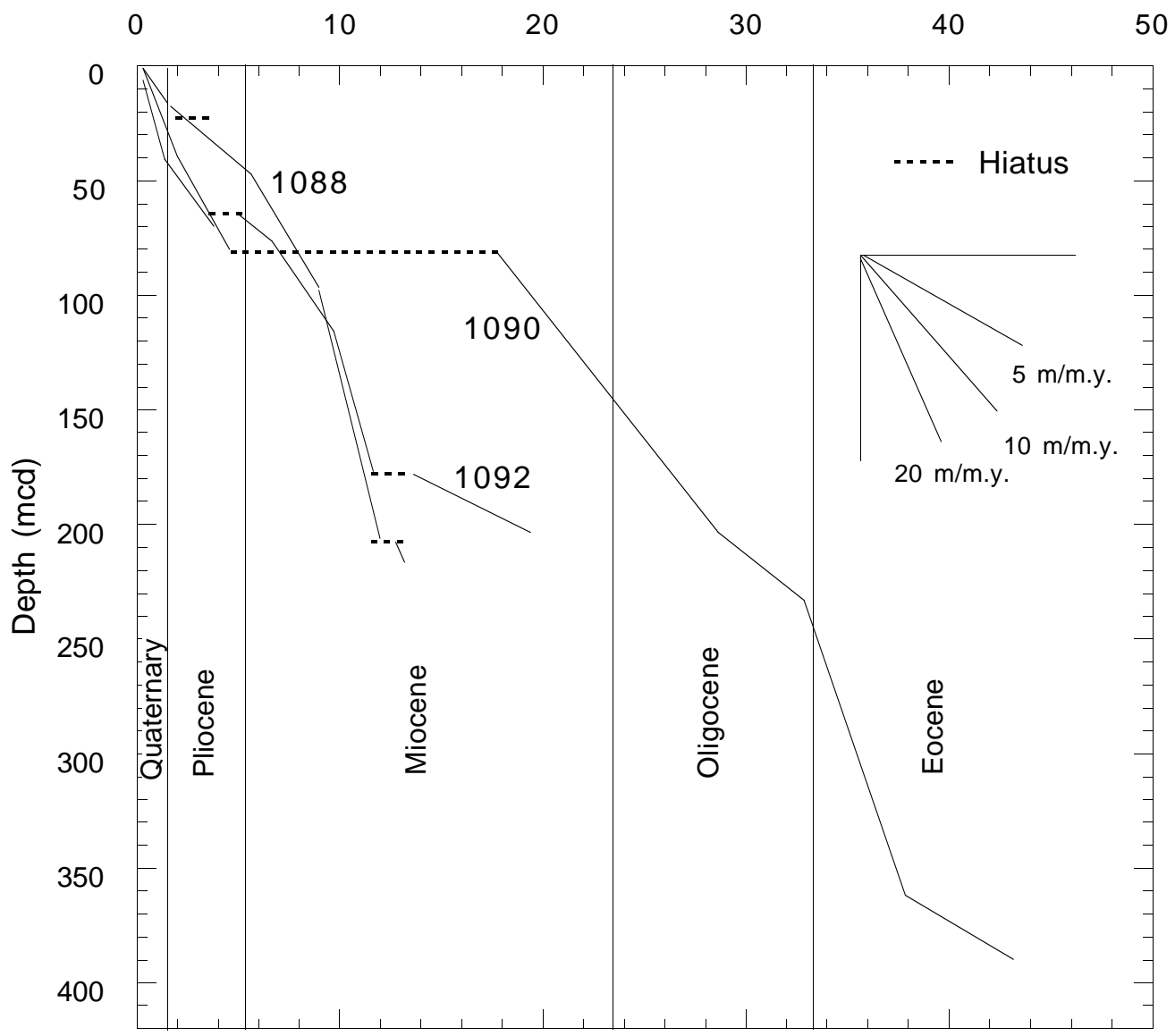

Figure 13 



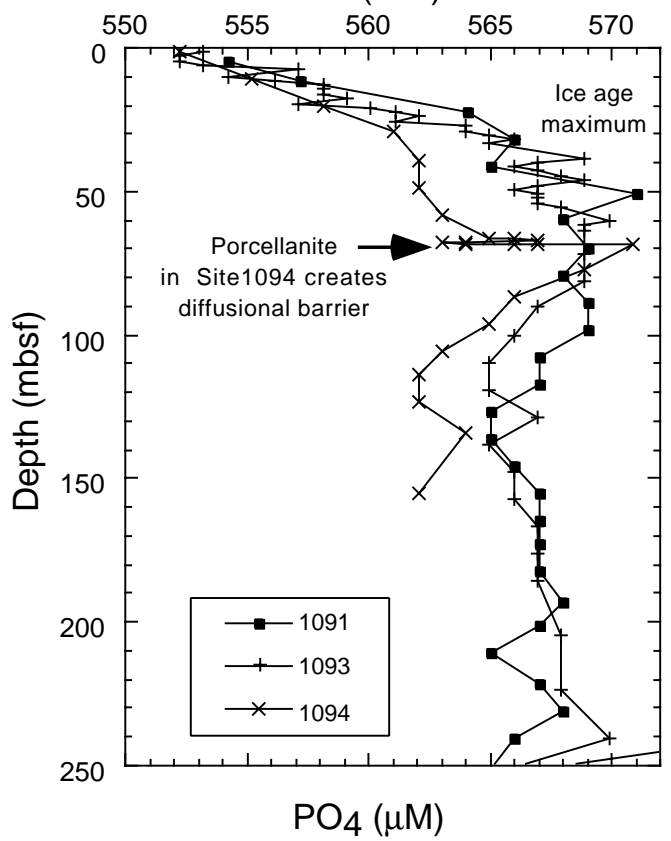

$\mathrm{SO}_{4}(\mathrm{mM})$
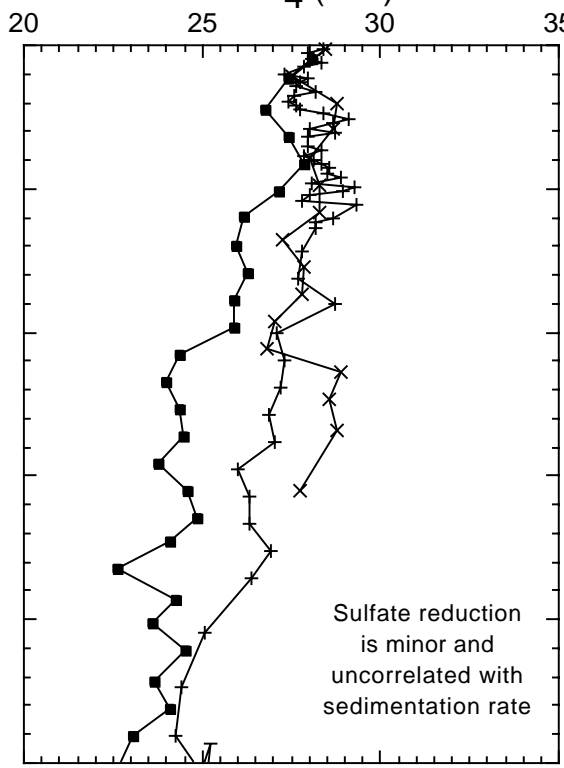

\section{$\mathrm{Mn}(\mu \mathrm{M})$}
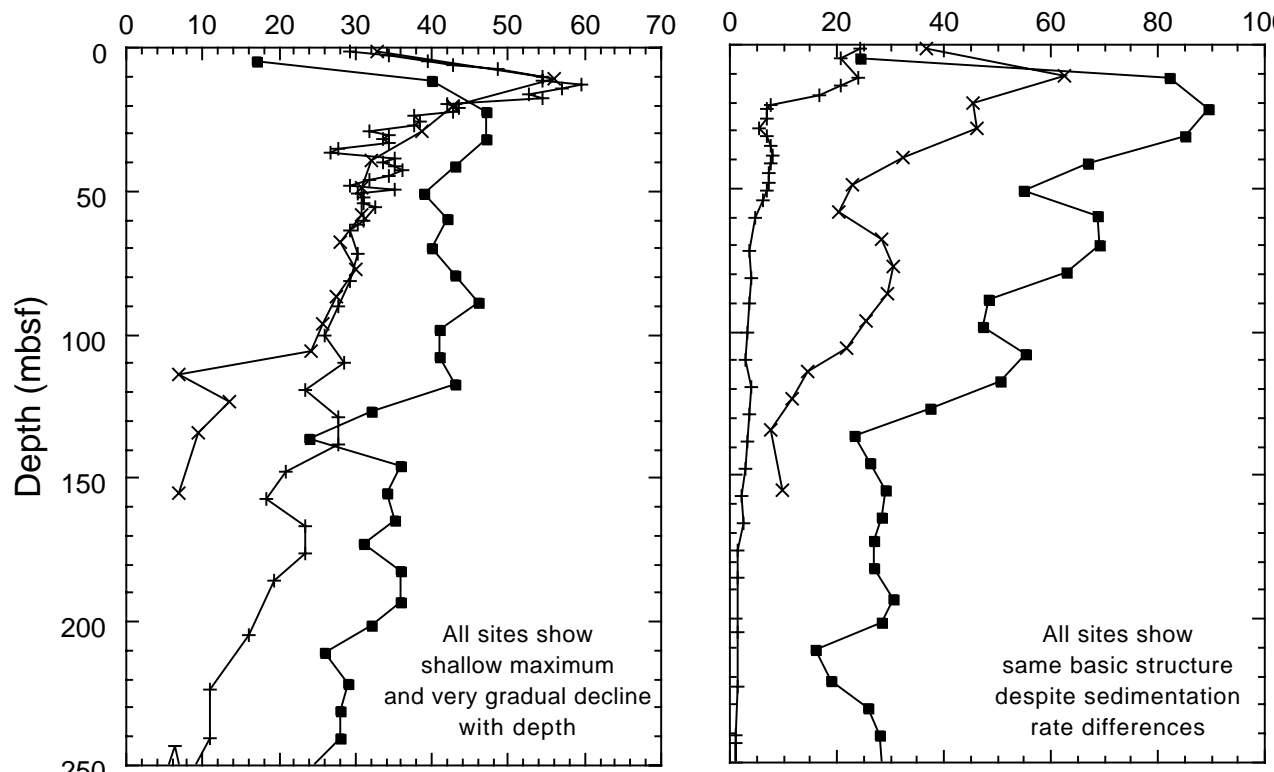

Figure 18 


\section{Oxygen isotope and sea level records}

Sites

OXYGEN ISOTOPES

\section{LOW}

HIGH

SEA LEVEL / TEMPERATURE

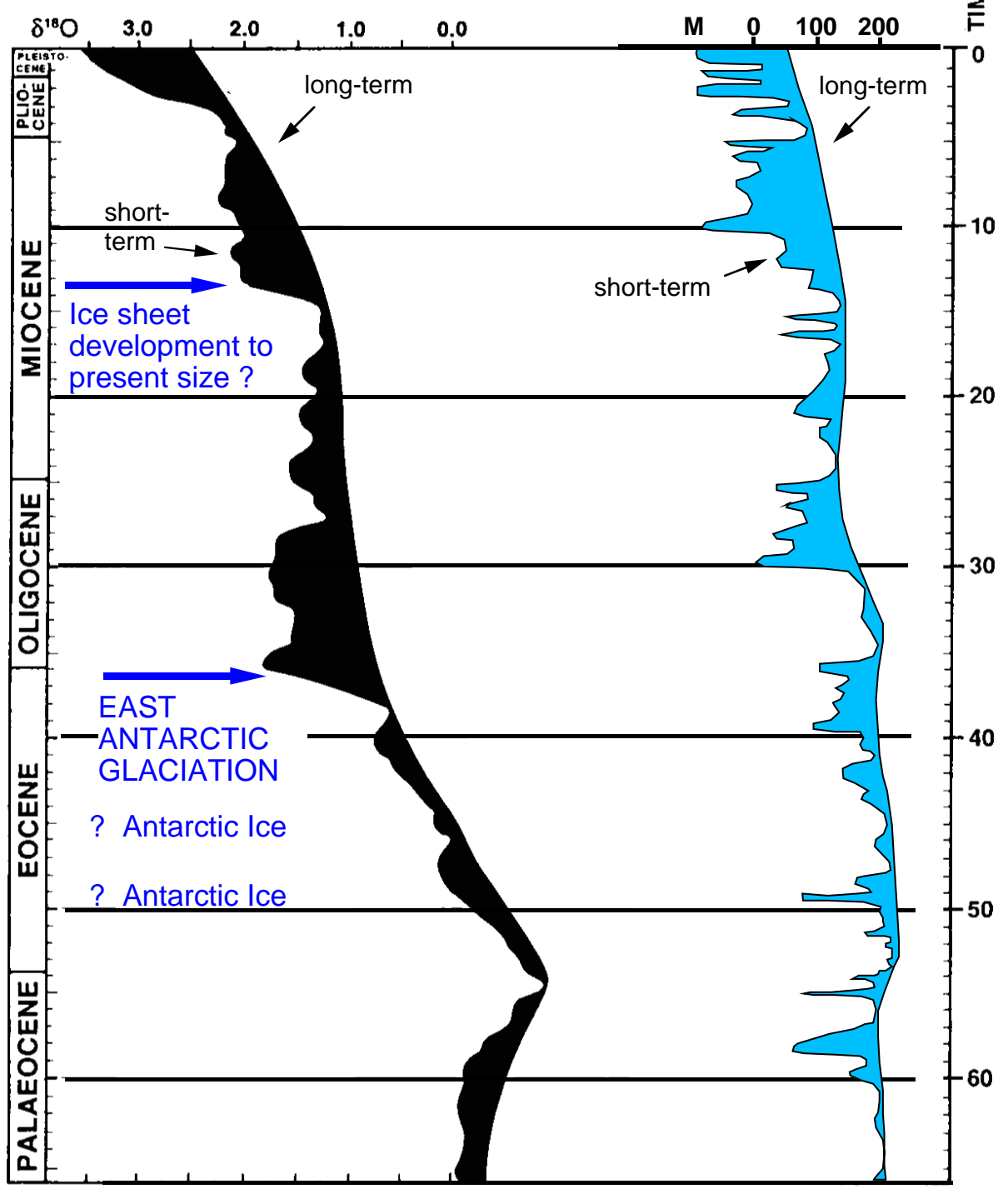

SEQUENCE ANALYSIS خ

LOW HIGH $z$

108810901092

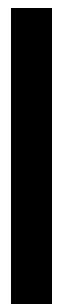

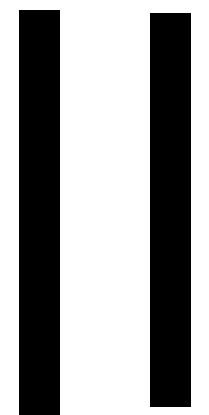

$1 \% \circ \delta^{18} \mathrm{O}=110 \mathrm{~m}$ sea level or $4^{\circ} \mathrm{C}$ water temperature change (modified from Barrett, 1994) 
OPERATIONS SYNOPSIS 
Leg 177

Preliminary Report

Page 80

The operations and engineering personnel aboard the JOIDES Resolution for Leg 175 were

Operations Manager

Schlumberger Engineer
Glenn Foss

Steven Kittredge

\section{TRANSIT FROM CAPE TOWN TO SITE 1088}

Leg 177 began at $1130 \mathrm{hr}$ on 9 December 1997 with the port call in Cape Town. The traditional joint ODP/ODL annual holiday celebration was held at the Capetonian Hotel the evening of 10 December. This year's festivities were combined with a retirement party for Captain Ed Oonk.

Replacement and repair work on communications, thruster, waste management, power generation, and lifeboat systems extended the port call to five full days. At $1315 \mathrm{hr}$ on 14 December 1997, the port call ended with the last line ashore, and the vessel headed for Site 1088 (proposed Site TSO-2B), which is located about $444 \mathrm{nmi}$ southwest of Cape Town. Because of relatively heavy weather, plans to approach the site along a reference seismic profile were abandoned and the approach was made directly based on Global Positioning System (GPS) coordinates. The transit was accomplished in $56.5 \mathrm{hr}$ at an average speed of $8.9 \mathrm{kt}$.

\section{SITE 1088}

(Proposed Site TSO-2B)

\section{Hole 1088A}

A positioning beacon was launched at $2145 \mathrm{hr}$ on 16 December, beginning site operations for the leg. The advanced piston corer (APC) coring assembly was deployed and, prior to spud-in, a temperature measurement was taken a few meters above the seafloor with the APC temperature tool (APCT) in the APC core-catcher shoe. Hole 1088A was spudded with the first APC coring attempt at $0930 \mathrm{hr}$ on 17 December. An anomalous pressure bleedoff indication was noted when the corer was actuated, and the core barrel was recovered full of disturbed sediment. These were 
indications that the bit had been positioned too deep for the spud attempt and/or that the shearpins had failed prior to the corer reaching the seafloor.

\section{Hole 1088B}

The APC was redressed and the drill string was raised $5 \mathrm{~m}$ for a second, successful spud-in. A 5.5-m core was recovered, establishing the seafloor depth at 2092 meters below rig floor (mbrf). APC coring continued with azimuthal orientation beginning with Core $4 \mathrm{H}$ and APCT measurements taken every third core. APCT data were adversely affected by vessel heave even though weather conditions had improved somewhat.

After Core 14H at 129 meters below seafloor (mbsf), the coring line parted at the ropesocket. It was necessary to fish the sinker bars and coring assembly with a second core barrel fitted with a hard-formation core catcher.

As the corer was being lowered for Core $15 \mathrm{H}$, a ground fault was detected in the top drive. The corer was recovered, and the bit was pulled above the seafloor for the protection of the drill string while troubleshooting was in progress. The electrical problem turned out to be limited to a nick in the insulation of one of the top drive's umbilical cables. Temporary repairs were made to the insulation, and operations resumed after $3 \mathrm{hr}$ of repair time.

\section{Hole 1088C}

Hole 1088C was spudded without the position being offset from Hole 1088B. A seafloor depth of $2093.7 \mathrm{mbrf}$ was indicated by the recovered core. The hole was drilled without coring to 124 mbsf, where continuous coring resumed. After four additional APC cores to $162 \mathrm{mbsf}$, APC coring was abandoned due to excessive overpull and the requirement to drill around the core barrel to free it. Rotary coring then continued with the extended core barrel (XCB) system to 233 mbsf (Core 13X). At that point, coring operations were terminated at the request of the scientific investigators, well short of the originally projected penetration of about $700 \mathrm{~m}$. The drill string was recovered, the positioning beacon was released and retrieved, and the vessel departed at $2230 \mathrm{hr}$ on 18 December. 
Leg 177

Preliminary Report

Page 82

\section{SITE 1089 \\ (Proposed Site SubSAT-1B)}

Light winds and calm seas prevailed during the westward transit to Site 1089 . The 166-nmi transit was made in $17.5 \mathrm{hr}$ at an average speed of $9.5 \mathrm{kt}$. The vessel arrived at the Southern Cape Basin site on 19 December, and a positioning beacon was launched at $1615 \mathrm{hr}$.

\section{Hole 1089A}

The bit was run to $4628 \mathrm{~m}$, and the APC coring assembly, fitted with an APCT temperature shoe, was deployed. After a bottom-water temperature measurement had been taken a few meters above the seafloor, Hole 1089A was spudded at $0450 \mathrm{hr}$ on 20 December with a core that recovered $7.3 \mathrm{~m}$ of sediment and fixed the seafloor depth at $4630.2 \mathrm{mbrf}$. Core orientation began with Core $4 \mathrm{H}$.

Operations at Hole 1089A were plagued by numerous problems. Cores $3 \mathrm{H}, 4 \mathrm{H}$, and $6 \mathrm{H}$ suffered core liner failures, with reduced recovery and disturbed core. The attempted APCT measurement with Core $4 \mathrm{H}$ was unsuccessful due to heave motion. Another downhole temperature was attempted with Core $7 \mathrm{H}$. After a 10-min equilibration period, the overshot shearpin beneath the Tensor pressure case had failed, so a second run was required to retrieve the APC assembly. The APC was engaged successfully, but the coring line parted above the sinker bars. The remaining wire was reeled onto the winch, and the broken end was found about $125 \mathrm{~m}$ short of the ropesocket. A wireline fishing operation retrieved the broken wire and sinker bar assembly, and a pipe trip was avoided. It was discovered that the overshot shearpin had failed when the line parted and the APC was dropped, so it then became necessary to make a third wireline run to retrieve the APC.

Because of the two coring line failures in quick succession, the new forward wire was put into service. The aft wire was relegated to backup status. 
Leg 177

Preliminary Report

Page 83

When Core 7H arrived on deck, it was found to have a completely collapsed liner, and the APCT record was again degraded by vessel motion. APCT runs were discontinued at that point. Coring proceeded with liner failures of varying severity on nearly every core. About every other core had dismal recovery. Vessel heave, as noted by the driller, reached $12 \mathrm{ft}$ at times. Coring conditions improved on the morning of 21 December. Core liner failures persisted, but generally were not catastrophic and had less of a disruptive effect on the stiffer sediment.

Hole 1089A was terminated at a total depth (TD) of $216.3 \mathrm{mbsf}$, short of APC refusal, after Core $23 \mathrm{H}$. The decision to abandon was primarily made to take advantage of good weather conditions for coring the upper sediment section in Hole 1089B. The drill string was pulled above the seafloor at $1315 \mathrm{hr}$ on 21 December to begin operations at Hole 1089B.

\section{Hole 1089B}

A stratigraphic overlap was desired, so the initial APC core interval was positioned $3.5 \mathrm{~m}$ higher than the equivalent interval of Core 1089A-1H. The spud attempt yielded no sediment and a broken core liner. Two additional "mudline" cores were attempted from $1 \mathrm{~m}$ deeper than the first attempt. In both cases the core liners broke near the top and the core catchers contained plastic liner fragments and only traces of sediment. On the fourth spud attempt the bit was lowered to $4630 \mathrm{mbrf}$ in an effort to recover more consolidated sediment that would not be so easily washed from the core barrel while still maintaining an overlapping depth section. That attempt yielded a core with $4.8 \mathrm{~m}$ of sediment (and a broken liner). On the basis of recovery, seafloor depth was set at $4634.7 \mathrm{mbrf}$, but there is a strong possibility that some core was lost, which would make the seafloor depth too deep.

Coring success improved greatly on 22 December. Every effort was made to minimize core liner failures by adopting measures to reduce shock and stress on the brittle liners. Those included elimination of APCT runs and core orientation, trimming down APC piston seals, closing more APC speed ports, etc. It is not clear, though, whether these measures were responsible for the dramatic improvements, given the circumstances of similar coring problems later in the cruise. Some liner failures persisted, but they had a minor effect on core recovery and 
Leg 177

Preliminary Report

Page 84

quality. Continuous APC cores were taken to a depth of $265 \mathrm{mbsf}$. The final two cores, $28 \mathrm{H}$ and $29 \mathrm{H}$, exhibited incomplete stroke and recovery and about 40 kips overpull. A final core attempt resulted in a misrun when the APC apparently didn't land and seal properly at the outer core barrel. Hole 1089B then was terminated because the scientific objectives had been achieved.

\section{Hole 1089C}

Excellent weather and minimal vessel heave conditions continued as a partial seafloor core was attempted with the core bit at $4625 \mathrm{mbrf}$. The first core recovered $2.4 \mathrm{~m}$ of sediment, setting the seafloor depth at $4632.1 \mathrm{mbrf}$. Core $2 \mathrm{H}$ was started $2 \mathrm{~m}$ below the bottom of Core $1 \mathrm{H}$ to provide stratigraphic overlap. Continuous coring then proceeded, with orientation beginning on Core $4 \mathrm{H}$. Good recovery was achieved, but core liner failures were experienced on about $50 \%$ of the cores. Most of the failures were small implosions near the top of the liner that had little effect on the core.

Weather conditions deteriorated through the day with wind gusts up to $32 \mathrm{kt}$, rain showers, and a near reversal of wind direction in the afternoon. Two sets of 3-m swells arrived at nearly right angles. As a result, the vessel could not take a heading to minimize roll and heave. Rig operating limits were approached, with rolls of $9^{\circ}$ and heaves of up to $14 \mathrm{ft}$. During the period of increasing vessel motion, double wireline trips were required for Cores $11 \mathrm{H}$ (did not actuate) and $13 \mathrm{H}$ (sheared overshot pin and mechanical actuation). Conditions improved dramatically in the late evening as the wind shifted and dropped to a light breeze. One set of swells died rapidly, and operating conditions improved just as quickly. Coring was halted at $194.4 \mathrm{mbsf}$ when scientific objectives were reached.

\section{Hole 1089D}

A mudline core fixed the seafloor depth at 4628.5 mbrf and continuous APC cores were taken to a TD at 118 mbsf. Again orientation began with Core 4H. Excellent core recovery and sediment conditions were achieved under good operating conditions. Only two minor core liner failures occurred in the 13 cores recovered. 
The fourth penetration at Site 1089 completed stratigraphic coverage, filling all recovery gaps in the upper portion of the section. With the scientific coring objectives for the site attained, coring ceased at $1900 \mathrm{hr}$ on Christmas Eve. The drill string was tripped, and the vessel got under way at $0530 \mathrm{hr}$ on 25 December.

\section{SITE 1090}

(Proposed Site TSO-3C)

The 127-nmi transit to Site 1090 on the south flank of the Agulhas Ridge began in fair weather with a light northerly breeze that strengthened as the vessel approached the new drill site. The average transit speed, therefore, was $11.0 \mathrm{kt}$. By the time the ship turned and maneuvered onto the site, however, the wind had reached gale force and large seas were building. A positioning beacon was dropped on 25 December at $1715 \mathrm{hr}$ and the pipe trip began as soon as stable positioning had been achieved.

\section{Hole 1090A}

The winds continued to strengthen over the next few hours, with gusts reaching $50 \mathrm{kt}$ and a large swell developing. At $2300 \mathrm{hr}$ the pipe trip was stopped (with $3305 \mathrm{~m}$ suspended) as a result of violent pitch and heave motion that posed a hazard to personnel and the drill string. At midnight, the wind shifted from northerly to westerly but did not diminish in velocity. That caused both positioning and motion problems for the ship, with large swells at high angles to strong winds and seas. There was insufficient power to maintain station while on a minimum-roll heading, and the vessel was blown about 1.1-nmi off station to the east-northeast. Wind velocity and the northerly swell decreased slowly through the morning, and operations resumed after a weather delay of $13.25 \mathrm{hr}$. The pipe trip was completed in still marginal conditions, and the top drive and APC coring assembly were deployed.

Hole 1090A was spudded with an APC core shot from 3707 mbrf at $1515 \mathrm{hr}$ on 26 December. Pump pressure indicated a mechanical shear, casting considerable doubt on the quality of the 
Leg 177

Preliminary Report

Page 86

mudline core. The core barrel contained $7.0 \mathrm{~m}$ of sediment, indicating a seafloor depth of 3709.5 mbrf. Because of the amount of scientific interest in the interface core and because of its probable poor quality, a second seafloor core was requested.

\section{Hole 1090B}

The second spud attempt was positioned $2 \mathrm{~m}$ higher than for Core 1090A-1H. Core 1090B-1H gave the same pressure indication, however, and recovered $4.2 \mathrm{~m}$ of sediment. Because of the operating conditions, no attempt was made to obtain core orientation or temperature data from Hole 1090B. APC coring continued to $185 \mathrm{mbsf}$, where the coring mode was switched to XCB due to the stiff, chalky nature of the sediment and the increasing frequency and severity of liner failures.

Excellent XCB core recovery was achieved in slowly improving weather and motion conditions. At 295 mbsf, hard drilling was encountered, and it was necessary to pull a short core and to install a hard-formation coring shoe. The thin, hard stratum was penetrated successfully by Core $33 \mathrm{H}$, but the hard material was not recovered, probably because of a total core liner failure that limited recovery to less than $3 \mathrm{~m}$. Subsequent cores recovered isolated thin layers of Eocene porcellanite. Core $42 \mathrm{X}$ reached the coring target depth at $397.5 \mathrm{mbsf}$, and the bit was then pulled back above the seafloor to end operations in Hole 1090B.

\section{Hole 1090C}

The initial core interval was positioned $3 \mathrm{~m}$ deeper (per drill string measurement) than that of Hole 1090B. After the rig had been offset $10 \mathrm{~m}$ laterally, the first core recovered an unexpectedly short $2.8 \mathrm{~m}$ of sediment, setting the seafloor depth at 3714.7 mbrf by convention. Seven additional APC cores were taken to a depth of $69.3 \mathrm{mbsf}$ to cover the interval of primary interest. Given the unfavorable weather prognosis at that time, it was decided to pull out and start a new hole in the critical upper section before the conditions could deteriorate. 
Leg 177

Preliminary Report

Page 87

\section{Hole 1090D}

The vessel was offset an additional $10 \mathrm{~m}$ in the direction of the positioning beacon. Again the core interval was adjusted $3 \mathrm{~m}$ deeper, and again a less-than-full core was recovered. The new seafloor depth was calculated to be 3713.1 mbrf. Continuous APC cores were taken to refusal, with orientation beginning with Core $4 \mathrm{H}$. Significant overpull of about 45 kips was noted on the third core beyond the point where XCB coring had began in Hole 1090B. The next core, 24H, could not be freed with 100 kips overpull, and it was necessary to "drill over" with the main bit to free the APC barrel. Heave conditions allowed only about $6 \mathrm{~m}$ of drillover. Even then, 100 kips were required to free the core barrel, and APC refusal was acknowledged. Repeating the XCB-cored section from Hole 1090B was of secondary priority, and coring was terminated in Hole 1090D at 225.9 mbsf so that another APC section could be drilled.

\section{Hole 1090E}

Operational conditions and the available time allowed for a third hole to be drilled to the depth of APC refusal to provide complete stratigraphic coverage for that interval. The rig was offset back to the positioning coordinates of Hole 1090C, and the bit was positioned at $3714.5 \mathrm{mbrf}$ for the initial core. The core recovered $8.7 \mathrm{~m}$ of sediment, placing the seafloor depth at $3715.3 \mathrm{mbrf}$ by convention. Hole-to-hole correlation later indicated that the top of the core was taken from about $2 \mathrm{~m}$ below the seafloor (as planned) and that seafloor depth was near $3713 \mathrm{mbrf}$. Again, continuous APC cores were taken to refusal, with orientation beginning with Core $4 \mathrm{H}$. Weather and vessel-motion conditions began to deteriorate as operations began on Hole 1090E, and the effect on coring results was evident as core recovery was somewhat reduced in the upper portion of the section. Conditions moderated as operations progressed, but high heave continued to be a factor. Winds increased to more than $40 \mathrm{kt}$ as APC coring approached refusal, but Core $25 \mathrm{H}$ was taken before overpull reached 90 kips and vessel motion threatened to force suspension of operations. Coring was thus completed at Site 1090, and the drill string and beacon were recovered. The JOIDES Resolution again headed southward at $1230 \mathrm{hr}$ on 31 December. 
Leg 177

Preliminary Report

Page 88

\section{SITE 1091 \\ (Proposed Site TSO-5C)}

Moderate winds from the west-northwest prevailed for the transit to Site 1091 on the western flank of Meteor Rise. The 281-nmi transit was made in $30 \mathrm{hr}$, with an average speed of $9.3 \mathrm{kt}$. The positioning beacon was launched at $1845 \mathrm{hr}$ on 1 January 1998.

\section{Hole 1091A}

Predicted severe weather (other than cold rain showers) failed to develop. Hole 1091A was spudded at $0445 \mathrm{hr}$ on 2 January with the bit positioned at $4369 \mathrm{mbrf}$. The first core recovered $6.9 \mathrm{~m}$ and placed the seafloor depth at $4371.6 \mathrm{mbrf}$. Continuous APC cores were recovered, with cores $3 \mathrm{H}$ and $16 \mathrm{H}$ requiring a second wireline trip when the APC failed to actuate. Orientation began with Core $3 \mathrm{H}$. A growing swell caused increasing pitch and vessel heave while coring was in progress, and a second swell added rolls of up to $7^{\circ}$. For the safety of the drill string, knobby drilling joints were used from Core $17 \mathrm{H}$, which was the first use of knobbies for APC coring in ODP history.

Weather and motion conditions moderated, and the six knobby drilling joints were removed after Core $29 \mathrm{H}$. Four additional cores were taken to $310.9 \mathrm{mbsf}$, when coring was terminated. The APC refusal point had not been reached, as cores were achieving full stroke and the maximum withdrawal overpull had been 60 kips. Most of the scientific objectives had been reached, however, and the forecast of imminent and exceptionally severe weather prompted the decision to pull out of the hole. The seafloor was cleared at $0315 \mathrm{hr}$ on 4 January to end Hole 1091A.

\section{Hole 1091B}

The severe weather did not occur. The vessel was offset $10 \mathrm{~m}$ and the bit was positioned $3 \mathrm{~m}$ higher than it had been for Hole 1091A. Hole 1091B was spudded with the first APC core at $0455 \mathrm{hr}$ on 4 January. Orientation began with Core $4 \mathrm{H}$ but was discontinued after Core $13 \mathrm{H}$ because the paleomagnetic data from Hole 1091A did not warrant the additional operating time. 
By the morning of 5 January, wind gusts were approaching $40 \mathrm{kt}$ and swells exceeded $20 \mathrm{ft}$ in height. The severe heave conditions affected core recovery adversely and seemed to increase the frequency and severity of core liner failures. Coring continued to the target depth of $274 \mathrm{mbsf}$, but recovery fell to about $60 \%$ for the final ten cores.

\section{Hole 1091C}

The rig was offset by $10 \mathrm{~m}$ for a repeat section. A seafloor core was shot from $4372 \mathrm{mbrf}, 3 \mathrm{~m}$ deeper than the original Hole 1091A mudline core. The driller's pressure gauge showed a mechanical actuation of the APC which significantly reduced prospects for a high-quality core and it was requested that the interval be recorded.

\section{Hole 1091D}

Normal actuation was indicated as a new hole was spudded from the same pipe depth (4372 mbrf). The severe weather and motion conditions persisted for the first few hours of coring, but began improving rapidly in the evening hours of 5 January. Core recovery improved with depth and with improving weather conditions. When the target depth of $203 \mathrm{mbsf}$ had been reached, the drill string was again pulled above the seafloor for a final attempt to fill gaps in the upper stratigraphic section.

\section{Hole 1091E}

The vessel was positioned $10 \mathrm{~m}$ north of Hole 1091B and Hole 1093E was spudded at $1440 \mathrm{hr}$ on 6 January. Again the bit depth was 4372 mbrf because an important sediment gap still existed in the uppermost core interval. Environmental operating conditions were favorable as six APC cores were taken to a depth of 51.7 mbsf. However, recovery was again limited to about $61 \%$. Nearly every core experienced some degree of core liner failure, and some of the failures contributed directly to reduced recovery.

Coring operations at Site 1091 were terminated as the allotted operating time expired. The drill string was recovered and the drill ship was underway at $0545 \mathrm{hr}$ on 7 January. 
Leg 177

Preliminary Report

Page 90

\section{SITE 1092 \\ (Proposed Site SubSAT-3B)}

With a tail wind and a low sea state, the transit to Site 1092 on the Meteor Rise, 63 nmi to the northeast of Site 1091, was accomplished with an average speed of $11.6 \mathrm{kt}$. After the positioning approach had been completed and bow thrusters lowered, a positioning beacon was launched at $1145 \mathrm{hr}$ on 7 January.

\section{Hole 1092A}

The drill bit was positioned at 1986 mbrf for the initial core, and an 8-m core established seafloor depth at 1987.5 mbrf. Continuous APC coring continued through Core $20 \mathrm{H}$. Good environmental operating conditions permitted very good core recovery despite several core liner failures, but the weather began to deteriorate as TD was approached.

Withdrawal overpull on Core 19H was $30 \mathrm{kips}$, but Core $20 \mathrm{H}$ (188.5 mbsf TD) could not be pulled free with a force of 100 kips. It was necessary to drill over the core barrel for $5 \mathrm{~m}$ to free it. Vessel heave had increased to nearly $2 \mathrm{~m}$ by that time, and the APC assembly sustained severe damage from the drillover operation. Coring operations were terminated because most scientific objectives and effective APC refusal had been reached.

\section{Hole 1092B}

The ship was offset $10 \mathrm{~m}$ laterally. To achieve stratigraphic overlap, the new hole was spudded with the bit $4 \mathrm{~m}$ higher than for Core 1092A-1H. Core recovery indicated a seafloor depth about $3.5 \mathrm{~m}$ shallower than at Hole 1092A. Weather and motion conditions were less favorable for Hole 1092B, and core recovery and quality were diminished by an increase in core liner failures and other motion-related factors. Overall recovery was good, but there were gaps in the recovered section. The coring depth target was reached with Core $18 \mathrm{H}$ at $168.9 \mathrm{mbsf}$, and the drill string again was withdrawn for a respud. 


\section{Hole 1092C}

Coring began at $2115 \mathrm{hr}$ on 8 January. Results improved with time and depth as the weather abated and vessel-motion conditions improved. The target depth of $165.5 \mathrm{mbsf}$ was reached after 18 cores.

\section{Hole 1092D}

The first three holes at Site 1092 had failed to achieve complete stratigraphic coverage of the section because of lost and disturbed cores at a relatively shallow depth. Thus, a fourth hole was requested to cover the interval equivalent to $36-64.5$ mbsf in Hole 1092C.

When the bit had been pulled clear of the seafloor, the vessel was offset to a position near the center of the three positions determined for the first three holes. The new positioning offsets were closest to Hole 1092B and, therefore, the seafloor depth of that hole was assumed. Hole 1092D was spudded at $0840 \mathrm{hr}$ on 9 January and the hole was drilled ahead to $36.4 \mathrm{mbsf}$. From there, three consecutive APC cores were taken to a TD of $64.9 \mathrm{mbsf}$. Coring results were good and the scientific objectives of the site were achieved.

The drill string was recovered, and the bottom-hole assembly (BHA) connections were inspected magnetically for cracks. The vessel was under way at $1818 \mathrm{hr}$ on 9 January.

\section{SITE 1093}

\section{(Proposed Site TSO-6A)}

Winds were light to moderate for the 220-nmi transit to Site 1093 on the northern flank of Shona Ridge to the south. Winds changed direction from northwesterly to southwesterly during the morning of 10 January. Thus, the second half of the transit was slower, but an average speed of $9.9 \mathrm{kt}$ was achieved. The drill site was approached by GPS coordinates, and a beacon was launched at $1624 \mathrm{hr}$ on 10 January. 
Leg 177

Preliminary Report

Page 92

\section{Hole 1093A}

Hole 1093A was spudded with a seafloor APC core at $2355 \mathrm{hr}$ on 10 January. An 8.5-m core set the seafloor depth at 3635.0 mbrf. Continuous cores were taken with orientation beginning on Core $4 \mathrm{H}$. APCT measurements started with Core $4 \mathrm{H}$ and continued through Core $16 \mathrm{H}$. Core recovery was excellent, with an average of $103 \%$ achieved through APC refusal. Withdrawal of the corer required 50-60 kips beginning with Core $23 \mathrm{H}$. Cores $25 \mathrm{H}$ and $26 \mathrm{H}$ failed to stroke completely in the stiffening sediments, and a severe plastic liner failure necessitated pumping Core $25 \mathrm{H}$ from the inner core barrel. Those failures were considered to signal effective refusal depth for the APC, and coring switched to the XCB mode.

The first three XCB cores recovered low-quality core with only $38 \%$ recovery. At the request of the scientific party, an additional APC core was attempted which had incomplete stroke and recovered $3.9 \mathrm{~m}$ of core of partly excellent and partly disturbed recovery and a badly broken liner. An additional four XCB attempts recovered only pebbles of ice-rafted debris in the core catchers. Though weather and motion conditions were deteriorating at the time, the inability to recover core was attributed to the properties of the diatomaceous sediment. Coring attempts were abandoned at 309.4 mbsf after Core 34X. The bit was pulled clear of the seafloor at $1245 \mathrm{hr}$ on 12 January.

\section{Hole 1093B}

In an attempt to recover the seafloor interface, the bit was positioned $4 \mathrm{~m}$ higher for the new spud than it had been for Core 1093A-1H. The first core attempt produced no sediment, and only plastic fragments from a break at the top of the core liner were found in the core catcher. A second coring attempt from $9.5 \mathrm{~m}$ deeper recovered $7.1 \mathrm{~m}$ of sediment and was designated Core 1093B-1H. (Later hole-to-hole correlation revealed that several meters apparently had been penetrated and lost from the first core barrel.)

Vessel heave, which had continued to build after the earlier strong winds, died off and reached $11 \mathrm{ft}$ around the time of spudding. It decreased as coring continued, however, and good results again were achieved in favorable operating conditions. Cores were oriented beginning with Core 
Leg 177

Preliminary Report

Page 93

4H. APC refusal was declared when Core $24 \mathrm{H}$ failed to achieve complete stroke, and the drill string was raised for the third hole.

\section{Hole 1093C}

To maintain a stratigraphic overlap, the mudline APC core was shot from $2 \mathrm{~m}$ deeper than the initial attempt at Hole 1093B. Again only a trace of the soft seafloor sediment was recovered, and the interface was missed. The second core recovered $8.0 \mathrm{~m}$ of sediment and was designated Core $1093 \mathrm{C}-1 \mathrm{H}$. Core orientation began with Core $3 \mathrm{H}$.

Routine inspection of the aft coring line revealed several broken wires just above the ropesocket. The line was removed from service for reheading. During the attempt to put the forward sinker bar into the drill string, the upper wraps of line on the winch drum became fouled because the spooling of the wire was excessively loose. Efforts to correct the situation resulted in a severe kink in the wire. It was then necessary to cut and rehead the aft wire and put it back into service. A loss of $1.5 \mathrm{hr}$ of operating time resulted.

Winds were light, but a moderate swell persisted as continuous cores were taken over the interval covered by the preceding two holes. The swell built rapidly in the early morning hours of 14 January and was joined by a large cross swell. Vessel heave increased to as much as $12 \mathrm{ft}$ and core recovery and quality dropped concurrently. Average recovery for Cores $13 \mathrm{H}-18 \mathrm{H}$ was $42 \%$. A knobby drilling joint was picked up for Core $18 \mathrm{H}$ and the situation was evaluated as the operational roll limit was reached and pitch and heave limits were approached. At $169.5 \mathrm{mbsf}$, coring operations were terminated and the drill string was pulled above the seafloor to wait out the swell and weather conditions, which continued to deteriorate. Knobby drilling joints again were located at the top of the drill string to handle bending stresses at the guide horn, and the drill string was hung off with the bit suspended at 3527 mbrf.

\section{Hole 1093D}

Swell and weather conditions changed little during the afternoon and night hours, except that the cross swell gradually died out and the amount of vessel roll decreased. One set of swells of 
Leg 177

Preliminary Report

Page 94

25-30 ft persisted into the morning of 15 January. When the swell height had decreased slightly and roll and pitch were within operating limits, conditions were considered safe for rig floor personnel to handle pipe. Heave remained too high for successful coring, but operations resumed at $0500 \mathrm{hr}$, after $15.25 \mathrm{hr}$ of downtime, in the hope that conditions would continue to improve. The drill string was run back to the seafloor and Hole 1093D was spudded at 0640. The hole was drilled to 136 mbsf, where continuous oriented APC coring began.

Vessel heave continued to have an adverse effect on core recovery into the afternoon of the first day. Recovery improved with environmental conditions, only to decrease as an incomplete stroke occurred with Core $12 \mathrm{H}$ at about $245 \mathrm{mbsf}$. Because of the inability to recover that material with the XCB system in Hole 1093A, coring continued with the APC and $9.5 \mathrm{~m}$ advance between cores through Core $18 \mathrm{H}$ (307 mbsf). Core recovery was mostly insignificant and severe liner failures occurred.

The coring mode then was switched to $\mathrm{XCB}$ and recovery was nil, as expected. Only pebbles of ice-rafted material were retained in the core catchers of the next three cores. As the seismic record and drilling parameters suggested that a different, softer sediment unit might have been reached, another APC core (Core $22 \mathrm{H}$ ) was attempted. Recovery was $1.2 \mathrm{~m}$ of soft sediment from 329 mbsf, which was sufficient for age dating. XCB coring continued, without recovery, through Core 26X. During that period, recurrent high circulating pressures indicated that jets in the main bit were becoming plugged with the small pebbles that were plentiful at the bottom of the hole (as evidenced by recovery on the top of each core). Most of the jets apparently were cleared by pumping core barrel $27 \mathrm{X}$ into place at a very high rate (100 strokes per minute [spm]), and near-normal circulating pressure was regained. Core $27 \mathrm{X}$ recovered $6 \mathrm{~m}$, but a total of only $4.3 \mathrm{~m}$ were recovered from the next five cores despite normal operating parameters.

The nature of the sediment then changed to a clay-rich material, and high recovery rates were enjoyed over the next $70 \mathrm{~m}$ to a depth of $492 \mathrm{mbsf}$. A return to diatomaceous ooze, however, brought the return of recovery problems, and clay-rich streaks were recovered selectively to 557 mbsf, with average recovery of only $\sim 11 \%$. At that depth, streaks of hard drilling, interbedded 
with softer material, were encountered, slowing the rate of penetration sharply with no significant increase in core recovery.

In addition to increasing signs of incomplete hole cleaning, bit plugging problems returned. Extremely high circulating pressure upon the landing of core barrel 49X indicated nearly complete blockage of the bit jet channels. Torque and weight indications also showed about 1.5 $\mathrm{m}$ of hard fill in the hole. Pressure was too high to attempt cutting a core, and the core barrel was retrieved. A mud pill was pumped, followed by a fresh core barrel at $100 \mathrm{spm}$. The effort was successful in reducing circulating pressure to an acceptable level, and another slow core was cut. The landing of core barrel 50X was a repeat of the previous attempt. The bit again was plugged when the barrel landed. As preparations were being made to retrieve the barrel, partial circulation was regained. Low rate of penetration (ROP) and core recovery had prompted the decision to terminate coring, but Core 50X was cut while a 50-bbl mud sweep was circulated to clean the hole for logging. The ROP was slightly higher, but only $50 \mathrm{~cm}$ of hard cherty mudstone was recovered.

A go-devil was pumped through the drill string to latch open the lockable float valve, and the drill string was pulled to logging depth. No drag was encountered on the up-trip, so a wiper trip was not considered necessary. Knobby joints were picked up, and the bit was placed at 3722 mbrf for the logging operation.

The triple-combination logging tool was the first deployed. The tool went to within $7.5 \mathrm{~m}$ of total depth after meeting minor resistance in the upper section of the hole. Weather and sea conditions were excellent, and a technically valid log was recorded. Its quality and usefulness were degraded by the large, washed-out hole diameter and extremely high porosity of the sediments.

The second logging run was made with the geological high-sensitivity magnetic tool (GHMT) string. The light-weight tool reached $581 \mathrm{mbsf}$, and a good magnetic susceptibility log was obtained over the entire hole interval. Because of the unfavorable hole conditions, the planned 
Leg 177

Preliminary Report

Page 96

Formation MicroScanner log was not run. Logging operations were completed and the wireline sheaves rigged down by $2145 \mathrm{hr}$ on 18 January.

The knobby joints were laid down, and the drill string was pulled clear of the seafloor for the final coring attempts at the site.

\section{Hole 1093E}

An additional attempt to obtain a seafloor interface core had been requested, as the uppermost sediments apparently had not yet been recovered at the site. The vessel was offset back to the coordinates of Hole 1093B, and the bit was positioned at 3629.5 mbrf. As vessel motion conditions were minimal, a single APC shearpin was used to reduce the impact of actuation. The APC appeared to fire at a relatively low pressure as expected, but was recovered with the shearpin intact. The APC assembly was sent down for a second attempt at the same depth. Again there was difficulty in actuating the APC, with anomalous pressure indications. The corer was recovered in the stroked out condition, but with a broken liner and no trace of sediment (a "water core") indicating a seafloor depth below 3639 mbrf and well below the 3635 mbrf indicated by Core 1093A-1H. A third attempt was made from $4 \mathrm{~m}$ deeper. The results were a broken core liner and traces of mud on the core catcher. Efforts to recover a mudline core were abandoned.

Hole $1093 \mathrm{E}$ was then officially spudded as the bit was "washed" to $4 \mathrm{~m}$ below the apparent seafloor depth of Hole 1093A and an APC core was taken to fill a gap in the composite section of the site. A split liner with $6.6 \mathrm{~m}$ of sediment was recovered. After an additional washdown to 33 mbsf, a second core was taken to fill another gap and to end the coring program at Site 1093. During recovery of the core, the coring line was coated for preservation, as the remaining site was in much shallower water. Core recovery was only $5.0 \mathrm{~m}$, and the liner again had failed.

The drill string was pulled above the seafloor and preparations began for a scheduled slip and cut of the drilling line. 
Leg 177

Preliminary Report

Page 97

\section{Hole 1093F}

Review of the coring results by the scientific party resulted in concerns that a gap still existed in the section, but this could not be confirmed without results from the multisensor track core logging. The rig operation was halted for half an hour while it was confirmed that one additional core was needed.

Hole $1093 \mathrm{~F}$ was spudded at $0640 \mathrm{hr}$ on 19 January and was drilled to $34 \mathrm{mbsf}$ (inferred from Hole 1093A). A final APC core was shot from that depth, and $6.2 \mathrm{~m}$ of sediment was recovered. The coring line was coated again on the retrieval trip.

When the bit had been pulled to about $75 \mathrm{~m}$ above the seafloor, the cut-and-slip operation was completed. During the ensuing pipe trip, both wind and swell had increased greatly, and most of the trip was made in steady rain with a wind chill factor of $8^{\circ} \mathrm{F}$. The JOIDES Resolution departed the site at $1800 \mathrm{hr}$ on 19 January.

\section{SITE 1094 \\ (Proposed Site TSO-7C)}

The voyage to Site 1094 north of Bouvet Island began with the wind gusting to $38 \mathrm{kt}$ and seas and swell nearly at right angles to the ship's track. Rolling heavily, the vessel made only about 6 $\mathrm{kt}$ on her southerly course for the remainder of the evening. At $2330 \mathrm{hr}$, it was necessary to slow the shafts and to alter course because of excessive vessel motion.

At $0030 \mathrm{hr}$ on 20 January, the drilling crew reported that the forward retaining pin and the two safety slings of the lower guide horn (LGH) in the moonpool had broken and that the port half of the LGH was swinging free about its hinges on the aft pin. The ship was slowed to $\sim 2 \mathrm{kt}$ in the heavy weather while attempts were made to restrain the LGH. These attempts were unsuccessful, and speed was increased to $5 \mathrm{kt}$ in the direction of the drill site, which was still about $150 \mathrm{nmi}$ away. At $0315 \mathrm{hr}$, the aft pin failed just above the water line and allowed the upper part of the 
Leg 177

Preliminary Report

Page 98

unrestrained section of the LGH to move forward and outboard until it came to rest against the wall of the moonpool. The port LGH section (of undetermined length, later determined to be complete) remained attached to the starboard half at a lower corner by a section of the aft retaining pin. The displaced portion was securely wedged across the moonpool and remained in place as the ship proceeded at full speed toward the drill site in rapidly improving weather.

Visual inspection indicated that the center of the moonpool was unobstructed and that drilling operations were feasible to the extent allowed by the 20 - $\mathrm{ft}$ reduction of the port LGH. Operations thus continued according to plan, and a positioning beacon was launched at $2000 \mathrm{hr}$ on 20 January.

\section{Hole 1094A}

While the vessel was stabilizing its position on the beacon, a stand of drill pipe was picked up and run through the moonpool to confirm that the center well was unobstructed. The signal from the positioning beacon was weak and considered unreliable, so the backup beacon was launched at $2050 \mathrm{hr}$ while the BHA was being assembled.

Weather and swell conditions improved dramatically to nearly flat calm as spud time approached, allaying concerns about stricter operating limits on vessel motion that were expected from ODP engineers. The pipe trip was slowed somewhat because stands of drill pipe had shifted on the piperack during the rough weather and had to be repositioned for handling by the automatic racker.

At $0408 \mathrm{hr}$ on 21 January, Hole 1094A was spudded with an APC core from 2814 mbrf. The initial 4.6-m core set the seafloor depth at 2818.9 mbrf. APCT temperature readings were taken with Cores $1 \mathrm{H}$ (for bottom water temperature), $4 \mathrm{H}, 6 \mathrm{H}, 8 \mathrm{H}, 10 \mathrm{H}, 12 \mathrm{H}, 14 \mathrm{H}$, and $16 \mathrm{H}$. The majority of cores were oriented azimuthally as the one remaining operational instrument permitted. Coring results were affected adversely by the accumulation of ice-rafted debris in the hole and by persistent core liner failures. (Nearly $100 \%$ of the liners failed in some manner.) 
Core $18 \mathrm{H}$ indicated incomplete stroke and produced no recovery. A 3-m interval was drilled in case the refusal was due to a thin hard stratum. Core $19 \mathrm{H}$ also had incomplete stroke but recovered $8 \mathrm{~m}$ of core which apparently was a stack of two sections resulting from two successive stabs with the corer. As APC refusal apparently had been reached, a Davis-Villinger temperature probe run was made to complete the temperature gradient profile.

One additional attempt was made to obtain an APC core before abandoning the hole. Several attempts to actuate the corer were unsuccessful and the APC was recovered with the shearpins intact. Coring in Hole 1094A was discontinued at the request of the scientific party and the drill string was withdrawn from the hole.

\section{Hole 1094B}

The rig was offset $10 \mathrm{~m}$, and Hole 1094B was spudded with a seafloor APC core at $0015 \mathrm{hr}$ on 22 January. Core recovery provided close agreement with the seafloor depth of Hole 1094A.

The anticipated guidelines for coring with a damaged LGH were received while Hole 1094B was being cored. Roll and pitch limits were reduced, as expected, and the use of knobby drilling joints was mandated for all drilling/coring operations. The knobbies were put into service beginning with Core $4 \mathrm{H}$.

Cores $1 \mathrm{H}$ and $2 \mathrm{H}$ gave essentially full recovery, but recovery was poor in Cores $3 \mathrm{H}$ and $4 \mathrm{H}$. All four cores gave pressure indications of incomplete stroke. Because of the good results in Hole 1094A, the presence of ice-rafted debris in the hole was blamed for the unsatisfactory performance in Hole 1094B. To make the best use of remaining operating time, the decision was made to pull clear of the seafloor, offset $10 \mathrm{~m}$ to the opposite side of Hole 1094A, and start over.

\section{Hole 1094C}

A third successful mudline core was collected with Core 1094C-1H, shot at $0443 \mathrm{hr}$ from 2818 mbrf. All three seafloor depths agreed within $1 \mathrm{~m}$. Problems with APC performance again were experienced as eight cores were attempted and six of them gave pressure indications of 
Leg 177

Preliminary Report

Page 100

incomplete stroke. The two cores that indicated full stroke had no recovery. After Core $8 \mathrm{H}$, which recovered $1.3 \mathrm{~m}$ of sediment, the drill struck hard material after reaming $7.2 \mathrm{~m}$ toward the next core point. No measurable penetration was made after 20 min of rotation. Again the coring problems were attributed to ice-rafted material in the sediment, with the final hard streak interpreted as a boulder. Coring attempts were abandoned, and the bit was raised above the seafloor.

\section{Hole 1094D}

The ship was offset about $20 \mathrm{~m}$ to the northwest of the coordinates of the earlier holes. The hole was drilled to $19.1 \mathrm{~m}$ below inferred seafloor depth before the APC was deployed. Continuous APC cores $1 \mathrm{H}$ through $13 \mathrm{H}$ were taken to $142.6 \mathrm{mbsf}$ before it was necessary to replace the knobby joints with standard drill pipe. When the bit reached TD following the 2-hr short trip, about $1.5 \mathrm{~m}$ of fill were found in the hole. A mud flush was pumped concurrently with Core $14 \mathrm{H}$, following the trip.

At the time Core $16 \mathrm{H}$ was being recovered from $171.1 \mathrm{mbsf}(0215 \mathrm{hr}$ on January 23$)$ a partial load shedding to the ship's dynamic positioning (DP) system occurred, presumably the result of an unexpected drift-off ( $2 \%$ yellow alarm) in relatively calm seas and moderately windy weather (30-40 kt gusts). Within 3 min, position was recovered to 1\%. The load shed in conjunction with exceeding operations limits ( $4^{\circ}$ pitch or roll) led to the decision by the Operations Manager to terminate the scientific drilling operations of Leg 177. Coring at Site 1094 was therefore terminated about 1.5 days ahead of schedule.

When the drill string had cleared the seafloor, weather and motion conditions were essentially unchanged, and it was deemed safe to run the coring line back down the pipe so that it could be sprayed with protective coating while being retrieved. The drill string then was tripped during improving weather conditions, and the BHA was broken down and stored for transit. The bit arrived on deck at $1145 \mathrm{hr}$ on 23 January. 
An extensive effort then was made to secure the broken LGH-half in the moonpool prior to the transit to Punta Arenas. A retaining frame consisting of two 17-ft I-beams in an open cross configuration had been fabricated on the rig. The frame, complete with padeyes and heavy slings, was keelhauled over the side of the vessel (the moonpool doors could not be opened) and suspended from the main traveling block by cable slings through the center well of the moonpool. The block then was raised to engage the bottom of the LGH-half with the frame. After several attempts, the frame was determined to be supporting the LGH. Efforts to lift and realign the LGH-half were unsuccessful, but a tension of 30 kips on the slings, in addition to the attachment of the lower corner at the locking pin, seemed to stabilize the assembly and prevent motion relative to the moonpool wall and the starboard half of the LGH. That appeared to be the best possible preparation for the long, rough transit ahead, and the rig floor was secured with the driller at his station to monitor the tension on the support frame.

The vessel had remained in full DP mode for the securing operation, and an additional $3 \mathrm{hr}$ were required to recover the positioning beacons, house the hydrophones, raise the thrusters, and do the protective maintenance for transit that normally is done during the final pipe trip. The vessel departed Site 1094 at $1845 \mathrm{hr}$ on 23 January.

\section{TRANSIT FROM SITE 1094 TO PUNTA ARENAS}

The ship had been under way less than $2 \mathrm{hr}$ when the driller reported a loss of tension on the damaged LGH. The ship was slowed, and investigation revealed that the forward locking pin had failed and that the port LGH-half was moving unrestrained in the moonpool, supported only by the cross frame at its base. The surge produced by moderate swells was causing too much movement of the massive (22-ton) structure for it to be restrained. With forward motion of the ship, the movement became so violent that serious damage to the moonpool appeared imminent. For the safety of the vessel, the crew had no choice but to lower the LGH until it fell free. The retaining cross was also released, and the vessel continued at full speed into deteriorating weather. 


\section{OCEAN DRILLING PROGRAM \\ OPERATIONS RESUME \\ LEG 177}

Total Days (10 December 97 to 5 February 98)

58.6

Total Days in Port

5.1

Total Days Under Way

20.3

Total Days on Site

33.1

Drilling

$\underline{\text { days }}$

Tripping Time

0.28

Logging/Downhole Science

6.43

Mechanical Repair Time (Contractor)

W.O.W.

Coring

ODP Equipment Downtime

Other

Stuck Pipe and Hole Trouble

Total Distance Traveled (nautical miles)

Average Speed Transit (knots):

Number of Sites

Number of Holes

Number of Cores Attempted

Total Interval Cored (m)

Total Core Recovery (m)

$\%$ Core Recovery

Total Interval Drilled (m)

Total Penetration

Maximum Penetration (m)

Minimum Penetration (m)

Maximum Water Depth (m from drilling datum) 
OCEAN DRILLING PROGRAM

SITE SUMMARY

LEG 177

\begin{tabular}{|c|c|c|c|c|c|c|c|c|c|c|c|}
\hline HOLE & LATITUDE & LONGITUDE & $\begin{array}{l}\text { WATER } \\
\text { DEPTH } \\
\text { (mbrf) }\end{array}$ & $\begin{array}{l}\text { NUMBER } \\
\text { OF CORES }\end{array}$ & $\begin{array}{l}\text { INTERVAL } \\
\text { CORED } \\
\text { (meters) }\end{array}$ & $\begin{array}{c}\text { CORE } \\
\text { RECOVERED } \\
\text { (meters) }\end{array}$ & $\begin{array}{c}\text { PERCENT } \\
\text { RECOVERED } \\
\text { (percent) }\end{array}$ & $\begin{array}{c}\text { DRILLED } \\
\text { (meters) }\end{array}$ & $\begin{array}{c}\text { TOTAL } \\
\text { PENETRATION } \\
\text { (meters) }\end{array}$ & $\begin{array}{l}\text { TIME ON } \\
\text { HOLE } \\
\text { (hours) }\end{array}$ & $\begin{array}{l}\text { TIME ON } \\
\text { SITE } \\
\text { (days) }\end{array}$ \\
\hline $1088 \mathrm{~A}$ & $41^{\circ} 8.163 ' \mathrm{~S}$ & $13^{\circ} 33.770^{\prime} \mathrm{E}$ & 2093.0 & 1 & 9.50 & 9.94 & $104.6 \%$ & 0.0 & 9.50 & 12.00 & 0.50 \\
\hline 1088B & $41^{\circ} 8.163 ' \mathrm{~S}$ & $13^{\circ} 33.770^{\prime} \mathrm{E}$ & 2092.0 & 14 & 129.00 & 125.55 & $97.3 \%$ & 0.0 & 129.00 & 13.50 & 0.56 \\
\hline \multirow[t]{2}{*}{$1088 \mathrm{C}$} & $41^{\circ} 8.165^{\prime} \mathrm{S}$ & $13^{\circ} 33.772^{\prime} \mathrm{E}$ & 2093.7 & 13 & 114.90 & 93.86 & $81.7 \%$ & 118.5 & 233.40 & 23.25 & 0.97 \\
\hline & & \multicolumn{2}{|c|}{1088 SITE TOTALS: } & 28 & 253.40 & 229.35 & $90.5 \%$ & 118.5 & 371.90 & 48.75 & 2.03 \\
\hline $1089 \mathrm{~A}$ & $40^{\circ} 56.187^{\prime} \mathrm{S}$ & $9^{\circ} 53.645^{\prime} \mathrm{E}$ & 4630.2 & 23 & 216.30 & 149.64 & $69.2 \%$ & 0.0 & 216.30 & 45.00 & 1.88 \\
\hline 1089B & $40^{\circ} 56.182^{\prime} \mathrm{S}$ & $9^{\circ} 53.640^{\prime} \mathrm{E}$ & 4634.7 & 29 & 264.90 & 246.62 & $93.1 \%$ & 0.0 & 264.90 & 33.50 & 1.40 \\
\hline $1089 \mathrm{C}$ & $40^{\circ} 56.169^{\prime} \mathrm{S}$ & $9^{\circ} 53.637^{\prime} \mathrm{E}$ & 4632.1 & 21 & 192.40 & 160.29 & $83.3 \%$ & 2.0 & 194.40 & 27.50 & 1.15 \\
\hline \multirow[t]{2}{*}{ 1089D } & $40^{\circ} 56.187^{\prime} \mathrm{S}$ & $9^{\circ} 53.632^{\prime} \mathrm{E}$ & 4628.5 & 13 & 118.00 & 119.36 & $101.2 \%$ & 0.0 & 118.00 & 27.25 & 1.14 \\
\hline & & \multicolumn{2}{|c|}{1089 SITE TOTALS: } & 86 & 791.60 & 675.91 & $85.4 \%$ & 2.0 & 793.60 & 133.25 & 5.55 \\
\hline $1090 \mathrm{~A}$ & $42^{\circ} 54.821^{\prime} \mathrm{S}$ & $8^{\circ} 53.984^{\prime} \mathrm{E}$ & 3709.5 & 1 & 7.00 & 7.02 & $100.3 \%$ & 0.0 & 7.00 & 22.00 & 0.92 \\
\hline 1090B & $42^{\circ} 54.821^{\prime} \mathrm{S}$ & $8^{\circ} 53.984^{\prime} \mathrm{E}$ & 3710.3 & 43 & 397.50 & 373.23 & $93.9 \%$ & 0.0 & 397.50 & 47.75 & 1.99 \\
\hline $1090 \mathrm{C}$ & $42^{\circ} 54.812^{\prime} \mathrm{S}$ & $8^{\circ} 53.990^{\prime} \mathrm{E}$ & 3714.7 & 8 & 69.30 & 63.78 & $92.0 \%$ & 0.0 & 69.30 & 8.50 & 0.35 \\
\hline $1090 \mathrm{D}$ & $42^{\circ} 54.814^{\prime} \mathrm{S}$ & $8^{\circ} 53.998^{\prime} \mathrm{E}$ & 3713.1 & 24 & 225.90 & 213.64 & $94.6 \%$ & 0.0 & 225.90 & 25.50 & 1.06 \\
\hline \multirow[t]{2}{*}{$1090 \mathrm{E}$} & $42^{\circ} 54.818^{\prime} \mathrm{S}$ & $8^{\circ} 53.994^{\prime} \mathrm{E}$ & 3715.3 & 25 & 236.70 & 217.26 & $91.8 \%$ & 0.0 & 236.70 & 35.50 & 1.48 \\
\hline & & \multicolumn{2}{|c|}{1090 SITE TOTALS: } & 101 & 936.40 & 874.93 & $93.4 \%$ & 0.0 & 936.40 & 139.25 & 5.80 \\
\hline $1091 \mathrm{~A}$ & $47^{\circ} 5.681 ' \mathrm{~S}$ & $5^{\circ} 55.120^{\prime} \mathrm{E}$ & 4371.6 & 33 & 310.90 & 279.77 & $90.0 \%$ & 0.0 & 310.90 & 56.50 & 2.35 \\
\hline 1091B & $47^{\circ} 5.682^{\prime} \mathrm{S}$ & $5^{\circ} 55.125^{\prime} \mathrm{E}$ & 4367.7 & 29 & 273.80 & 203.52 & $74.3 \%$ & 0.0 & 273.80 & 32.25 & 1.34 \\
\hline $1091 \mathrm{C}$ & $47^{\circ} 5.688^{\prime} \mathrm{S}$ & $5^{\circ} 55.164^{\prime} \mathrm{E}$ & 4377.5 & 1 & 4.00 & 3.95 & $98.8 \%$ & 0.0 & 4.00 & 1.25 & 0.05 \\
\hline 1091D & $47^{\circ} 5.688^{\prime} \mathrm{S}$ & $5^{\circ} 55.164^{\prime} \mathrm{E}$ & 4377.9 & 22 & 203.10 & 165.18 & $81.3 \%$ & 0.0 & 203.10 & 24.50 & 1.02 \\
\hline \multirow[t]{2}{*}{$1091 \mathrm{E}$} & $47^{\circ} 5.695 ' S$ & $5^{\circ} 55.152^{\prime} \mathrm{E}$ & 4377.3 & 6 & 51.70 & 31.49 & $60.9 \%$ & 0.0 & 51.70 & 16.50 & 0.69 \\
\hline & & \multicolumn{2}{|c|}{1091 SITE TOTALS: } & 91 & 843.50 & 683.91 & $81.1 \%$ & 0.0 & 843.50 & 131.00 & 5.46 \\
\hline $1092 \mathrm{~A}$ & $46^{\circ} 24.708^{\prime} \mathrm{S}$ & $7^{\circ} 4.792^{\prime} \mathrm{E}$ & 1987.5 & 20 & 188.50 & 181.94 & $96.5 \%$ & 0.0 & 188.50 & 20.00 & 0.83 \\
\hline 1092B & $46^{\circ} 24.705^{\prime} \mathrm{S}$ & $7^{\circ} 4.794^{\prime} \mathrm{E}$ & 1984.1 & 18 & 168.90 & 144.54 & $85.6 \%$ & 0.0 & 168.90 & 12.25 & 0.51 \\
\hline $1092 \mathrm{C}$ & $46^{\circ} 24.697^{\prime} \mathrm{S}$ & $7^{\circ} 4.796^{\prime} \mathrm{E}$ & 1984.5 & 18 & 165.50 & 150.79 & $91.1 \%$ & 0.0 & 165.50 & 12.00 & 0.50 \\
\hline \multirow[t]{2}{*}{$1092 \mathrm{D}$} & $46^{\circ} 24.704^{\prime} \mathrm{S}$ & $7^{\circ} 4.787^{\prime} \mathrm{E}$ & 1984.1 & 3 & 28.50 & 28.28 & $99.2 \%$ & 36.4 & 64.90 & 10.25 & 0.43 \\
\hline & & \multicolumn{2}{|c|}{1092 SITE TOTALS: } & 59 & 551.40 & 505.55 & $91.7 \%$ & 36.4 & $\mathbf{5 8 7 . 8 0}$ & 54.50 & 2.27 \\
\hline
\end{tabular}


OCEAN DRILLING PROGRAM

SITE SUMMARY

LEG 177

\begin{tabular}{|c|c|c|c|c|c|c|c|c|c|c|c|}
\hline HOLE & LATITUDE & LONGITUDE & $\begin{array}{c}\text { WATER } \\
\text { DEPTH } \\
\text { (mbrf) }\end{array}$ & $\begin{array}{l}\text { NUMBER } \\
\text { OF CORES } \\
\end{array}$ & $\begin{array}{l}\text { INTERVAL } \\
\text { CORED } \\
\text { (meters) }\end{array}$ & $\begin{array}{c}\text { CORE } \\
\text { RECOVERED } \\
\text { (meters) }\end{array}$ & $\begin{array}{c}\text { PERCENT } \\
\text { RECOVERED } \\
\text { (percent) }\end{array}$ & $\begin{array}{c}\text { DRILLED } \\
\text { (meters) }\end{array}$ & $\begin{array}{c}\text { TOTAL } \\
\text { PENETRATION } \\
\text { (meters) }\end{array}$ & $\begin{array}{l}\text { TIME ON } \\
\text { HOLE } \\
\text { (hours) }\end{array}$ & $\begin{array}{l}\text { TIME ON } \\
\text { SITE } \\
\text { (days) }\end{array}$ \\
\hline $1093 \mathrm{~A}$ & $49^{\circ} 58.594 ' \mathrm{~S}$ & $5^{\circ} 51.922^{\prime} \mathrm{E}$ & 3635.0 & 34 & 309.40 & 263.69 & $85.2 \%$ & 0.0 & 309.40 & 44.25 & 1.84 \\
\hline 1093B & $49^{\circ} 58.592^{\prime} \mathrm{S}$ & $5^{\circ} 51.933^{\prime} \mathrm{E}$ & 3641.9 & 24 & 221.80 & 208.98 & $94.2 \%$ & 0.0 & 221.80 & 25.50 & 1.06 \\
\hline $1093 \mathrm{C}$ & $49^{\circ} 58.593 ' \mathrm{~S}$ & $5^{\circ} 51.946^{\prime} \mathrm{E}$ & 3643.0 & 18 & 169.50 & 119.46 & $70.5 \%$ & 0.0 & 169.50 & 23.50 & 0.98 \\
\hline 1093D & $49^{\circ} 58.591 ' \mathrm{~S}$ & $5^{\circ} 51.934^{\prime} \mathrm{E}$ & 3635.0 & 50 & 461.70 & 160.43 & $34.7 \%$ & 136.0 & 597.70 & 104.50 & 4.35 \\
\hline $1093 \mathrm{E}$ & $49^{\circ} 58.578^{\prime} \mathrm{S}$ & $5^{\circ} 51.933^{\prime} \mathrm{E}$ & 3635.0 & 2 & 19.00 & 11.54 & $60.7 \%$ & 23.5 & 42.50 & 7.75 & 0.32 \\
\hline \multirow[t]{2}{*}{$1093 \mathrm{~F}$} & $49^{\circ} 58.578^{\prime} \mathrm{S}$ & $5^{\circ} 51.933^{\prime} \mathrm{E}$ & 3635.0 & 1 & 9.50 & 6.24 & $65.7 \%$ & 34.0 & 43.50 & 12.00 & 0.50 \\
\hline & & \multicolumn{2}{|c|}{1093 SITE TOTALS: } & 129 & 1190.90 & 770.34 & $64.7 \%$ & 193.5 & 1384.4 & 217.50 & 9.06 \\
\hline $1094 \mathrm{~A}$ & $53^{\circ} 10.815^{\prime} \mathrm{S}$ & $5^{\circ} 7.826^{\prime} \mathrm{E}$ & 2818.9 & 19 & 158.60 & 135.08 & $85.2 \%$ & 1.0 & 159.60 & 27.00 & 1.13 \\
\hline 1094B & $53^{\circ} 10.824^{\prime} \mathrm{S}$ & $5^{\circ} 7.830^{\prime} \mathrm{E}$ & 2818.0 & 4 & 38.00 & 23.58 & $62.1 \%$ & 0.0 & 38.00 & 5.25 & 0.22 \\
\hline $1094 \mathrm{C}$ & $53^{\circ} 10.828^{\prime} \mathrm{S}$ & $5^{\circ} 7.808^{\prime} \mathrm{E}$ & 2818.6 & 8 & 73.10 & 46.64 & $63.8 \%$ & 0.0 & 73.10 & 8.00 & 0.33 \\
\hline \multirow[t]{3}{*}{ 1094D } & $53^{\circ} 10.816 ' \mathrm{~S}$ & $5^{\circ} 7.821^{\prime} \mathrm{E}$ & 2818.9 & 17 & 152.00 & 100.76 & $66.3 \%$ & 19.1 & 171.10 & 30.50 & 1.27 \\
\hline & & \multicolumn{2}{|c|}{1094 SITE TOTALS: } & 48 & 421.70 & 306.06 & $72.6 \%$ & 20.1 & 441.80 & 70.75 & 2.95 \\
\hline & & \multicolumn{2}{|c|}{ LEG 177 TOTALS: } & 542 & 4988.90 & 4046.05 & $81.1 \%$ & 370.5 & 5359.40 & 795.00 & 33.12 \\
\hline
\end{tabular}


TECHNICAL REPORT 
Leg 177

Preliminary Report

Page 106

The technical and logistics personnel aboard the JOIDES Resolution for Leg 177 were

Pattie Baucomb

Jerry Bode

Callie Calitz

Roy Davis

Sandy Dillard

John Eastlund

Burney Hamlin

Jim Ippoliti

Kuro Kuroki

Jaque Ledbetter

Prentis Lund

Erinn McCarty

Dave Morley

Erik Mortgaat

Matt O'Regan

Anne Pimmel

Mas Radsted

Jo Ribbens
Marine Lab Specialist: Core Lab

Marine Lab Specialist: Curator

Marine Electronics Specialist

Marine Lab Specialist: Photographer

Marine Logistics Coordinator

Marine Computer Specialist

Lab Officer

Marine Electronics Specialist

Marine Lab Specialist: Senior Tech/Alo

Marine Lab Specialist: X-ray

Marine Lab Specialist: Core Lab

Marine Lab Specialist: Curator

Marine Computer Specialist

Marine Lab Specialist: Chemistry, Physical Properties

Marine Lab Specialist: Paleomagnetics

Marine Lab Specialist: Chemistry

Marine Lab Specialist: Core Lab

Marine Lab Specialist: Yeoperson 


\section{PORT CALL ACTIVITIES}

Two local Electronic Technician (ET) candidates were hired for a 2-month contract for the leg and were given tours of the facilities and equipment they were expected to support.

Marisat-B hardware was installed in the ship's radio room with the help of Marine Computer Specialist (MCS) Stevens and supervised by Dr. Merrill from ODP. Liquid nitrogen dewars were filled promptly and cold weather jackets were returned from the cleaners. A new Ashtech/GLONASS GPS receiver replaced the one in service in the underway lab which is linked to the Winfrog navigation system. An updated version of the JANUS database was installed with the help of the MCSs who stayed during the port call.

\section{LABORATORY ACTIVITIES}

\section{Chemistry Lab}

While support for the leg science was fairly routine, considerable trouble was encountered with special projects and preparing the lab for the coming leg. After the CNS oxygen bottle was changed, double nitrogen peaks were noted. After changing more oxygen cylinders and rebuilding a leaky autosampler it was determined that the UltraPure oxygen was contaminated. Logistics personnel were informed.

While trying to improve the reproducability of the Dionex 100 anion values, the computer supporting it failed. This hampered the preparation of a new digital Dionex 120 unit that was to be used during the next leg. Problems with the computer, software, and networks cards for the new unit are being worked on. The Dionex 100 anion values were improved.

Erik Moortgat, the physical properties lab specialist, was trained in and supported the chemistry lab routine. 
Leg 177

Preliminary Report

Page 108

\section{Computer Services}

As we sailed, network availability was lost throughout the bridge deck. Initially the blame was focused on a new version of the Winfrog navigation system but the fault was finally traced to jerked wires in the radio room, a consequence of the Marisat-B installation. This effort also illuminated the fact that the network wiring labels were gone or had never been put in place when the wires were run. This problem was corrected. Later in the cruise, one small logging file was apparently sent successfully via the Marisat-B transmitter.

Network, server, and CC:mail support consumed a good part of the specialists' time. While things worked well for many, there were a few troublesome areas.

This was a Macintosh computer preference leg and three major difficulties hampered these users. Some could not save Microsoft programs to a server, others were Canvas users who needed/preferred different incompatible versions and, finally, there was network or backup software that subtlety corrupted the Macontosh programs available on the servers.

Corruption in the VAX camp took several days to overcome and reminded everyone how vulnerable the MATMAN and shipping programs are. The effort to transfer these programs to FoxPro is scheduled to continue during the next leg.

Two of the projects initiated this leg included sorting out the many PCs and Macs that are going out of warranty and putting them on the DEC service contract, and preparing some shipboard HELP files for inclusion on the local WEB page.

\section{Core Lab}

High-resolution sampling using the multisensor track (MST) and the Oregon State University split-core analysis track (OSU-SCAT) resulted in occasional backlogs of twenties of cores. It was sometimes necessary to switch logging to cores from a different hole (out of order logging) to allow real-time correlation control and optimized coring depth offsets for the construction of 
composite sections. The OSU-SCAT was located on the outboard wall of the core lab, reducing the table space available for the science staff.

The high incidence of liner failure made core processing on the catwalk more tedious and time consuming.

Heavy-duty bar-code and label printers replaced lighter duty models that were prone to break printing ribbons. The printer locations were modified somewhat to accommodate the significantly larger size of the printer.

\section{Curation}

An objective of this leg was to generate a plan for deferred high-resolution sampling, based on the shipboard physical measurements. This plan made use of composite records from multiple holes at each site and of the results of processing the shipboard paleontology samples. Work on the plans and strategy continued until docking. Guidance will be in place before the sampling in Germany takes place.

For reasons yet unclear, there was a $47 \%$ rate of failure in the core liners used during this cruise, from a few holes or dents to complete fractal fracturing. This resulted in extra time on the catwalk repairing the damaged sections and exhausted the supply of patching material. Soupy sediments in the top sections complicated this issue.

The 606 boxes of cores collected during this leg will be transported to the Bremen Repository.

\section{Downhole Tools Support}

The Adara temperature tools was deployed 24 times with 22 good runs. The Davis-Villiger temperature probe (DVTP) was deployed three times and returned good data on each occasion. Quality of the data was hampered by rough sea states during the measurements, but temperature gradients could be generated anyhow albeit with larger error margins than usual. 
Leg 177

Preliminary Report

Page 110

\section{Electronics Support}

The new hires became familiar with much of the equipment and helped diagnose and fix problems with the bridge-deck network wiring. Xerox service in Cape Town contributed to good service from both of the copiers.

\section{Magnetics Lab}

Problems with the Compumotor power supply interrupted data acqisition for a few hours in the middle of the leg. One Tensor toole failed and the second was impaired enough that no data were collected on one site.

\section{Paleontology Lab}

The Paleontology laboratory was heavily utilized during this leg by five paleontologists and a sedimentologist that used the lab to prepare XRD samples. Supplies were adequate and few problems were mentioned. The $21 \mathrm{~K}$ Marathon centrifuge will be returned for repair. The sieve inventory was updated.

\section{Physical Properties}

The lab received reduced attention (few hours a day) by the lab specialist because he was being trained and helped in the chemistry lab as well. Several problems with data acquisition ( $P$-wave logger [PWL], $P$-wave on split cores [PWS3], natural gamma ray [NGR]) and data upload (NGR, moisture and density [MAD], PWS3] were noticed by the scientists, sometimes quite late when they were writing their reports. Some of the problems could be fixed ad-hoc while others remain for Leg 178.

Control measurements are still not measured (for the MST) and/or uploaded (for MAD) on a routine basis. This makes it hard to identify problems early and impossible to correct data later.

The OSU-SCAT produced the bulk of the diffuse reflectance data on this leg, and also acquired resistivity data using Wenner-type probes inserted 1-2 mm into the core. The Minolta CM-2002 
photospectrometer was mainly used for XCB cores where "blind sampling" with automated sampling increments does not produce reliable data, or when the SCAT could not keep up.

The SCAT was a bit slow because the motion control was not optimized for ODP cores and the time crunch on ODP legs. The distance the instrument is traveling up and down could be reduced to $\sim 20 \%$ and logging would be at least twice as fast (sampling twice as dense).

\section{Underway/Fantail}

WinFrog version 2.60 navigation software was installed during the port call with the annotation changes expected. A review done during the initial transit resulted in a critique that was sent to the Pelagos programmer. A revision is expected for the coming port call.

A new Ashtech GPS/GLONASS receiver was installed during port call; the original unit was installed in DP to provide an independent positioning option should the network or beacons fail at the same time. The increased accuracy of the combined positions may contribute to a margin of safety.

\section{X-Ray Lab}

Nearly 400 samples were submitted for XRD bulk analysis. Eight standards provided by a shipboard scientist were also analyzed so that quantitative analysis of opal concentration in the samples could be done onboard. Many of the samples were treated with HCL by a shipboard scientist, who did the drying and grinding as well. The opal standards and a new shareware version of MacDiff (3.0.0) were left for us to use on future legs.

The unit was out of service during one week while a series of problems with the detector, the generator wiring, and the system controller card were diagnosed and repaired. 
Leg 177

Preliminary Report

Page 112

\section{MISCELLANEOUS}

\section{Special Projects}

The new core rack was welded into place during the transit to the first site. The rig mechanics reamed out the position keeping bolt holes and the bolts were lubricated. A custom tool was made to ease the removal of these bolts when the rack arms are to be rotated down. The safety gates around the hatch access location were modified to accommodate the new rack.

A new set of canvas panels with "window" sections was installed on the catwalk to protect the technical staff from wind and weather. The added light and view provided by the flexible clear panels reduced the dark tunnel effect noted on previous installations. Hot water was tapped from the Downhole Measurement laboratory to the core-catcher sink to make that cleaning job more tolerable. The electric heaters installed took the edge off the routine in mid-30s ${ }^{\circ}$ days.

The new motor generator received in Cape Town was welded in place, the wiring was run, and the panels located. The transfer to this regulated power will be done during the Punta Arenas port call. The Cyberex will be removed. 


\section{LEG 177 LABORATORY STATISTICS}

\section{General Statistics:}

Sites: $\quad 7$

Holes: $\quad 38$

Total Penetration: $\quad 5359$

Meters Cored: $\quad 4989$

Meters Recovered: $\quad 4046$

Time on Site (days): $\quad 33.2$

Number of Cores: $\quad 549$

Number of Samples, Total $\quad 10,737$

Chemistry samples $\quad 1,195$

Other samples $\quad 9542$

Number of Core Boxes: $\quad 606$

\section{Samples Analyzed:}

Magnetics Lab

Half section measurements: $\quad 2400$

Discrete measurements: $\quad 0$

Tensor tool holes $\quad 13$

Physical Properties

Index properties: $\quad 1271$

Velocity: $\quad 3349$

Resistivity: $\quad 0$

Thermcon: $\quad$ (TK04)874

MST: $\quad 2862$

Shear Strength: $\quad 0$

Chemistry Lab

Inorganic Carbonates $\left(\mathrm{CaCO}_{3}\right)$ :

Water Chemistry (the suite includes $\mathrm{pH}$, Alkalinity, Sulfate, Chlorinity, Silica, Phosphate, Ammonia, $\mathrm{Ca}, \mathrm{Mg}, \mathrm{P}, \mathrm{Li}$, $\mathrm{Mn}, \mathrm{Fe}, \mathrm{Sr}, \mathrm{Rb})$ :

Head Space gas analysis: $\quad 184$

Pyrolysis Evaluation, Rock-Eval: $\quad 0$

CNS 264

X-ray Lab

XRD:

XRF:

Thin Sections: $\quad 3$

\section{Underway Geophysics (est.)}

Total Transit Nautical Miles: $\quad 4450$

Bathymetry: $\quad 4000$

Magnetics: $\quad 3700$

Seismic: $\quad 0$

$\begin{array}{ll}\text { XBT's Used: } & 0\end{array}$ 